$$
\begin{aligned}
& S H \\
& 348 \\
& . E_{85}
\end{aligned}
$$





\section{2}

U. S. COMMISSION OF FISH AND FISHERIES, JOHN J. BRICE, Commissioner.

\section{A REPORT}

UPON

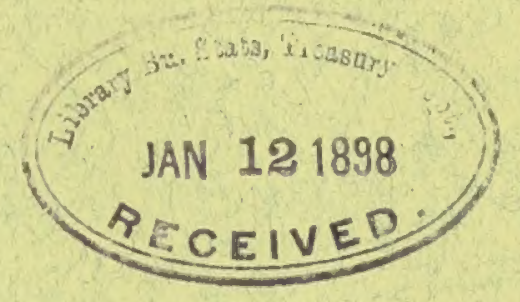

SALMON INVESTIGATIONS IN THE COLUMBIA RIVER BASIN AND ELSEWHERE ON THE PACIFIC COAST IN I8g6.

BY

BARTON WARREN EVERMANN and SETH EUGENE MEEK.

Extracted from U. S. Fish Commission Bulletin for 1897. Article 2, Pages 16 to 84, Plates 1 and 2, and 6 tert figures. Date of pablication, January 6, 1898.

WASHINGTON:

GOVERNMENT PRINTING OFFIOE.

1898. 

U. S. COMMISSION OF FISH AND FISHERIES, JOHN J. BRICE, Commișsioner.

\section{A REPORT}

UPON

\section{SALMON INVESTIGATIONS IN THE COLUMBIA RIVER BASIN AND ELSEWHERE. ON THE PACIFIC COAST IN I8g6.}

BY

BARTON WARREN EVERMANN and SETH EUGENE MEEK.

Extracted from D. S. Fish Oommission Bulletin for 1897. Article 2, Pages 15 to 84, Plates 1 and 2, and 6 tert fgures. Date of publication, January 6, 1898.

WASHINGTON:

GOVERNMENT PRINTING OFFIOE.

1898. 



\title{
2.-A REPORT UPON SALMON INVESTIGATIONS IN THE COLUMBIA RIVER BASIN AND ELSEWHERE ON THE PACIFIC COAST IN 1896.
}

\author{
BY BARTON WARREN EVERMANN AND SETH EUGENE MEEK.
}

During the season of 1896 the United States Fish Commission conducted a number of investigations in Idaho, Washington, and Oregon, having for their general purpose the improvement and extension of the fish-cultural operations of the Commission on the Pacific Coast. The specific object of each inquiry, the details of the work, and results accomplished are given in the following pages. The work was under the immediate direction of Professor Evermanu, assisted by Dr. S. E. Meek, associate professor of biology and geology in Arkansas State University; Mr. Ulysses O. Cox, professor of biology in the State Normal School at Mankato, Minn.; Mr. A. B. Alexander, fishery expert of the Fish Commission steaner Albatross; Mr. W. F. Hubbard, superintendent of the United States fish-hatchery at Clackamas, Oregon, and Mr. Alfred G. Maddren.

Investigations were carried on in ten different regions, as follows: (1) At the Redfish lakes in Idaho, by Messrs. Evermann, Meek, and Maddren; (2) at Lake Pend d'Oreille, Idaho, by Messrs. Alexander and Cox; (3) at Wallowa Lake, Oregon, by Messrs. Meek and Maddren; (4) on tributaries of the Lower Columbia, by Messrs. Evermann, Meek, and Hubbard, and by Messrs. Alexander and Cox; (5) on streams tributary'to Puget Sound, by Messrs. Alexander and Cox; (6) at Lakes Washington, Sammamish, and Union, by Mr. Alexander; (7) on the Siuslaw River, Oregon, by Dr. Meek; (8) on Whoahink, Tsiltcoos, and Tahkenitch lakes, Oregon, by Dr. Meek; (9) at Upper Klamath Lake, by Messrs. Meek and Alexander; and (10) at Crater Lake, Oregon, by Messrs. Evermann and Cox.

During the progress of this work the representatives of the Commission were the recipients of material assistance and many acts of courtesy from various citizens, to all of whom we are glad to acknowledge our indebtedness and to express our thanks. Especial mention should be made of Mr. G. H. Stevenson, Vancouver, Wash.; Seufert Brothers and Mr. I. H. Taffe, salmon-eanners at Celilo, Oregon; Mr. Frank Warren, salmon-canner at Portland; Captain Steers, of the steamer Lillian, Florence, Oregon; Mr. William Kyle and Messrs. Elmore \& Sanborn, salmon-canners at Florence; Mr. Leonard Christianson, of Acme, Oregon, and Mr. Scott Morris, of Ada, Oregon.

\section{THE REDFISH LAKES, IDAHO.}

It was found in 1894 that these lakes and their connecting streams afforded unusually good facilities for the study of the spawning habits of the chinook salmon and both forms of the so.called redfish. The matter was taken up in the following year and a continuous series of observations was carried on at those lakes from July 17 to September 24. A detailed account of those observations, together with full deseriptions of the physical features of the region, may be found in the published report, in the Bulletin of the United States Fish Commission for 1896, pp. 149-202. 
The investigations of 1895 resulted in the following conclusions eoncerning a number of important questions regarding these fishes, viz:

1. The chinook salmon resorting to the headwaters of Salmon River for spawning purposes reach the spawning. grounds in perfect condition, so far as shown by external appearances, no mutilations nor injuries of any kind having been seen. The many sores and mutilations seen upon them later in the season result from injuries incident to spawning, are received on the spawning-beds, and are not due to injuries received en route from the sea.

2. After spawning, the chinook salmon coming to these waters die in the vicinity of the spawning-beds.

3. The young chinook salmon remain about one year in the streams where they were hatched before beginning their journey to the sea.

4. The large redfish are identical with the blueback salmon, or sockeye (Oncorlynnchus nerka), and come up from the sea, as do the chinook salmon. They reach the spawning-beds in perfect condition, are mutilated there during the spawning seasou, and then die, never returning to the sea.

5. The small redfish spawn at the same time and on the same beds with the large redtish. They arrive upon the sparning-beds in apparently perfect condition, but soon become mutilated, just as do the large form and the chinook salmon, and then die without returning even to the lake.

6. Eggs of the small redfish laid in September in the inlet to Alturas Lake began hatehing on the 21st of March following.

7. The young redfish remain in Alturas Lake at least one year from the time when they were spawned.

The investigations of 1895 left unanswered, however, some of the most important and interesting questions concerning the redfish. It was not possible to determine when the large redfish arrives at the Idaho lakes, nor whether the small form is really anadromons. Both forms were already in Alturas Lake before the nets were set in the ontlet, on July 20. The importance of settling these questions, if nossible, and the desirability of repeating and verifying the observations of 1895 , justified the continuance of the work another season. Alturas Lake was, therefore, again visited in the summer of 1896. Camp was established July 11 on the outlet of Alturas Lake, at the ford about $1 \frac{1}{2}$ miles below Perkins Lake. On account of unusually high water it was impossible to set the gill nets satisfactorily until July 17 . On July 22 the camp was moved to the head of Alturas Lake and a gill net was placed across the inlet at its mouth. The net at the ford was taken up August 6 and reset in the outlet between Perkins and Alturas lakes, thus making it more easily reached from the camp. It remained in this place until September 25 , when it was taken up and not reset again. Redfish began to come into the inlet August 3. After that date the net was kept in place only at irregular intervals until August 14, when it was taken up.

High water.-The spring of 1896 was an unusually late one in Idaho. The snows of the preceding winter were mnch deeper than usual and were slow in disappearing in the spring. Rains were also uncommonly frequent, even late in the spring and during the first half of summer, the last of importance occurring August 6. A very hard rain fell on the night of Angust 3, resulting in a perceptible rise in the streams. On July 11 the streams were much higher than at the same time the year before. Salmon River and Alturas Creek were overflowing their banks in many places; much of the 
valley above Alturas Lake was from a few inches to 3 feet under water. Not until about July 22 was it possible to reach the head of the lake with a wagon, and the outlet could not safely be forded earlier than that date. After July 14, however, the water ran down very rapidly, and during August and September Alturas Creek was only slightly higher than in 1895 .

Temperatures.-Temperature observations were made as regularly as circumstances permitted. The records for July 11 to July 21, inclusive, are those made at the camp on the outlet of Alturas Lake. The thermometer for air temperatures was kept hanging in the shade on a tree at the camp; the water temperatures were taken in the creek at the camp in water about a foot deep.

Temperatures recorded at the outlet of Alturas Lake, Idaho, July 11 to 21, 1896.

\begin{tabular}{|c|c|c|c|c|c|c|c|}
\hline Date. & Hour. & Air. & Water. & Date. & Hour. & Air. & Water. \\
\hline July $\frac{11}{12}$ & 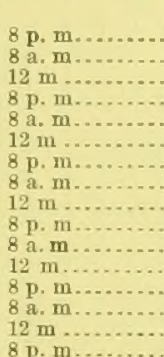 & $\begin{array}{l}\circ \text { F. } \\
62 \\
59 \\
71 \\
52 \\
52 \\
60 \\
55 \\
58 \\
70 \\
62 \\
63 \\
71 \\
61 \\
60 \\
74 \\
64\end{array}$ & $\begin{array}{l}\mathbf{F} \\
58 \\
56 \\
58 \\
55 \\
53 \\
55 \\
53 \\
53 \\
58 \\
54 \\
54 \\
57 \\
56 \\
60 \\
59 \\
56\end{array}$ & $\begin{array}{r}\text { July } 17 \\
18 \\
19 \\
20 \\
21\end{array}$ & 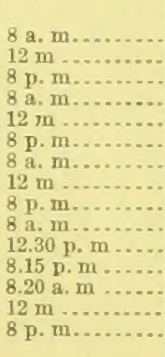 & $\begin{array}{l}\mathbf{F} \\
55 \\
73 \\
64 \\
55 \\
74 \\
64 \\
52 \\
72 \\
59 \\
56 \\
73 \\
60 \\
50 \\
76 \\
63\end{array}$ & $\begin{array}{l}\circ \mathbf{F} . \\
55 \\
60 \\
59 \\
58 \\
63 \\
60 \\
58 \\
62 \\
61 \\
58 \\
63 \\
61 \\
58 \\
63 \\
61\end{array}$ \\
\hline
\end{tabular}

The temperatures recorded in the following table are those taken at the camp at the head of Alturas Lake. The "inlet" temperatures were taken a few feet above the lake where the water was about 2 feet deep; those for the lake were taken just in front of our eamp at a depth of about 3 feet, and those of the air were in the shade:

Temperatures recorded at the head of Alturas Lake, Idaho, July 22 to August 5, 1896.

\begin{tabular}{|c|c|c|c|c|c|c|c|c|c|c|c|}
\hline \multirow{2}{*}{\multicolumn{2}{|c|}{ Date. }} & \multirow{2}{*}{ Hour. } & \multirow{2}{*}{ Air. } & \multicolumn{2}{|c|}{ Water. } & \multirow{2}{*}{\multicolumn{2}{|c|}{ Date. }} & \multirow{2}{*}{ Hour. } & \multirow{2}{*}{ Air. } & \multicolumn{2}{|c|}{ Water. } \\
\hline & & & & Inlet. & Lake, & & & & & Inlet. & Lake. \\
\hline July & 22 & 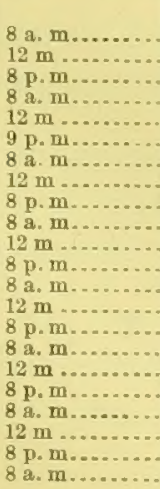 & $\begin{array}{l}\mathbf{F} . \\
62 \\
72 \\
60 \\
55 \\
64 \\
48 \\
46 \\
64 \\
56 \\
52 \\
69 \\
53 \\
46 \\
63 \\
53 \\
50 \\
64 \\
60 \\
48 \\
57 \\
49 \\
52\end{array}$ & $\begin{array}{l}\circ \mathrm{F} . \\
\cdots \ldots 1.5 \\
43 \\
47 \\
49 \\
41 \\
47 \\
51 \\
42 \\
48 \\
51 \\
42 \\
47 \\
51 \\
43 \\
47 \\
50 \\
55 \\
51 \\
49 \\
43\end{array}$ & $\begin{array}{l}{ }^{\circ} \mathbf{F} . \\
55 \\
57 \\
50 \\
53.5 \\
54.5 \\
51 \\
53 \\
55 \\
51 \\
54 \\
50 \\
51 \\
50 \\
59 \\
56 \\
54 \\
58 \\
59 \\
54 \\
56 \\
\mathbf{5 6} \\
56\end{array}$ & July & 31 & 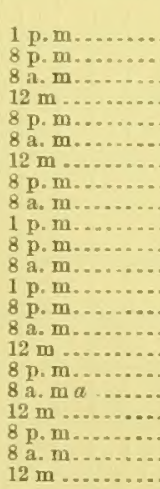 & $\begin{array}{l}0 \text { F. } \\
65 \\
54 \\
49 \\
68 \\
55 \\
53 \\
74 \\
59 \\
59 \\
74 \\
59 \\
57 \\
66 \\
53 \\
49 \\
70 \\
42 \\
41.5 \\
57 \\
44 \\
42 \\
60\end{array}$ & $\begin{array}{l}\mathbf{F} . \\
48 \\
50 \\
43 \\
49 \\
52 \\
44 \\
50 \\
51 \\
44 \\
52 \\
53 \\
44 \\
51 \\
53.5 \\
44 \\
49 \\
52 \\
42.5 \\
50 \\
51 \\
42 \\
44\end{array}$ & $\begin{array}{l}\circ \mathbf{F} . \\
59 \\
56 \\
56 \\
60 \\
58 \\
56 \\
59 \\
55 \\
58 \\
54 \\
55 \\
57 \\
58 \\
53 \\
57 \\
57 \\
50 \\
55 \\
51.5 \\
55 \\
55 \\
56\end{array}$ \\
\hline
\end{tabular}

a During the night of August 3 there were heary thunder and rain, snow falling on the mountains.

F. C. B. $1897-2$ 
In the following diagram are shown the temperature curves obtained by taking serial temperatures in Alturas, Big Redfish and Wallowa lakes. Two series were taken in Alturas Lake and one in each of the others.

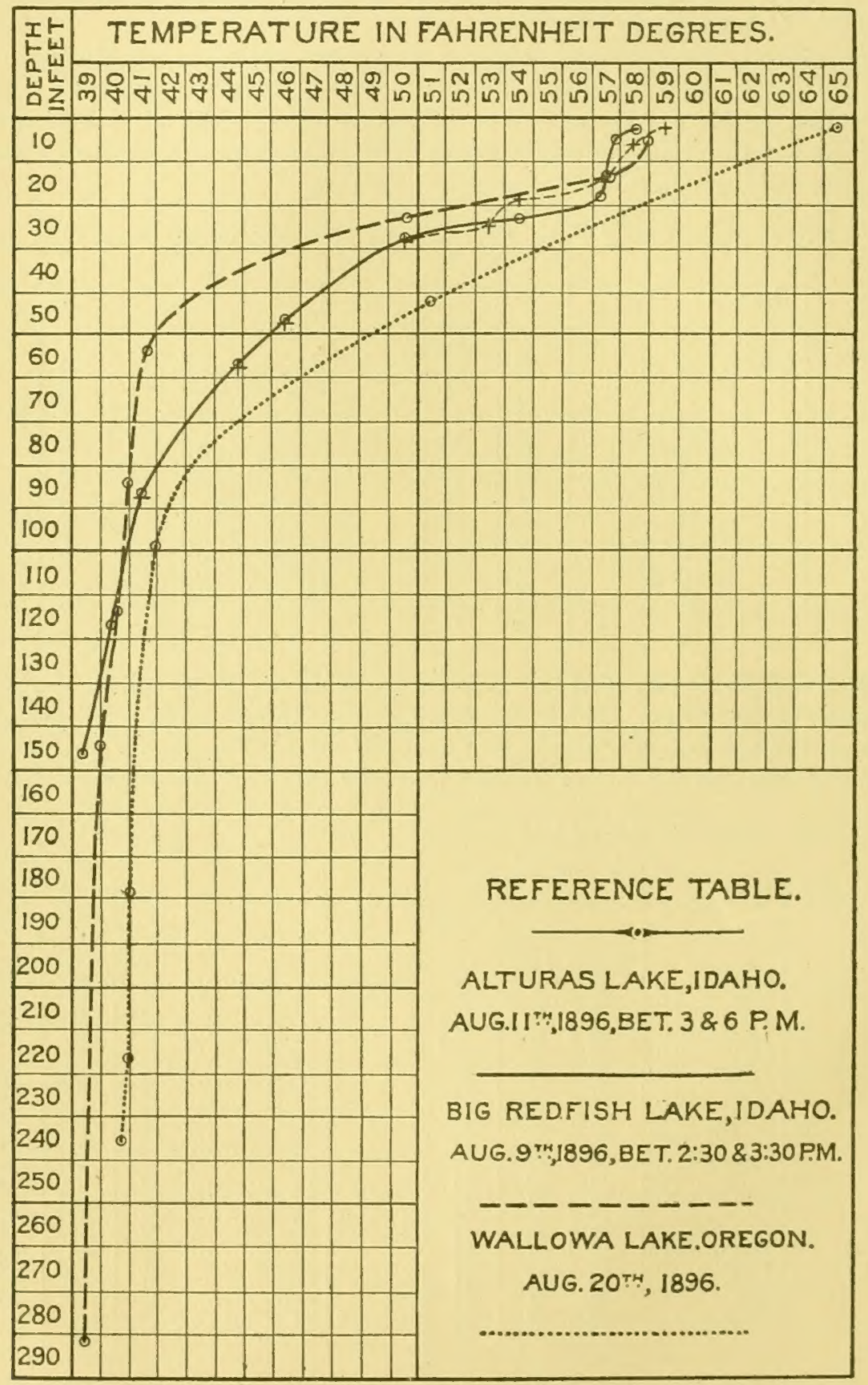


The following temperatures were taken August 11, in Alturas Lake just beyond the bar at the month of the inlet. All are bottom temperatures except the first three. The first, second, third, and fourth were all taken at the same place, the others a short distance away:

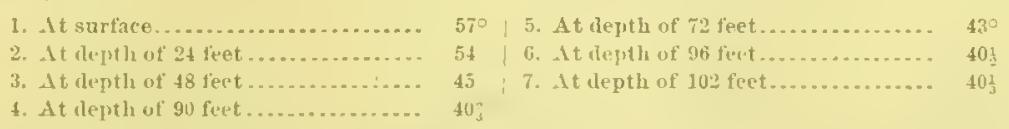

Two series of temperatures at different depths were taken in Alturas Lake $\lambda$ ugust 11 , between $3 \mathrm{p} . \mathrm{m}$. and $6 \mathrm{p}$. $\mathrm{m}$. These are shown on the temperature diagram on preceding page. The series indicated by the crosses shows tho-bottom temperatures, obtained by starting near shore in 1 fatbom and going outward into increasing depths. The circles on the continuous line indicate a vertical series taken near the middle of the lake, where the depth was 150 feet. It will be noticed that, after reaching a depth of 30 feet, the two series coincide exactly and that the temperature at the bottom in the deepest part of this lake is but slightly, if at all, above that of fresh water at its greatest density, namely, 390 .

A similar series was taken at Big Redish Lake August 9, betreen 2.30 and 3.30 p. m., the results of which are platted on the sane diagram, an examination of which shows that this lake is, as a whole, considerably colder than Alturas Lake. Though the surface temperatures are nearly the same, the water in Big liedfish Lake is seen to grow colder much more rapidly as the depth increases. This is apparently due to the greater size and depth of Big Redfish Lake, the lower temperature of the inflowing water, and the greater protection atororded by the higher surrounding mountains. In both lakes, however, the temperature decreases rapilly until a depth of about 100 feet is reached, and beyond that depth the decrease is less than 20 in either case.

These temperatures were taken with a Negretti-Zambra deep-sea thermometer tripped by means of a messenger, and the results aro believed to be reliable. The bottom temperatures which we took at these lakes in 1895 were taken with a Wilder protected thermonieter, and we are now convinced that the results obtained are wholly unreliable whenever the depth exceeded a few feet. The thermometer can not be drawn up quickly enough to prevent the mercury from being warmed by the warmer water above. The few bottom temperatures given in the report of the work done on these Idaho lakes in 1895 are therefore worthless.

\section{SUMMAIY OF (IBSERVATIONS REGATDING THF REDFISH.}

Camp was established on the outlet of Alturas Lake July 11, and obserrations began on that date. The daily inspection of the nets and the periodical examination of Alturas Creek and Salmon River were carried on essentially as during the season of 1895. Althongh gill nets could not be well placed until July 17, the opportunities for examining the stream make it certain that if any redfish had ascended to the lake between July 11 and 17 they. would have been seev.

Beginning with July 17, gill nets were kept constantly in the outlet of Alturas Lake, set in such manner as wholly to obstruct the stream to the ascent of fish. These nets were kept in place until September 25 , but not a single redfish, either of the large or small form, was canght in them. No redfish were seen in the outlet or elsewhere below Alturas Lake during the season. Small redfish appeared in the inlet in considerable numbers in August and September, but no Iarge redish were seen this year at any of the Redtish Lakes. 
The first redfish seen was caught in Alturas Lake near the inlet July 16, while fishing for Dolly Varden trout in abont 30 feet of water. It was a male, 11 in inches long, and was taken on a hook baited with salmon spawn. Its stomach was well filled with food, chietly small crustaceans. Its color was a rich metallic blue on the back, becoming silvery on the lower sides and under parts. The reproluctive organs were not greatly developed.

The next redfish were canght in the inlet gill net on the night of the $2 d$ of Angust, 3 males in prime condition. On the next night 3 more males were taken, in excellent condition and nearly or quite ripe. On the next night 8 males and 3 - females were canght, all the males ripe and the females nearly so. No others were seen until August 6 , when about 40 were observed in a deep hole about a mile above the lake.

As the redfish were now running up in considerable numbers, the nets were takeu up and not put down again except for one night, Angust 13, when 53 males and 32 females were caught. None of these showed any sores or mutilatious of any kind.

By the middle of August the fish had arrived in large numbers, the maximum being reached during the last week in that month. The fish in the inlet were connted at intervals and a careful record made of their numbers. The record reads as follows: 1,044 fish on August 18; 1,345 on August 21; 1,038 on August 25; 1,558 on August $28 ; 1,354$ on September $1 ; 1,515$ on September $4 ; 1,286$ on September $9 ; 1,067$ on September 12; 95: on September 14; 70:3 on September 18; 214 on September 25 ; 106 on September 28 ; October 2 , none.

The fish seen on the first few days were all in perfect condition, but soon after they began spawning mutilations appeared, and some died as early as August 23. After that date they died rapidly, but the numbers were reinforced from time to time by new sehools which continued to come up from the lake until probably the first week in September. The large decrease shown August 25, compared with the number observed four days earlier, was apparently caused by a great many tish being caught ont by campers. Begiming early.in September the number of dead fish increased and the number of live ones gradually decreased until October 2 , when all had died. The dead fish were usually found in the deeper pools or quiet portions of the inlet. On September 14 one dead redfish was found lodged against the net in the ontlet a few rods below Alturas Lake, and on September 25 four were found washed up on the shore of the lake a few rods west of the inlet. These had all doubtless been carried down by the current.

Run later than in 1895. - In 1895 the first redfish appeared in Alturas Inlet July 25, the miximum was reached about september 6 , and all had died hy september 2.5. In 1896 the run began nine days later, the maximum was attained abont nine days earlier, and the last live fish were seen about nine days later than in 1895. Though the season began a little later, it covered almost exactly the same length of time.

Mutilations.-Previous observations concerning the cause of the mutilations were verified. As the fish came into the inlet they were all in perfect condition, and con. timued and careful observation of their movements during the spatrning season showed conclusively that the injuries are caused by contict with the gravel and by tighting on the spawning-beds.

Dying of the redfish.-The conclusion reached last year, that every redfish dies after spawning once, was based upon absolute proof, so far as this region is eoncemed, and no other conclusion was possible from the observations made this year. The 
number of redfish entering Alturas Inlet in 1895 was about 2,000 in round numbers, and not one ever returned alive to the lake below. The run this year was somewhat larger. The greatest number counted at any one time was 1,558, but many had died or been caught by campers prior to that time, and many new schools came in subsequently. 'It is a conservative estimate to say that between 2,500 and 3,000 fish entered Alturas Inlet in 1896. While the observations for the purpose of determining whether any returned to the lake were not as carefully made as in 1895 , there is no evidence that a single fish ever returned to the lake alive.

While the mutilations are usually quite severe, in many cases they are not particularly so, and unmutilated fish were sometimes found dead or dying. This fact scems to be of great importance because of the light which it throws upon the probable canse of the death of spawning salmon. Some naturalists have maintained that the dying is attributable to the injuries; others that exhaustion resulting from the long journey from the sea or long abstinence from the use of food is the canse; but as a matter of fact, many observers have seen salmon dying in large numbers at the end of the spawning season in waters only a fer miles from the sea, and even in salt water, and the cause could, therefore, not have. been exhaustion resulting from long journeys without food, or mutilations received on such journeys. That the dying results from long abstinence from food is completely disproved by observations at Alturas Lake, where redfish have been observed to come up out of the lake with food in their stomachs, and have died a few days after spawning. The true cause is evidently deeper seated in its uature and more general in its application than has been supposed.

No large redfish seen in 1896.-In 1894, 14 large redfish were seen in Alturas Inlet and 1 in the inlet to Pettit Lake, and as these waters were visited only once this does not, of course, indicate the total number that may have spawned there in that year. In 1895 only about 8 large redfish were seen, 3 in the inlet to Pettit Lake, 3 in Alturas Inlet, and 2 in Alturas Lake. During the season of 1896 no large redfish appeared in Alturas Inlet, nor were any seen at Pettit Lake, which, however, was not visited sufficiently often to fully determine the matter. None was observed at Big Redfish Lake during a trip there August $S$ to 10, and parties who risited the lake during August and September report seeing no redfish.

Are the small redfish analromous? - This question can not yet be positively answered. If they are, they had reached Alturas Lake prior to July 11, just as they must have reached it before July 20, in 1895. But this may very well be so, for the bigredfish, which is undoubtedly anadromous, hat also reached this bake earlier in 1895 than July 20. Observations at Alturas aud Wallowa lakes point strongly to the probability of the small redtish being permanently resident in those lakes. The first of these was the catching of a small redfish in Alturas Lake July 16. This fish took the baited hook, and its stomach was found to contain some food, chiefly insect larve and small crustaceans. One caught in the gill net Angust 6 had a trace of food in its stomach. Twelve small redfish were caught with grabhooks in Wallowa Lake by Mr. J. J. Stanley, about the first of September, and the stomachs of 9 of them were found to contain food consisting almost wholly of entomostracans and other small crustaceans. In one case the stomach contained a small quantity of some alga and in five or six cases the stomach was quite full of food. 
The twelve specimens taken by Mr. Stanley were males which probably would have spawned that season. They are considerably smaller than any heretofore taken and vary from $6 \frac{3}{4}$ to 93 inches in total length; one found dead on the shore of Wallowa Lake Angust 24 is only $\tilde{5}_{+}^{1}$ inches long.

In the light of all these facts it is hard to believe that the small redfish come up from the sea. On the other hand, when we consider that the large and small forms present no structural differences of value, that they spawn at the same time and on the same beds, that the small form has never been seen, so far as known, in any of these lakes excejt at spawning time, and that they, like other members of the genus, dio after once spamning, it is equally dificult to believe that they are permanently resident in fiesh water.

Chinook salmon in the upper Salmon River.-The number of chinook salmon coming to these sparning-beds in 1595 was uot far from 1,000 . The first appeared Inly 24, aud the maximum number was renched about August 24. All arrived in perfect condition, and all died soon after sparuing, none returning to the sea.

Not much time was given to the chinook salmon in 1896 , only ocensional visits being made to Salmon River. From such observations as were made and from information obtained from various parties who came up the river from Stanley Basin and other points below, it appears that the run was very small and much later than in the preceding year. Four were seen in Alturas Creek, at the mouth of Pettit ontlet, Angust 24, and seven days later 7 more were seen in the Salmon River a mile below the mouth of Alturas Creek. On September 3, 8 were seen from this point down to lioaring Creek. The same fish, or possibly others, were seen at varions times until September 11, after which no more were seen. MIr. Springer, who was fishing and lunting for the Custer market, says that in Bear Valley and Sulphur creeks, where salmon have until this year been plentiful, not one was seen. He saw only 1 salmon in Salmon River below Roaring Creek.

\section{LAKE PEND D'OREILLE, IDAHO.}

In February, 1889, the United States Fish Commission placed in Lake Pend d'Oreille 1,300,000 fry of the common whitefish (Coregonus clupeiformis). Uutil now no investigation had ever been made to determine whether any of these fish survived. Fugitive reports have come to the Commission from time to time of the capture of examples of this species, but specimens submitter for identitication proved to be the common native species (Coregonus willinmsoni). If the plauted species succeded in establishing itself, the individuals would by this time have attained a size sufficient to enable them to be taken in gill nets.

Mr. A. I. Alexauder and Prof. U. O. Cox rere instructed to go to Lake P'end d'Oreille and endeavor to determine the result of the whitefish plant made in this lake in 1889, and to make investigations regarding the snitability of the lake, in its physical aud biologic features, to the common whitetish. The investigations rere beguu June 25 and it was hoped they might continue throngh the seasou, but, owing to urgent work on Puget Sound, which Messrs. Alexauder and Cox were directed to perform, the Pend d'Oreille investigations were discontinued July 16. Excessively high water prevailed during the time spent upon the lake and the conditions were not favorable for investigations of this kind. Gill nets were set in difierent places in the north end of the lahe, but no tests were made in the southern portion. While no 
whitefish were found, the result can not be regarded as conclusive. The investigations should be resumed and continued until the whole lake can be carefully examined.

The report upon the physical examination of the lake and upon the fish-food collected will be reserved until a more thorough study of this important boily of water can be made.

WALLOWA LAKE, OREGON.

It has been known for several years that both the large and small reltish have spawning-beds in the inlets of this lake, and that chinook salmon spawn in Wallowa River and other streams in that region. A short visit was made to Wallowa Lake by Messrs. Meek and Maddren on August 19, and they remained there and on Wallowa River uutil August 26.

Wallowa Lake is in the northeastern portion of Oregon and in the southern part of Wallowa County. It lies in the southern end of a considerable valley, which is bounded on the east, south, and west by the L'owder River Mountains. This lake is of glacial origin, and is borlered on the east and west siles by immense lateral moraines, which rise about 1,200 feet above the surface of the lake at the upper end, but become less high as the lower end of the lake is apmoached. Across the broad canyon at the foot of the lake is a terminal moraine a few feet high, through which the ontlet has cut its way. At the foot of each of the lateral moraines, about 20 feet above the surface of the water, is a bench from "20 to over 100 feet in width. 'This bench was evidently formed when the surfice of the lake was at that height. The outlet has ent a sort of canyon through the terminal moraine and lowered the lake to its present level. The sides of the moraines above and below these benches are very steep, aud except along the upper one-third of the lake there is very little timber on them. There is a dense growth of willows and alder along the south shore of the lake, extending backward into the valley about one-fourth of a mile. 'The rest of the valley near the head of the lake is quite heavily timbered.

The mountains near the head of the lake are very rugged, and are said to be over 5,000 feet above the surface of the lake.

Wallowa Lake is about $4 \frac{1}{2}$ miles long from north to south, with a maximum width of about 1 mile. The greatest depth found was 250 feet. Its shores are quite regular, there being $n$ marked indentations anywhere. The beach at the upper end of the lake is sandy; that on the other three shores is for the most part covered by bowlders. The iulet of this lake has its origin in some lakes about 3 miles farther up the narrow valley. The largest of these is said to bo abont half a mile in diameter. About $2 \frac{1}{2}$ miles above Wallowa Lake are Wallowa Falls. Just before reaching this point the inlet llows through a canyon about !o feet in depth, the height of the falls being abont 50 feet. The water fills into a basin about 50 feet in diameter, the outlet of which is 15 to 20 feet wide. A great many bull trout are canght with hook and line in this basin each year. Betreen the falls and the lake the inlet flows most of the distance, with a swift current, over a bed of bowlders. Within about lialf a mile of the lake the inlet breaks up into two or more chanuels, and finally discharges its waters into the like by two mouths, which are only a fer rods apart. The mouth of the inlet has been changed within the past few years. The stream is very swift and contains very few gravel beds, and these are along its lower mile. Another small 
inlet empties into the lake near its southeast corner; this inlet is only a small brook in summer. The lakes and the inlet above the falls are said to contain no fish life.

Wallowa liver, as it leaves the lake, is a very rapid stream and flows over a bed of bowlders. The first half mile of its course is through a canyon about 30 feet deep. From Joseph to Lostine the river is said to be very rapid.

The West Fork of Wallowa River rises in the mountains west of Wallowa Lake, and, after flowing in a general northerly direction until within abont a mile of the main fork at Lostine, it bends to the westward and joins the main fork a short distance below that town. About 12 or 15 miles below where these two forks come together Wallowa River is joined by Minam River, which forms a part of the western boundary of Wallowa County. The river here flows nearly due north, and soon unites with the Grande Ronde River, a tributary of Snake River.

About 4 miles from Lostine up the West Fork of Wallowa River, the river was narrower and Howed with cousiderable relocity among the luge bowlders scattered over its bed. About 3 miles above Lostine there is a somewhat level stretch in the river of about half a mile, which includes some gravel bars. From Lostine to the mouth of Minam River the Wallown is a rapid stream, Howing most of the distance over a bed of bowlders. Gravel or sand bars are not common. The water is very clear, and at the time of our visit was not over 3 feet deep in this portion of the stream. Minam River is smaller and is said to be very similar to the Wallowa. The Grande Ronde River was seen at Lagrande and Elgin and at various places between those towns. It appears to be a rather sluggish stream, the water being warm and muddy.

Soundings and Temperatures.-The following soundings and temperatures were taken on Wallowa Lake about half a mile north of the south end of the lake. We began on the west side and counted the strokes of the oars as we crossed, taking soundings and temperature at intervals, as shown below. The first sounding was made 20 oar strokes from the west shore.

Soundings and temperatures taken in Wallowa Lake, Angust $20,1836$.

\begin{tabular}{|c|c|c|c|c|c|}
\hline $\begin{array}{l}\text { Strolies } \\
\text { taken } \\
\text { between } \\
\text { aound. } \\
\text { ings. }\end{array}$ & Depth. & $\begin{array}{l}\text { Temper- } \\
\text { ature at } \\
\text { bottom. }\end{array}$ & $\begin{array}{c}\text { Strokes } \\
\text { taken } \\
\text { between } \\
\text { soumt. } \\
\text { ings. }\end{array}$ & Depth. & $\begin{array}{l}\text { Temper- } \\
\text { ature at } \\
\text { bottom. }\end{array}$ \\
\hline $\begin{array}{r}170 \\
20 \\
100 \\
100 \\
100 \\
100\end{array}$ & $\begin{array}{c}\text { Feet. } \\
42 \\
216 \\
236 \\
234 \\
228\end{array}$ & $\begin{array}{l}{ }^{5} \text {. } \\
51 \\
40 \frac{1}{2} \\
40 \frac{1}{5} \\
40 \frac{1}{6} \\
40 \frac{1}{2}\end{array}$ & $\begin{array}{l}\text { No. } \\
50 \\
30 \\
30 \\
35 \mathrm{str}\end{array}$ & $\begin{array}{c}\text { Feet. } \\
219 \\
180 \\
99 \\
\text { kes to ens }\end{array}$ & $\begin{array}{r}\text { F. } \\
40 \frac{3}{3} \\
40 \frac{2}{3} \\
41 \frac{1}{2} \\
t \text { shore. }\end{array}$ \\
\hline
\end{tabular}

The greatest depth, 250 feet, was about a mile from the south end of the lake and about a third the distame across from the west shore: the bottom temperature liere was 4010. About a quarter of a mile south of this point and near the middle of the jake from eatst to west a depth of 246 feet was found, and the sime bottom temperature. A series of temperatures taken August 20 is platted on page 18. The surface of the iake near the iulet at $3 \mathrm{p}$. m., A ugust 24, was $62 \circ$ when the air was $70^{\circ}$. The temperature of the east inlet at the same time was $52^{\circ}$ and the other was $48^{\circ}$. The water in a small spring ereek was $44^{\circ}$. 
Redfish at Wallowa Lake.-No large redfish were seen at the time of our visit to this lake, Angust 19-26. From interviers with persous familiar with the region it appears that the large redfish usually reach the lake during the last half of July. They come up the river with the first run of chinook salmon, the run into the lake lasting about three rreeks. Soon after entering the lake they are seen in large schools at its upper end. They begin to spawn in September. They are not red when they enter the lake, but become so a short time before spawning. They spawn in the inlets of the lake and on the shores of its upper end. They were formerly caught for the market during the month of August. According to Mr.J.J. Stanley, of Joseph, the run of large redfish in Wallowa Lake in each year since 1882 was as follows:

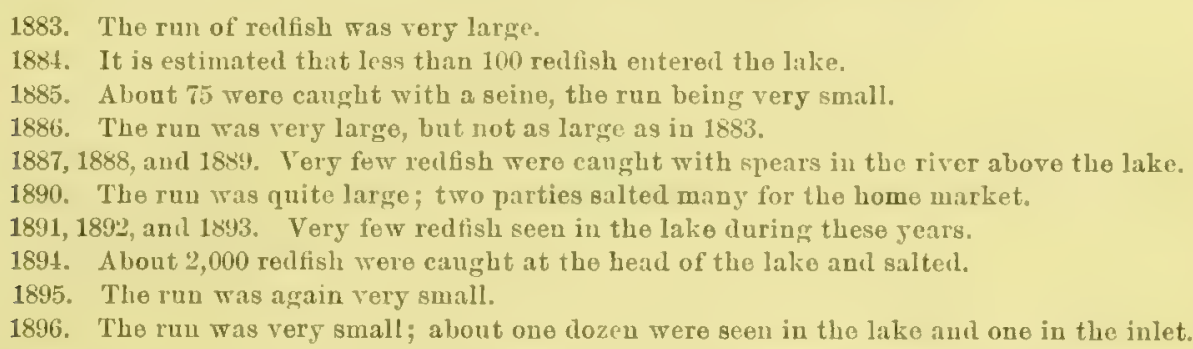

In the spring many small fish, from about 6 to 8 inches in leugth, are stranded in irrigating ditches, many others are killed by entering mill-races. By the inhabitants of Joseph these are thought to be the young of the big redfish on their way to the sea. The large redfish are not known from any streams in this region except in the lake and its outlet and inlets. It is said never to run up the West Fork of the Wallowa River. Only one small redfish was observed while at TTallowa Lake, a small example $5 \frac{1}{4}$ inches loug, which was found dead on the lake shore August 24.

According to Mr. Stanley, the small redfish are seldom or never seen there except in September, and then only in schools at the head of the lake or in the inlets where they spawn, at the same time and on the same beds with the large redfish. He says the small ones are called "yanks," and that not more than 1 in 15 is a female; 12 which he caught for us were all males. According to Mr. Stanley, the fish which he calls "grayling" is usually seen only in June, when it is easily canght by trolling in the lake. The small redfish found dead on the beach of Wallowa Lake, Angust 24, was called a grayling by Mr. Stanley, from which it seems probable, that the so-called "grayling" are the more silvery small redfish.

Chinook salmon.-This salmon is known to enter both the West and Main Forks of Wallowa River, the majority rumuing inte the West Fork. Those which keep in the Main Fork enter Prairie Creek, where they have their spawning-beds. They have been seen in the outlet close to the lake itself. The early run is in July. The largest run is in September when they are known locally as "dog salmon."

West Fork was examined for a distance of 4 miles, that portion of the river most frequented by chinooks, but no salmon were seen. Four had been caught, however, ou the spawning-beds 3 miles above Lostiue a few days before, and one was killed by an Indian below Lostine about the same time.

Steelhead trout. - The steelhead reaches Lostine on the Wallowa River in March and April. They spawn mostly in the West Fork of Wallowa River, very fer being seen in the Main Fork. 
LOWER COLUMBIA RIVER.

It being the desire of the Commissioner to establish a station for the hatching of salmon in the Lower Columbia River basin, we rere directed to visit and examine varions streams, particularly in the vicinity of The Dalles and Cascades, and select a site suitable for such purposes.

The conditions requisite for such fish-cultural operations as were contemplated are essentially as follows: (1) An abundant supply of salmon easily obtainable when ripe, or nearly so; (2) water of proper quality as to purity and temperature and in sufficient quautity; (3) suitable land upon which to locate the hatchery building, and so situated as to permit the water to be brought to the hatehing-troughs by means of gravity; (4) proximity of building materials and good railroad facilities.

Upon taking up this inquiry it became at once evident that no definite informa. tion existed concerning the location of salmon-spawning beds anywhere in the Lower Columbia River basin and information regarding the sparning time was equally uncertain aud unreliable. It was therefore necessary to visit as many streams as possible and determine the facts by personal inspection and by interviews with people living on or near them.

The telegraphic instructions dated Angust 1 directed that a site be definitely selected, and as soon as possible, in order that the station might be operated during the season of 1896. In order to be able to examine as many streams as possible in the brief time at our disposal Messrs. Cox and Alexander rere ordered from Pnget Sound to examine the Lewis River aud other streams below Vancouver, while Messrs. Evermann and Hubbard made examinations at the Cascades, The Dalles, Hood Liver, Big White Salmon, and Celilo. These inquiries were made during the first ten dars of August. Later (August 2S to September 6) Messrs. Evermann and Meek examined the Des Chutes, John Days, Hood, Big White Salmon, and Little White Salmon rivers, and on September 7 and 8 Messrs. Evermann and Hubbard reexamined Little White Salmon River and examined Tanner and Eagle creeks near Bonneville. Mr. Hubbard also visited Hamilton and Rock creeks across the river from Cascades, and Mr. Alexander male an examination of Toutle River, Washington. Only the more important results of these various inquiries are given here, detailed reports having been made at the time to the Commissioner.

\section{LEWIS IRIVER.}

'This river forms the boundary between Clarke and Cowlitz connties, Wash., and Hows into the Columbia between Vancotier and Kalama. 'Two main branches, known as the North Fork and South Fork, unite only a fer miles above the month of the river. The North Fork has its headwaters on the exstern slopes of Mount St. Helens; the Sontl Fork rises in Skamania County, sontheast of Mount St. Helens. No salmon were seen in the North Fork at the time of MIr. Alexander's visit, during the first week in August. It is saill that the salmon of the spring run do not enter the river, but that large numbers of chinook salmon of the fall run enter it; also a good many silver salmon and steelheads. The chinooks are said never to run in until after the 10 th of Angust, when the close season begins. When tho close season ends (September 10) fishing with gill nets and seines is carried on to some extent in this river. Some logging is carried on in this stream during the spring, but it ceases long before the salmon arrive. 
Considerable spawning-beds are said to be located in the vicinity of Litna. The water is pure and coll, and if chinook salmon really come there in large numbers all other conditions are favorable for fish-cultural purposes.

The South Fork was exanined as far up as La Center. 'This stream is about the same size as the North Fork, but the water is not clear. 'The banks, in the lower portion at least, are composed of red clay or easily disintegrated rock, and the water is thus usually liept more or less muddy. Below La Center there seems to bu no bottom suitable for spawning-beds aud there are no tributary ereeks from which water suitable for hatchery purposes conld be obtained. Chinook salmon of the fall run are said to enter this fork, but the locality of their spawning-beds is not known. No salmon were seen by Professor Cox at the time of his visit.

\section{TOUTLE RIVEI.}

This stream is an eastern tributary of the Cowlitz, into which it flows a few miles north of Castle Rock. About 11 miles above its month is a fall 15 feet high. From this point down there are many riftes suitable for spawning-beds, and where racks could be put in without difficulty. One of the best places is at the month of Pat's Creek, abont 7 or 8 miles above the mouth of the river, where the stream is 35 to 75 feet wide and the bed is of coarse sand and gravel. Suitable water for hatchery purposes could be obtained from the creek.

It is elaimed that the fall rum of salmon enters this river in considerable numbers, including chinook, silver, dog, humpback, and steelhead. Salmon appeared to be scarce at the time the river was examined, as only three were seen by IIr. Alexander; but it was stated that they would be more abundant about the 1 st of September. They are said to collect in numbers at the foot of the falls already alluded to, and if this be true, that rould prove a good place for collecting the eggs. The falls do not seem to offer an impassable barrier, as salmon are reported from points still farther up the stream.

\section{CASCADH LOCKS.}

On the Washington side of the Columbia River, opposite Cascade Locks and at the head of what is known as the "Old Incline" at the Upper Cascades, is a place where it was thought fish-cultural operations might be carried on snccessfully. The fish wonld have to be caught in wheels, several of which are operated, in the vicinity, and held until ripe in a retaining channel or pond. This channel has sufficieut water flowing throngh it, can be easily racked at each end, and seems in every way fairly well suited for such a purpose. There is a good site for the buildings and sufficient water is obtainable by gravity from a small creek near by. It is clained that an abundance of salmon can be obtained by ruming the wheels in August and September and that they will be so mearly ripe that retention in the pond or channel will be necessary for only a short time.

An effort was made in August to transport fish caught in these wheels to the retaining pond, but it proved a failure. Whether due to lack of care and skill in making the transfer, or to inherent difticulties, is not certain, but we believe there is no good reaso! why salmon may not be safely transferred at this place. We question, horrever, whether they would live in the retaining pond until ripe, unless the poud be rather deep and kept dark. 
CELILO.

Mr. A. B. Alexander was directed by the Commissioner to visit Celilo, Oreg., for the purpose of watching the daily catch of fish taken there in wheels. He arrived there September 17 and remained till September 23 . His report is in substance as follows:

Only one wheel was in operation September 17. Two others close by were not ruming, owing to low water. It was expected to pack 4,000 cases, but by September 23 less than 1,000 cases had been packed. The fill run of salmon was very light in nearly all parts of the river. The accompanying table will show the daily catch for one wheel, with their condition, etc.

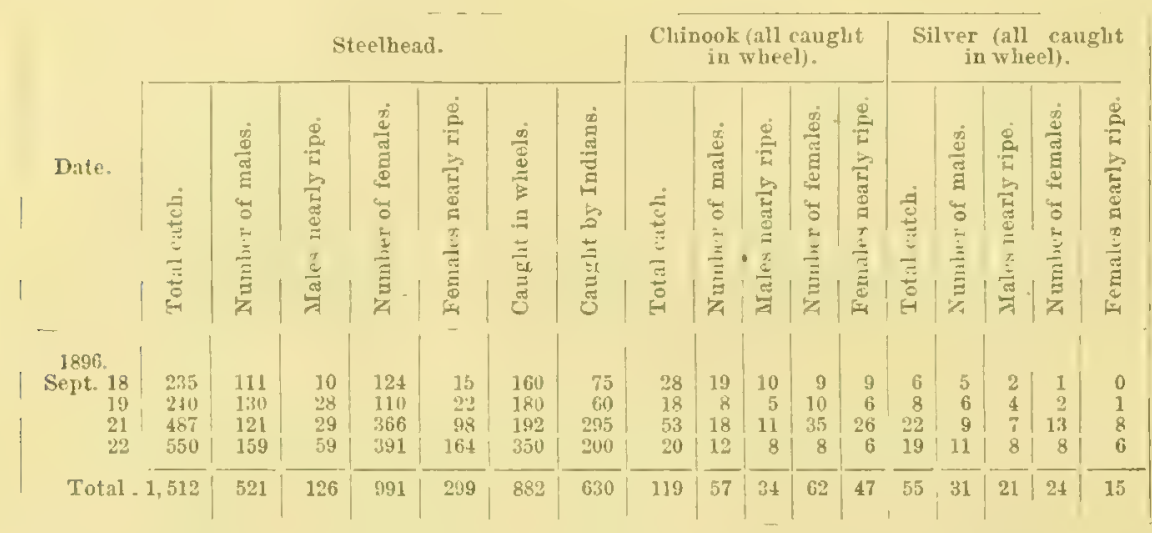

Among the 119 chinooks, 13 were small males, with their milt as fully developed as that of the large fish. The wheels sometimes take these fish in considerable numbers. The Indians prize them highly and seldom offer one for sale. Those examined were quite uniform in size, few weighing over $4 \frac{1}{2}$ pounds, the minimum being about 3 pounds. In length they vary from $12 \frac{1}{2}$ to 23 inches. Their color is very dark, the spots not being visible a distance of 10 feet. On closer inspection all the marks of a large chinook are visible. Fishermen usually do not class this tish with the chinook, but think it a different species.

The chinooks taken in the fall of 1896 at Celilo were said to be somewhat larger than those for several years past, the average weight heing 20 pounds; a verage length, 37 inches; greatest length, 43 inches. The average was about 1 pound larger than the usual fall run, and 1 pound less than the spring fish.

'T he steelhead varied in length from 25 to 42 inches, the average weight of those taken at Celilo being 18 pounds. A few weighed from 35 to 37 pounds. On first coming from the water the steelhead is very brighteolored, the large specimens having a bright stripe extendiug along the sides the whole length of the body, varyiug from a light pink to a deep brouze. The colors are very pronounced when the fish is first canght, but grow dim on being exposed to the air.

Silver salmon are from 18 to 30 inches loug; their average weight is 7 pounds.

Early in the fall Seufert Bros. operated three wheels, but two of them could not be run after the river had fallen. Mr. Tafle's wheel was adapted to low water. An island lying between Celilo and Tumwater is exposed when the river is low, the 
water on the south side of the river flowing over a rocky ridge forming falls some 12 or 15 feet high. Many salmon find their way to the foot of the falls aud endeavor to ascend them and when the water is about half low many succeed, but when the distance from the lower to the upper current of water is from 8 to 10 feet thousands of salmon at times may be seen jumpiug into the whirlpools at the foot of the falls. Just above the falls are two wheels, the larger on a rocky point projecting into the river. When the river is high, many of the salmon pass by this point over that part of the river where the falls are during low water. 'The wheel here catches fish only when the water is high; the other wheel, at the head of a channel, takes fish when the water is low.

The wheels in operation during the fall months are built in places where the water is deep and the current swilt. There being few natural places iu the vicinity where wheels cain be successfully operated, long deep channels have been cut through the voleanie rock and the water led into them. At or near the head of these artificial channels the wheels are built. The water rushes through the channels with considerable force, offering a strong inducement for salmon to exter. On arriving at the foot of the falls and finding it impossible to go farther salmon naturally enter the channel which leads to the wheel. If the water is very clear, the fish will congregate in large numbers in pools and eddies near the mouth of the channel and at the foot of the falls, remaining there for days without attempting to go up the ehannel. Sometimes several thousand fish will crowd themselves into the month of the narrow channel and remain there for hours at a time. Suddenly, as if by one impulse, they will dart up ehamel, and are soon canght up by the revolving wheel and landed on the platform in the fish-house.

Wheels are built in places near high-water mark where salmon are known to run in greatest numbers. The migratory habits of all species of salmon visiting the. Colnmbia River in the vicinity of The Dalles are said to vary from year to year. This often causes a considerable expenditure of money iu wheels frequently followed by negative results. For several years the main run of salmon may pass certain points in the river, when suddenly a new route will be selected. This change often transfers the best fishing-ground from one side of the river to the other, and wheels which have made large catches one season prove a failure the next. Only those with long experience in this locality are competent to select good sites for wheels. Several wheels on the river, built at a cost of from $\$ 3,000$ to $\$ 5,000$, have never taken a fish. This method of fishing requires consilerable capital.

On September 18 and 19 a large number of fish, mostly steelheads, were noticed to ascend the falls, but, as the river was falling rapidly, in a short time they were prevented from taking their natural course and were forced either to enter the channel or remain in the pools or eddies at the foot of the falls. At this time the wheel at Celilo began to take more fish than it previonsly had, the daily cateh increasing during the time Mr. Alexauder was there. The catch of chinook and silver salmon was small as compared with the number of steelheads. The last-mentioned species is always found in greater numbers at this season, the fall run of chinook being limited in number. Only a few silver salmon are caught here.

This season, owing to the unusual seareity of fish at Celilo, the cannery there did not put up any spring fish, the rum being very small. The great bulk of salmon was taken in wheels below the Cascades. Arriving at this point, they seemed inclined to go no farther up, and the camneries in that locality made large packs. Fish expected 
at The Dalles in the spring did not appear until about the close season. A large body of steelheads passed up the river during that time. Ordinarily the run of steelheads arrives at The Dalles early in September, but this year most of the run passed by during the close of the season.

On September 18 the wheel at Celilo took 160 steelheads, $2 S$ chinook, and 6 silver salmon, and 75 steelheads were taken by Iudians with spears and dip nets. Of the steetheads, 111 were males and 124 females; 10 males and 15 females were in an advanced stage of development, and would bave been ripe in a comparatively short time; the rest of the catch would not have been ripe until late in the seasou. Of the chinooks, 19 were males and 9 females; 10 males and all of the females would have been ripe by abont the first week in October.

During the five days spent at Celilo 1,512 steelheads, 119 chinook, and 55 silver salmon were examined. Of the steelheads, 991 were females and $5: 1$ males; 299 females and 126 males showed considerable signs of development, and would have been fully ripe by the first week in October.

As the river falls many places are left bare wheresalmon were caught earlier in the season. Sharp rocks are exposed, small peninsulas formed, and rocky islands appear where a few months before there was nothing to indicate their presence except an occasioual small whirlpool or riftle. At such places Indians fish with spear or dip net. Each fall several tribes from various parts of the State camp at Celilo and Tumwater, remaining there until the season is over. They fish for the canneries principally, but also lay in a supply of salmon for themselves. In pleasaut weather when salmon are plentiful they do a lucrative business. Sometimes one man catches 35 salmon iu a day. Their fishing is with a dip wet and detachable gaff hook and is carried on in swift water, the men standing on overhanging rocks or slielving places where a foothold can be had. This is dangerous work, and not a few lives hare been lost from time to time. When the wind is high, one of the strong gnsts that frequently sweep the river may suddenly strike a fisherman unprepared to receive it and blow him into the river. Each fisherman who stands in a dangerons place therefore has a rope fastened around his waist and secured to a rock.

In the whirlpool of water ouly an occasional fish can be seen and the fisherman stands and dips blindly. Sometimes a hundsed dips or more will be made without a fish being taken, at other times one will be canght at almost every dip. Where the water is less turbulent salmon are taken with spears, each spearsman having his particular standiug-place, from which he keeps a vigilant wateh, few salmon escaping that approach within throwing distance.

The Indian is assisted by the women and children of the tribe, who gather the fish when caught, throwing them into a pile on the rocks and rendering such other assistance as may be required. As soon as the day's fishing is over the Indian leaves the fish to be taken care of by the women, and they are taken from the island to the mainland, and carried in baskets over a steep, rocky path to the cannery, a distauce of about a third of a mile. When there is a good eatch mauy trips are required to be made to the cannery. A male Indian seldom does this kind of work; he is quite willing that it should be performed by the women, and raises no objection when young sirls are pressed into the service by their mothers. Sometimes, however, small boys lend assistance, but by the time they arrive at the age of 12 they have caught the spirit of their elders and refuse to do woman's work. 
When salmon are plentiful an Indian can earn from $\$ 5$ to $\$ 8$ a day. The price varies from year to year, according to the supply and demand for salmon by the canneries. This season 2 cents a pound was the standing price for chinooks and steelheads. Indians consider the chimoolis superior to all other salmon, and it is only when plentiful that they are sold to eanneries. No part of this fish is thrown away; the ripe eggs and even the tail, head, and fins are eaten.

The dwarf chinools, previously spolien of, not being used by cauneries, are greatly sought after by the women of the tribes, who sijuat on the floor of the room where the fish are dressed, patiently waiting for the small fish to be culled out. They sit for hours shivering in the cold, and consider themselves well paid if each receives one or two fish. During the fishing season the women and children congregate in the dressing-room, waiting for a share of the beads, tails, and fins as they fall from the butcher's knife.

The ripe eggs of chinook salmon are considered a great delicacy and are gathered in large quantities. They are first separated and then dried in the sun, after which they are prepared in various ways as food.

Steelheads swim near the surface and are more easily caught than tho chinooks, which swim leep. Clear water intuences the catch; if the water be clear the catch is less than when it is muddy.

From September 25 to the 13 th of October 2,667 steelleads, 1,402 chinooks, and 2,213 silver salmon trere examined at Celilo; 1,010 of the steelheads were males and 1,657 females; 683 of the chinooks were males and 719 females; of the silver salmon, 1,011 were males and 1,202 females; 350 male steelheads and 601 females were in an advancer stage of ripeness; also 574 male and 528 female chinooks, and 843 male and 1,048 female silver salmon.

The eggs and milt of the salmon caught during October were somewhat further advanced than that of those examined in September at Celilo. A large part of the eggs of the chinook on being taken from the fish would immediately separate; this was also true of many of the silver salmon and steelheads. A number of the latter showed no signs of development, but many were rell advancell and some about ready to spawn. It would seem that the sparning season of the steelhead extends over a greater period of time than that of other species. A careful examination carried on in other streams would no doubt throw more light on the snbject.

In the fall, after the close season, a seining "gang" of twelve to fitteen men goes into camp on a long pebbly bench, abont a mile below the fishing station at Tumwater. This season two seines were operated on the Oregon side of the river and one on the Washington side. At times fish will be found plentiful on one side of the river and few on the other, when suddenly, without apparent cause, they shift to the opposite side.

During the fishing season seining is carried on with little or no iuterruption, hauls being made in quick succession all through the day. The seines are set from a thatbottom boat, one end of the seine rope being held on shore by horses while the net is being thrown out. As soon as the net is set the seine rope on the lorrer end is picked up by other horses and the hauling-in commences. It would be impossible to land the net by hand, so swift is the current, and frequently the united strength of four horses is barely able to land it. At each haul the fish caught are loaded into wagons and taken to the fishing station, where they are reighed, washed, and put into cars. If they are to be canned they are thrown into the car in bulk; if shipped east, they are 
packed in boxes and iced. In the early part of the fall season the demand for fresh steelheads is large, and there is more profit in shiphing tish east than in canning them.

The only place noticed near Tumwater where salmon could be held for spawning purposes is near the seining-ground on the Washington side of the river. Here a channel has been cut, but owing to the small number of fish that entered it the wheel built near its head and also the channel have for sereral years been abandoned. On the lower end of the channel is a small iuclentation where an eddy is formed; a dam could be bnilt here and also one across the month of the upper end of the channel, with iron screens at either end. By covering the top of the channel, either the whole or a part of it, an inclosure would be formed which would hold a large number of salmon. It seems reasonable to suppose that salmon would live much longer in an inciosure of this kind than in boxes, as they would be crowded far less and have a better circulation of water. A swift current or comparatively still water could be had by putting in a gate at the upper eud of the chamel. The cost would be considerably more than keeping salmon alive in cars or boxes, but it is thought that the results would be more satisfactory.

\section{SEUFERT'S TUIWATER.}

On the Washington side of the river, opposite Seufert Brothers' cannery, is an excellent seining-ground, where salmon are said to be caught in large numbers. Within a few rods is a narrow channel of the river suitable in every way for a retaining pond. The hatehery building could be placed upon grout quite close to the retaining channel and where a supply of suitable water can be led by gravity. Seining is carried on principally for silver salmon ani steelhearls; many chinooks are also cauglit, but they are so near the spawning condition that they are not used for canning. The probabilities that fish conld be secured here aud retained for a short time until ripe are greater than at the Caseades, and the expense would be very slight.

JOHN DAY RITER.

This river was examined at its mouth September 2. It is there a stream of moderate size, quite shallow, and very muldy. The banks and bottom for some distance above the month are of mud or sand. Farther upstream the water is, of course, mueh clearer. Salmon could donbtless ascend the John Day River, but it is not certain that they do so in any numbers, and none was observed. Interviews with persons living on or familiar with the upper course of the stream failed to elicit any evidence that chinook salmon are now found there. It is said that a good many salmon formerly entered this river and spamned in the spring, but these are evidently steelheads and not chinooks. A few years ago a wheel was operated in the month of the John Day, but it has not been run for two or three years.

DES CHUTES RIVER.

The Des Chutes Iirer has its source on the eastern slopes of the Cascade Mountains and elserhere in Crook County, Oregon, flows nearly north and joins the Columbia about midway between the mouth of the John Day River and The Dalles. It has been generally regarded as the best salmon-spawning stream in the lower Columbia basin, and it was reported that large numbers of salmon can be seen at any time in the fall in this river at Sherar's Bridge, 30 miles from The Dalles or about 40 miles above the mouth of the river. This place was therefore visited from August 29 until September 1. 
Throughont the lower portion of its course this river luas cut a narrow, deep channel in the lava beds. The canyou's walls are so abrupt that it is impossible to reach the river in many places. At Sherar's Bridge the canyon widens out a little and the river here has a fall of 8 or 10 feet. Below the falls the river is compressed in to a very narrow gorge, through which the water rushes with much fury. At the bridge the water is said to be 86 feet deep, which is about equal to the river's wirlth at that point. Immediately above the falls the river widens out greatly and is very shallow for some distance.

Until within the last six or eight years "salmon" were seen here every spring in considerable numbers. Mr. J. H. Sherar, who has lived at these falls for many years, says "salmon trout" were present throughout the year, but were not abundant except in the spring, and that they spawned in the spring; they had no diticulty in ascending the falls, and his understanding has always been that many of them went far toward the headwaters to spawn. Formerly Mr. Sherar caught large numbers of these salmon trout, but he has seen lut very few for four or tive years.

Several persons who live on the upper course of the Des Chutes, report that formerly a good many "salmon tront" were seen there in the spring, which was their spawning time, but that few if auy have been noticed for several years. It would appear that the chinook salmon has never rum into the Des Chutes in large numbers and that few enter it now; that the fish which at one time was rather abundant is the salmon trout or steelhead, salmo gairdneri. The sparning-beds in this river are too remote from the railroad to be available for fish-cultural operations.

\section{ILOD RIVEL.}

This stream is fed chiefly by the snows and glaciers of Mount Hood and flows into the Columbia at Hood River Station. It does not appear to ever have been frequented by chinook salmon in large numbers. The people at Hood River Station do not think that many salmon enter this river, and persons living several miles mp the river say that salmon are seen there but rarely.

\section{HIG WHITE SALIION RIVER.}

This river was examined August 6, and again on September 4. It is a stream of considerable size, having its sources on the western and southern slopes of Mount Alams. It flows in a general southerly course and empties into the Columbia nearly opposite Hood River Station. It is, in its lower course at least, a rough, turbulent stream, full of rapids and large bowlders, and flowing between high. aud, in some places, precipitous, banks, so that it is dificult to reach the edge of the stream. At the mouth of the river the canyon widens out and there is a little level land along the stream. In August all of this was Hooded by back water from the Columbia, but in September it was dry. No salmon were seen on our first visit, but on September 4 quite a number were observed jumping in the Columbia about the mouth of the tributary stream. On that date Indians had established two camps at the mouth of the river for the purpose of taking salmon during the season. They go up the stream from a quarter of a mile to a mile and capture the salmon by means of gaff-hooks on the ends of long poles. Only four salmon rere taken during an afternoon. While the couditions are not favorable for operating a hatchery on this river, a good many eggs could probably be ohtained and carried to any station which may be established on the lower Columbia.

$$
\text { F. C. B. } 1897-3
$$




\section{LITTLE WHITE SALMON RIVER.}

This stream enters the Columbia about 6 or $S$ miles belor the month of Big White Salmon Rirer. It was examined September 5 and 7 , and the prospects for successful salmon-cultural operations appeared so good that a site at the mouth of the river was selected and preparations begun at once for equipping the station. Salmon were already in the stream in large numbers and spawning had begun. By the time the station was ready to begin operations the height of the spawning season had arrived, but more than "2,000,000 eggs were taken, and it is believed by Mr. William P. Sauer. hoff, superintendent of the station, that $10,000,000$ eggs could have been obtained if operations had begun earlier in the season. The success attending the operation of this station is highly gratifying. Up to the time of writing these lines (O) tober 30,1897 ) the total number of eggs taken at the Little. White Salmon Station this season is over $12,500,000$.

TANNER AND EAGLE CREEKS.

These are two small streams flowing into the Columbia at Bonnerille, Oregon. The smaller is Tanner Creek, whose month is only a few rods west of the railroad station. It was examined september 7 by Messrs. Evermann and IInbbard, who found about 300 chinook salmon in the stream within a mile of its month. Most of the fish were lying quietly in deep holes, but some were in shallow water aud evideutly spawning.

The month of Eagle Creek is about half a mile east of Jomeville. This stream is considerably larger than TanneroCreek. Its bed is exceedingly rough and rocky, and only with much difficulty can salmon ascend it. A large bunch of salmon were lying in the deep hole under the railroad bridge and a few others were seen a short distance firther up the creek. Though these creeks are small, from 1,000,000 to 2,000,000 eggs could probably be taken there aunually and carried to the Little White Salmon Station.

Across the river from Bonnerille, and only a short distance below Little White Salmon River, are keveral streams into which salmon are said to rum. Among these are Little Wind River, Wind River, Smith Creek, Rock Creek, Hamilton Creek, aud Hardy Creek. Some of these are unsuitable for salmon on account of large quantities of wood which are floated down, aud bars sometimes form across the months of others, especially Hamilton and Hardy creeks, so that salmon are not able to enter; but usually a good many salmon spawn in these creeks, and donbtless a great many eggs could be collected from them. Their proximity to the Little White Salmon will make it easy to carry the eggs to that station.

\section{PUGET SOUND.}

In connection with the work of the joint commission appointed to investigate the lisheries of the contiguous waters of the T'nited States and Canada, certain investigations were made hy Messrs. Alexander and Cox concerning tho morements of the sockeye or blueback salmon in Puget sound and its tributary streams. The information obtained has been furnished to the joint commission and has been used in its report. The movements of the sockeye in the north end of the sound were studied, particularly among the San .Inan Islands, ehiefly to determine whether many of that species run into streams llowing into the sound from the State of Washington. 
The principal rivers examined were the Nooksack, Skagit, Stillaqualmish, and Snohomish. The time was too short to permit an exhaustive study of the questions involved, but enough was done to show that most of the rivers flowing into Puget Sound from the east are salmon streams of considerable importance. 'This is particularly true of the Skagit. The sockeye runs into this river iu large numbers, and there are important spawning-beds of this species in its headwaters. The State of Washington has recently estahlished, and is now suecessfully operating, a hatchery for this species on Baker Lake, one of the upper tributaries of the Skagit.

The height of the run of sockeye salmon in 1896 at the San Juan Islands was from August 20 to 28. The run was regarded as unusually large in view of the fact that this was an off year. Nothing definite was learned regarding the occurrence of the sockeye in any streams except the Skagit, nor whether it is found in any of the npper tributaries of the Skagit except the Baker. The Baker liver has a lake in its upper course which can be reached by the sockeye.

So far as is yet known, this species sparns only in such streams as lave lakes at their headwaters, and the spawning-beds are found only in the streams tributary to the lakes or in the lakes themselres. Several streams tributary to the northern part of Puget Sound contain lakes in their headwaters, and it would prove interesting and valuable work to determine accurately the distribution of the sockeye in this region.

All the other species of west coast salmon are found here in large numbers. The chinook first appear, then the silver salmon and steelhead, and still later the humpback and the dog salmons. The Nooksack is the principal river frequented by these species. The silver, humplack, and dog salmons are said to ascend both forks of this river.

The actual or even relative abundance of the different kinds of salmon and their distribution in the rivers of western Washington is not well understood, and scarcely anything is known regarding them after they enter the rivers.

\section{LAKE WASHINGTON.}

In February, 1889, the Inited states Fish Commission planted :37,000 fry of the common whitefish (Corgonus clupeiformis) in Lake Washington at Seattle. In June, 1896, Mr. A. B. Alexander visited this lake and began a series of observations for the purpose of determining the results of this planting of fish. After a few observations he was called away to other work, but returned and again took up the inquiry November 23, continuing it to January 10 following.

General description of Lake Washington.-This lake is situated in King County, Washington. Its greatest length, which lies nearly due north and south, is 181 miles, and its greatest wilth, from Mercer Slough across Mercer Island to the west shore, is about $4: 3$ miles. The greatest width of open water is about half a mile north of Mercer Island and is $3 \frac{1}{2}$ miles. The narrowest channel lies between Mercer Island and a point on the east shore about $: 3$ of a mile north of Mercer Slough. The eity of teattle is situated upon the rest shore about equally distant from the north and south ends of the lake. There are numerous bays and indentations, which give the lake a total shore-line of about 58 miles. The lake has an elevation of 34 feet above low tide at Seattle. The principal ontlet is Black liver, at the extreme sonthern end of the lake. This river is $2 \frac{1}{2}$ miles long, and unites with White River to form Duwamish River, which flows into Elliott or Duwamish. Maly a short distance south of Seattle. $\Delta$ bout a half mile below the lake Black River receives the Cedar River from the east. 
A few years ago a channel was eut from Union Bay through Lake Union to the sound. Considerable water flows through this channel and small boats are able to pass through it.

At the north end Lake Washington receives Squak Slough, which is the ontlet of Lake Sammamish. This slongh runs in a tortnous channel through low, marshy ground, its width varying according to the height of water in the lakes which it con. nects. When the water is very high the slough overflows and covers the low land ou either side.

During heavy rain the Duwamish River is unable to carry off readily all the water brought down by the White, Cedar, and other streams, and as a result Black River becomes, for the time being, an inlet instead of an outlet of Lake Washington. The lake therefore rises perceptibly, the intlowing water from Lake Sammamish is held back, and Squak Slongh overflows the adjacent lowlands.

Lake Washington is a beautiful body of water, surrounded by high hills from which a fine view of the surrounding country may be hat. The Cascade Mountains are plainly seen to the eastward and on the south Monnt Ranier comes into conspicuons view. In many places steep banks make down to the water's edge, indicating deep water. Nearly all the hills are corered with a dense growth of trees, escept where clearings have been made for homes and settlements. The shore line in nearly all parts is fringed with a dense undergrowth of brush and small trees; tule grass is found at every low point and slight indentation. Small trees along the shore interfere with the hanling of seines, and only limited collections can be made. In November and December a large amount of decayed vegetation covers portions of the shore. In summer various forms of minute animal and plant life inlabit the water.

Seine-hauling grounds.-Only in a few jlaces along the shore of the entire lake is the bottom suficiently free from suags, fullen trees, and other material to permit the successful hauling of nets. On the west sicle of the lake, abont ' 2 miles above Union Bay, is a long stretch of sandy shore mixed with fine gravel; in June, 1896, several attempts were made to haul a seiue here, but on account of the many obstacles no fish were taken. On the east side, at Hunter Point, is a comparatively good ground, but tule grass grows in considerable rpuatities, thongh by wading out and bending it down where the seine is to be landed fairly good results can be obtained. Several hauls were made here and a number of fish taken. In fall and winter there is a great scarcity of life here, as several trials demonstrated. From IIunter Point southward for about $2 \frac{1}{2}$ miles the shore makes down to the lake with a gradual slope, but owing to the great amount of vegetation that extends in most places into the water, it is almost impossible to use a seine. This also may be said of Hercer Slough and the shore farther south. On the east side of Mercer Island the bank is usually quite steep; on its west side the land is more slopiug. The water all round the island is deep. In the extreme southern portion of the lake, in the vicinity of Renton and Black liver, the land is marshy and filled with small sloughs. The bottom is of soft mud.

On the north and west sides of Lake Washington, from Webster Point to Sand l'oint, are scattering sandy patches, but ouly in a few places can a seine be hauled, owing to a thick growth of serubby trees at the water's edge. High banks in most places overhang the shore line. Northward from these points the land is more sloping and in some places comparatively level. Rocky and gravel beaches crop out from the banks in many places and in a number of indentations the water makes oft shallow 
from the shore a distance of 50 feet or wore. The bottom here is very muddy and covered with tule. The shore on this side of the lake is thickly stremn with logs, slabs, and small tloating débris. Few rocks are noticeable, and none at any great distance from shore.

The sandy and gravelly beaches referred to on the west side of the lake below Sand Point are usually narrow; only in one place observed is the beach over 10 feet wide; here the width from the water's edge to the bluti' is about 30 feet. The clear ground indicates a smooth bottom, but stumps of trees and broken limbs prevent seine collecting. These beaches are formed by wave action, the water having washed away the base of the bluffs, learing a deposit of sand and gravel. In many places, particularly on the west side of the lake, bushes and small trees have taken root in the sand and gravel deposit. Only in a few instances does the sand and gravel formation extend any great distance below the water's edge; 30 or 40 feet from the shore is soft muddy bottom. As is inclicated by the high perpendicular bluffs, the beaches make oft at a sharp angle, deep water being found a short distance from the shore. As a whole, the shore of Lake Washington is not well adapted to collecting with a seine.

Depth and character of bottom.-Soundings were taken at different times and in various parts of Lake Washington. It has a nuiform deptl in the center, ranging from 138 to 222 feet. The character of the bottom is generally muddy. Off the mouth of Union Bay and near the boathouse at Madison street sandy bottom was found. Otit and in the vicinity of Sand Point, 3. miles farther north, the bottom is composed of sand and gravel. This kiud of bottom does not extend very far from the shore, from 500 to 800 feet being about the limit. For nearly '2 miles south of Saud Point there are a number of sandy places along the shore, mostly covered with an undergrorth of bushes. In all other parts of the lake examined the bottom is chiefly of soft mud. On the east side of the lake, sonth of Iunt Point, the water is quite deep close to the shore; this is also true of the rest side, sonth of Sand Point, and in many other parts. A depth of from 500 to 1,800 feet was reported off the northern end of Mercer Island and in the vicinity of Hunt Point. Comparatively deep water was found oft these points, as will be seen by referring to the map, but no such depths as had been reported. Abont 1 mile along the shore above Kirkland a plateau from 60 to 100 feet wide, covered with regetation, makes off from the shore. The water varies in depth from 10 to 20 feet, but suddenly deepens into 60 and 70 feet when the edge is reached.

Temperature of water.-It will be noticed in the table of temperatures that near the shore on the east side of Mercer Island the temperature of the water at the surface varies considerably from that taken a short distance toward the middle of the channel. A difference of 210 is recorded, the bottom temperature in both soundings being the same. In no other part of the lake was such a marked difference found. Several tests of the water were made within a radius of 100 feet or more, all with the same result. A few lundred feet from this position, to the uorth, south, or east, $47^{\circ}$ was found at the surface. It is said that thermal springs occur in this vicinity in a number of places. The temperature of the water at the bottom, howerer, does not indicate their presence. The lowest temperature found in the main body of the lake was $441_{2}^{\circ}$, and the highest $482^{\circ}$; the first in depths of 180 and 190 teet. In Union Bay, in 14 feet of water, a temperature of $41^{\circ}$ was recorded both at the surface and the bottom. This low temperature was due, no doubt, to the cold weather, which at this time was quite severe. At no other place was such a low temperature found. 
The temperature of the air seemed to have no perceptible daily effect on the water in deep portions of the lake. From Lovember 23 to 30 the air varied but little, from $20^{\circ}$ to $29^{\circ}$ being about the minimum and maximum height. Uuring December from $45^{\circ}$ to $45^{\circ}$ was the approximate daily temperature.

In depths over 150 feet the air ceased to have an effect on the water much below 40 feet from the surface. In a few places 50 feet below the surface was reached before the temperature remained constant. In depths less than 100 the temperature was found constant about 30 feet below the surface.

It will be noticed that in a number of places in depths ranging from 40 to orer 200 feet the temperature both at the surface and bottom is the same. Why this should be, when only a short distance away the difference between the surface and bottom is a degree or more, is not easily explained.

Hang of the temperatures amd soundings takeu are recorded in the folloming table:

Soundings and temperatures taken in Lake Thashington.

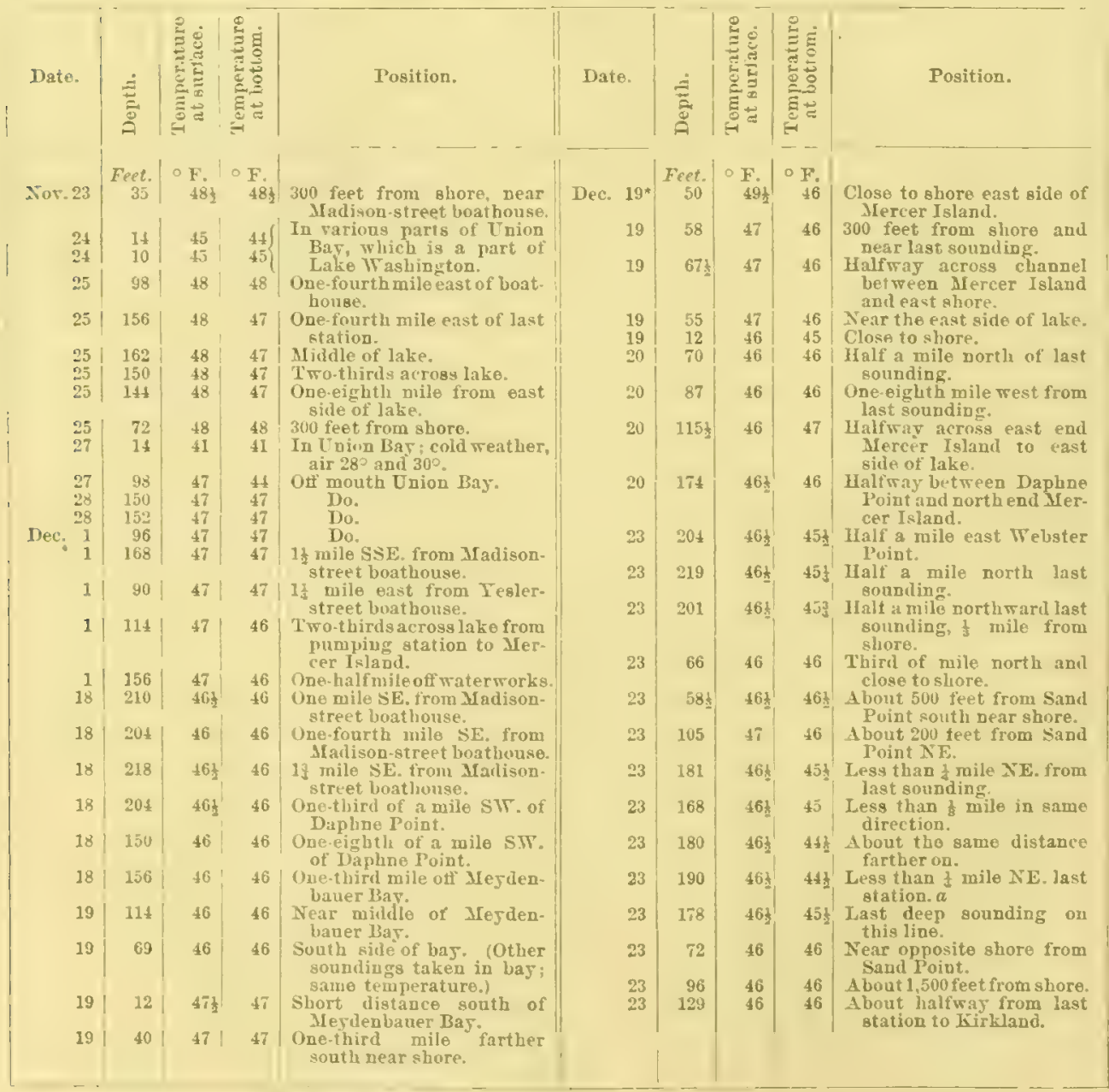

a Said to be thermal springs in near ricinit 5 , which may account for the change of temperature. 


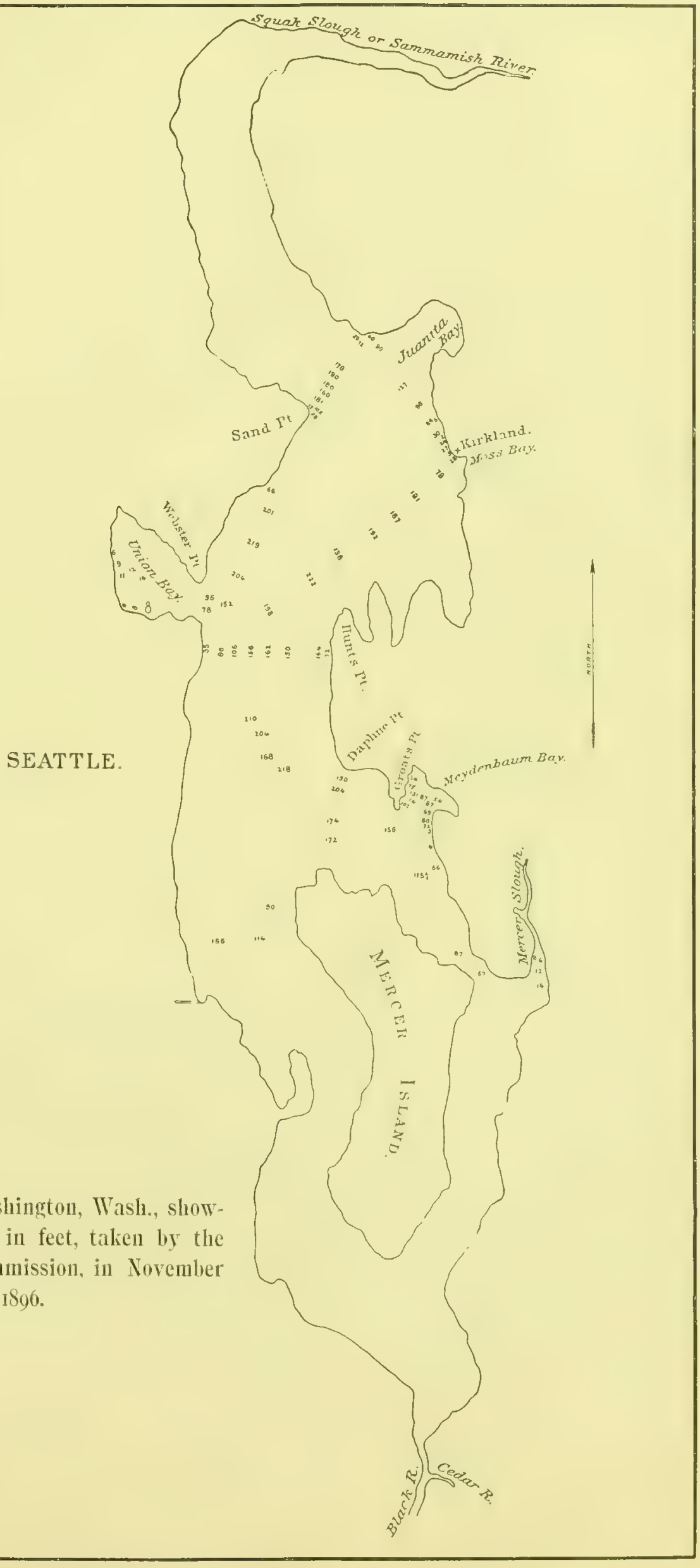

Map of Lake Washington, Wash., showing soundings, in feet, taken by the U. S. Fish Commission, in November and December, 1896 . 

During the winter months short periods of cold weather sweep over this part of the Northwest, but not sufficiently severe for ice to form in the main portion of Lake Washington. Occasionally skim ice appears on the margin of the lake in sheltered places covering small areas.

Trials with gill nets and other apparatus.-On November 23 the first trial with gill nets for whitefish was made in 35 feet of water, 300 feet from the shore, at a point where it is said that an example of this species had been taken. Two nets were set, and remained down 48 hours. They were visited on three different occasions during that time, but no fish were found in them. The reason for setting nets in such shallow water for whitefish, was in compliance with a request made by the person who claimed to have canght a specimen on the above-mentioned wround in the fill of 1592. It was taken on a hook, which throws considerable doubt as to its being the true whitefish. So far as we have been able to learn no other specimen has since been seen.

On November 24 three more gill nets were set about $1 \frac{1}{2}$ miles from first position on the south side of Union Bay. Here also whitefish had been reported. Depth of water, 15 feet; temperature of water at bottom and at, surface, 450 ; bottom muddy. These nets remained in the water three days, and rere visited each moruing. No fish were found in them.

On November 26 three nets were set at the head of Union Bay, in 10 feet of water, close to the shore, where fish are said to be plentiful in summer; also two other nets near outlet or portage, about three-quarters of a mile farther south. In this place anglers have good tishing, and it was thought that if fish were running in any considerable numbers the nets would be likely to take samples of different species. The nets set at the head of the bay were taken up the following morning, nothing being found in them. Those set near the outlet remained down two days, and were visited each morning. The second morning one cut-throat trout aud one chub were taken from them. During the time the nets were down a number of cut-throat trout, chub, and suckers had been taken on hook and line. Sounding and collecting with surface tow net had also been carried on whenever the weather permitted.

On November 27 . three gill nets were set near the bottom, off the mouth of Union Bay, in 18 feet of water, bottom hard sand, where they remained two days. Nothing was found in them when taken up. It is reported that large numbers of fish pass over this ground, and it was thought that our efforts would be rewanded by a few specimens. The result of this trial indicates that at this season fish do not move in great numbers. The same nets were set in 96 feet of water about a quarter of a mile farther ofi shore, where the bottom temperature was $3 \circ$ warmer than at last station. The nets were, as before, set near the bottom, but without result. Had whitefish or other species been traveling over this ground a few would have been captured.

A small creek that flows into the head or western part of Union Bay was next investigated. This creek is said to abound with trout in summer and with redfish in early fall. The water in the upper part of the creek flows with considerable velocity over a gravelly bottom. It is from \pm to 5 feet wide in most places, and about 7 or 8 inches deep; there are a few pools whose depth is nearly 2 feet. The creek is largely fed by seepage from the surrounding hills. At the time of our visit the weather was cold and the ground covered with snow, and in many places ice lrad formed. The stream empties into a marshy lagoon where it finds its way, through several smaller ones, into Union Bay. 
Repeated trials with a small collecting seine at the month of the ereek rrere made, but nothing was taken in it. Only one fish, thought to be a redfish, was seen, and it escaped under a fallen tree. Unsuccessful hauls mere also made from a half to threequarters of a mile upstream. Hook-and-line fishing was also tried, with the same result, salmon eggs leing used for bait. At the mouth of the creek a salamander was found, and this was the only form of life scen, except the supposed redfish.

On December 11 gill nets were set in a number of places, from a half to threequarters of a mile apart, in Squak Slough at the head of Lake Washington, in 9 and $\mathbf{1 0}$ feet of water. They were visited twice in 48 honrs, nothing being found in them. The bottom temperature in the places where they were set was $44 \frac{1}{2}$, surfice 45.50 . During the entire investigation the water in the slongh was unusually high, and this probably had a great deal to do with the scarcity of fish here, for at snch times, instead of following the main channel, fish would naturally scatter over a large area, thereby greatly lessening the chances of taking them. Troll fishing was tried, but with unsatisfactory results.

Nearly all of December 18 was spent in sounding and taking water temperatures. In the afternoon four nets were set on the uorth side of Meydenbaner Bay; depth, 102 feet; bottom and surface temperature, $46^{\circ}$. Nothing being in the nets the following morning they were taken up and set ou the north side of Mercer Slough, nearly 3 miles farther down the lake. A trial for 48 hours resulted in the capture of one female cut-throat trout, the eggs of which rere approaching a state of ripeness. Two other specimens subsequently taken showed the same amount of development. Several creeks on the west side of the lake were investigated but no fish mere found.

IITitefish.-There is no satisfactory evidence of whitefish ever having been caught in Lake Washington, though sereral persons claim to have seen them. One person says in the fall of 1892 he caught a specimen, but no accurate description was giren as to its shape or color, and Prof. O. B. Johnson and State Fish Commissioner James Crawford doubt whether it was the genuiue whitefish, and believe that the whitefish planted in the lake no longer exist. The investigation strengthens this opinion. The Columbia chub (Mylocheilus caurinus) is a common species in the lakes of this region, and is by many people known as "whitefish." It is not improbable that all the so.called "whitefish" which have been reported from Lake Washington were really this species of minnow. Williamson's whitefish (Coregonus williamsoni) doubtless occurs bere, but no specimens trere seen.

Other nishes of Lake Wrashington.-The various species of fishes collected during these investigations, as well as all other species linown to occur in Lake Washington, are listed in another part of this report. The principal species are the cut-throat trout, Columbia liver chub, squawtish, Columbia River sucker, a blob, two or three other species of Cyprimide, and the redfish. Salmon are said to enter the lake through Black liver early in the fall, but none was seen. They are probably the large form of the redfish or sockeye (Oncorhynchus nerke). Redfish are said to run up) into shallow places during the latter part of October and a part of November, but repeated trials resulted in collecting only a few specimens. Those familiar with the different runs of fish on the lake attribute the scarcity of redfish this season to high water. In Squak Slough, where they are said to run in great numbers, not a specimen was seen or taken, though before the water began to rise in the slough a considerable body of these fish was reported as passing through. Black bass are occasionally 
taken in Lake Washington, and they are at times quite plentiful in Lake Union, which supplies all the black bass to the Seattle market. The yellow pereh (Perea flacescens) has also become well established in this lake.

\section{LAKE SAMMAMISH, WASHINGTON.}

While engaged in carrying on observations upon Lake W'ashington Mr. Alexander made a trip, December 31 to Jauuary 6 , to Lake Sammamish, a short distance to the eastward. He gives the following account of this lake and the investigations:

This body of water lies parallel to Lake Washington, the two lakes being separated by a hilly strip of country, the most narrow part being $3 \frac{1}{2}$ miles across. The greatest distance between the lakes is 8 miles.

Lake Sammamish is 38 feet above low-water mark at Seattle and 4 feet abore Lake Washington. The land separating the southern portion of the bodies of water might be termed mountainous; many of the hills rise from 1,000 to 1,500 feet from their base, and are covered mostly with a dense growth of trees. A road cut through the forest from the west shore of Lake Sammamish to the east side of Lake Washington is traveled considerably during the summer months. A boat connecting at the end of the road carries passengers across Lake Washington and lands them in Seattle much sooner than if they traveled by rail.

The length of Lake Sammanish is S miles; its greatest width (about halfway between its north and south points) is 1 ? miles. Its narrowest part is near the northern end, a little over half a mile from shore to shore. From Inglewood, in the northern part, to Mowohan on the south it has a nearly uniform width of about $1 \frac{1}{2}$ miles. It lies nearly in a north-and-sonth direction; a line beiug dramn north from the south end would strike 1 mile east of its most uorthern part. The Seattle and Lake Shore

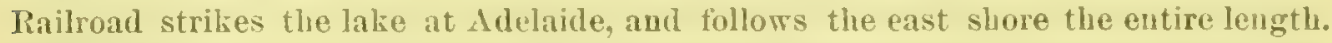
Three smail towns are situated near the shore on the east side. The most important is Monohan, near the south end. On the west side a number of settlers have made considerable clearings. Opposite Monohan is a huge pile of sawdust, which extends for a considerable distance into the lake, and when the water is rough small chunks of it are washed away. It being water-soaked, most of it that falls into the lake immediately sinks. The sawdust coming from the mill at Monohan is burned.

Toporraphy of the shore.-The shore in most parts of Lake Sammamish is composed chiefly of sand and gravel, forming numerous beaches. These beaches, when the water is at its normal height, are exposed. At the time of our visit to the lake (December 31 to January 6 ) the water was about 4 feet higher than in summer; it had then fallen 2 feet since the middle of December. Judging from the condition of the lake at high water, the beaches when exposed must be from 8 to 12 feet wide, measuring from the water's edge to the bank. In most places they extend oflshore at a sharp angle. Except in a fer places, where the sandy and gravelly beaches appear, the bottom makes off gradually and its character is either hard or soft mud. The southern shore of the lake is skirted by low marsh land, which extends from the southwest to the southeast side. Here sereral small creeks empty into the lake, which, no doubt, have contributed largely to the marsh land.

The hills bordering the southern portion of the lake descend with a more gradual slope than those on the east and west sides. The land in the immediate ricinity of the lake is not more than 4 or 5 feet higher than the level of the water, gradually 
rising for a distance of about a mile before the foothills are reached. Many portions of this slope have been cleared. Off the points in this part of the lake, from 30 to 40 feet from the shore, thick clusters of tule are submerged in water from 7 to 10 feet deep. Later in the season a large portion of the ground in which this grass grows is exposed. Soundings were made along the outer edges of these strips and points without finding any indications of hard bottom.

On the east and west sides of the lake the steep hills rise within a short distance from the water; in many places projecting points and bluft's rise very abruptly, with little or no shore line at their base. The bottom close to these projections is hard, being composed of a mixture of sand, coarse gravel, and small stones. The hilly land is covered with a deuse growth of trees, extending to the water's edge, and at times when the water is high it is very difticult to walk any distance along the shore without swinging from one bough of a tree to another. When the water is low or at its average height the sand and gravel beaches here are bare.

At the foot of the lake, on the northeast side near Squak Slough, a low point of laud extends for a consilerable distance southward. From this point south, a distance of nearly 2 miles, the shore is composed of sand and gravel beaches. On the west side and north from where the last line of soundings was begun the hills gradually descend to the shore, and in a number of places toward the foot of the lake the land is quite level. The shore line along the northwest and northeast portions of the lake is covered with logs, slabs, and pieces of timber, refiuse material that comes from the shingle mill situated near the north end and the sammill near the sonth end. The greater part of this material is found in the northeast portion of the lake, being forced there by the southirest winds.

On the west side of the lake, near its southern end, is a submerged forest, about half a mile long north aud south, extending nearly a third of the distance across toward the east side. The northern end of the forest commences near the pile of sawdust alrearly mentioned. It runs parallel to the shore and is separated from it by a distance of about 600 feet. Duriug the summer months it is said that the tops of many of the trees project above the water from 1 to 2 feet. 'The lake then is much clearer than in winter, and on a bright day, when the water is smooth, a large portion of the forest, according to the statement of people living at the lake, is plainly visible. Owing to the muddy condition of the water, caused by the heavy lains, we were mable to find any of the trees. Many theories are advanced by people living near the lake as to how the forest came to be in its present position. The most common theory is that at some remote period a gigantic landslide oceurred and the displaced material found a resting-place at the bottom of the lake. Considering that the nearest hills where a landslide of such magnitude could have started are situated nearly 2 miles from the lake with compuratively level combty lying between, this theory is not altogether tenable. A large tract of land becoming detached from the side of a mountain and carried aloug rapidly by its own weight a distance of a mile or more from its starting point would by the time it reached its destiuation be a huge mass of trees, earth, and stones. The trees would be more or less broken, and not left standing in an upright position. It is also likely that if the forest in question had suddenly been detached from the side of one of the adjacent mountains it would have stopped on arriving at comparatively level ground, but instead we find it deposited a long distance fiom hllls of any great size. If, however, such had been the case, and it was forced 
along over level ground, we might expect to find that part of the lake where the landslide was deposited more shallow than elsewhere; but, on the contrary, we find a depth of water varying from 50 to 70 feet, which corresponds with depths found in other parts of the lake the same distance from the shore. It seems more reasonable to suppose that at some distaut period the ground on which this forest grew, subsided. This, in a measure, would account for the trees being left standing in their natural position. Not having seen any portion of the submerged forest, we are not able to state from personal observation anything concerning it, only stating what luas been given by several reliable parties. Efforts were made to locate some of the trees, but none of them could be found with the sounding line.

Depth of water and character of bottom.-Lake Sammamish is quite uniform in depth, varying from 70 to 90 odd feet in the middle and from 35 to 50 feet near the shore. The deepest sounding was found near the middle of the lake, about halfway across from Hattie Bell Springs to the west shore. A line of soundings run across the upper part a short distance below the shingle mill corresponds nearly with the line across the south end of the lake. In no part of the lake examined are there indi. cations of plateaus or shelves making off' from the shore. Only in a few places was shallow water found, and this exteuded but a short distance from the shore. In nearly all parts of the lake along its margin the bottom drops off' suddenly, the water being deep enough for boats and small steamers to lie alongside and discharge freight or passenger's.

From 80 to 100 feet from the shore is the average distance where the sand and gravel merge into the hard or soft mud. A number of places, however, were found where sand and gravel bottom extends from 1:5 to 300 feet into the lake; one of these places is on the west side, opposite Hattie Bell Springs, and the other off the wharf on which the sawmill at Monohan is built.

At the foot of the lake, above the shingle mill, the bottom is very soft and in the center between the east and west sides the mud is said to be several feet deep, and this statement is probably not exaggerated, for in running the line of soundings which ends just below the shingle mill the sounding lead, nearly all the way across, sank into the soft bottom a foot or more.

Inlets.-Numerous small creeks empty in to the lake both on the east and west sides, but the discharge of water is not great even during the rainy season, and in summer many of them dry up, they being feel by the drainage from the surounding hills. The principal inlets are Issaquah and Manner creeks, which enter the lake on the south end. The main portion of the first creek is " 2 miles long and the second about 3 miles, each having several branches from $\frac{1}{2}$ to $2 \frac{1}{2}$ miles long. The water in Issaquah Creek is said to be very clear dnring the summer and fall months, or was previous to the coal company using the creek as a dumping ground for coal screenings, since which time the water has become muddy. There are a number of coal mines in this region, and the people complain of the screenings from them being dumped into the creeks, thereby doing considerable injury to the fishing. grounds.

Outlet.-Squak Slough, or Sammamish River, is the only outlet to the lake. This at times is not large enough to prevent the water in the lake from rising rapilly, and when Lake Washington rises at the same time, which is usually the case, and forces the water from the slough into Lake Sammanish, both lakes rise rapidly. At the 
time of visiting Lake Sammanish the water had overtlown the channel of the slongh from a quarter to a lialf mile; its average width for the part visited is less than 100 feet, in some places not over 50 feet. Its length is about 12 miles; its course, as indicated on the inap, is very crooked, and it is navigable for small craft only.

Temperatures.-The water temperatures during our investigation varied but little, and in mauy parts of the lake there is no difference. In the first line of soundings run across the like the surface and bottom temperatures were the same. The weather at the time was rainy, misty, and cold. In the second line a difference of 10 was found in two places, each in a lepth of 90 feet. At the surface the thermometer registered $45^{\circ}$ and at the bottom $44^{\circ}$. In the third line the depths were from 33 to 92 feet, with $n o$ variation in temperature. The fourth line, run the same day, shows in eight different soundiugs $45 \circ$ at the surface and $443^{\circ}$ at the bottom. The fifth line, run across the bead of the lake, showed no difference; but in a number of soundings taken on the west side, near where a small brook empties into the lake, the water was 10 warmer at the surface than at the bottom. The depths here were comparatively shallow. The last line of sonudings run, which was across the foot of the lake, also showed the water to be 10 warmer at the surface than at the bottom. 'This difference may possibly have been because the weather was warm and pleasant, while most of the time, when the other sonndings were taken, it was rainy and foggy and the temperature of the air from $44^{\circ}$ to $50^{\circ}$. On this day, January 6 , it registered $60^{\circ}$ a greater part of the day.

Where the water at the surfice mas warmer than at the bottom it was found that the warm water extended from 5 to 8 feet below the surface; where the temperature at the bottom was warmer than at the surface the water was constant from 15 to 18 feet from the bottom. The thermometer ras let down at varions depths, in most cases at intervals of 10 feet, no variation in temperature being noticel until the above distance from the bottom was reached. In a few places, however, within 10 feet of the bottom the water remained constant.

Condition of water.-In the full and winter, when the lake is high, the water is considerably discolored by vegetable matter and sediment washed from the surrounding hills and brought down by the swollen creeks. This gradually disappears as the rain ceases, after which the water becomes clear. 'The fish then bite better than at any other time, there being less food in the water for them to subsist npon.

Lake Sammamish, like Lake Washington, never freezes over. When the weather is unusually severe skim ice sometimes forms near the edge in shallow places, but the deep water does not freeze.

Fishing trials.-From December 31 to January 6 sounding, taking temperatures, collecting with surface tow net, and fishing with gill nets and troll were carried on. The weather most of the time was stormy. Fishing with gill nets was unsuccessful. They were set in varions places and in different depths, visited twice each day, and in the evening set in a different place. Inquiries nere made of fishermen as to where fish would most likely be found, but nothing was caught. A trawl was the only stationary apparatus used that raptured anything, and this caught only one chub and a blob.

Fishing with troll line was fairly successful, five cut-throat tront being taken. The weather was unsuitable for this kind of fishing. To meet with good results the weather should be moderate and much wamer than it was during the time these trials 
were made. Fishermen say that in summer, and at other times when the weather is pleasaut, it is comparatively easy to catch from twenty-five to thirty trout in a day by trolling.

Tront would bite only when the wind was light and the lake smooth. During the day, whenever there was little wind stirring, they could be seen jumping or breaking water in all parts of the lake, but they did not bite as ravenously as was expected, probably on account of the creeks having brought down considerable quautities of vegetable and other matter, such as they may feed upon. Fisbermen elaim that the fish never bito well when the lake is high. Several good examples, hotrever, were canght in the few trials made. When fish are at all inclined to bite, a trawl will usually pick up a variety of species. The traw1 set (90-odd hooks) was baited with fresh chub and meat, and good results were expected of it, bnt in this we rere disappointed.

The trout taken by trolling were cauglit close to the shore, that being the part of the lake where the fishermen troll when the water is high. Fish were breaking water in the middle of the lake, but none was captured. In summer good fishing is to be had in all parts.

Methods of fishing.-The principal method of taking fish in Lake Sammamish is by trolling, though good catches are sometimes made with set line and with rod and line. In summer the lake is quite a resort for sportsmen from Seattle. No commercial fishing is carried on, all fish caught being locally consumed, except the fer taken to Seattle by people belonging there.

Kinds of fish.-The economic species of fish fomd in Iake Sammamish are the same as those of Lake Washington, namely, cut-throat trout, "grayling," or redfish, and salmou. No examples of the last two species were found, they haviug disappeared shortly after the water in the lake began to rise in November. About that time it is said that redfish were plentiful in Squak Slough and in the creeks at the head of the lake. Salmon run with the redfish, but only scattering individuals are taken. No information could be obtained as to what kind of salmon enter the lake; but the dog salmon aud an occasional steelhead probably find their way into this body of water. During the redfish run the neighboring Indians do considerable fishing on Squak Slough, and lay in their supply for winter. Only one person living near the lake claims to have caught a whitefish in it, and he was not sure that the specimen was a genuine whitefish; others who saw the fish say that it was not, but admit that the fish differed from any previously taken in the lake.

Spuoning habits.-People living near Lake Sammamish say that the cut-throat trout spawn in the spring and the condition of most of the specimens indicates that they are correct in their observations. One taken in Lake Washington contained eggs well advanced, but this fish would hardly indicate a difference in the spawning season between the tro lakes, as fish can easily pass from one lake to the other. The redfish probably spawn some time in November, that being the time they run in greatest numbers. Only a fer specimens were taken, and they were not sufficiently developed to form an estimate as to the month in which they spawn, bnt people who have caught and observed the redtsh, hoth in Lake Sammanish and Lake Washington, believe that the spawning season is from the latter part of October to the middle of November. To gain a better knowledge as to the habits of this sprecies in this region some person should be stationed at these lakes early iu the fall, before the rainy season comes on. 
It is said that redfish run only for a short time, that they disappear as sudilenly as they come, and few are seen in any part of the lakes after the rum is over. Almost every person with whom we conversed on the subject expressed the opinion that the redtish, or "grayling," as they are commonly called, annually come in from the ocean; but some believe that they never leave the lake, but retire into the deep parts of the litke as soon as the spamning season is over. Positive knowledge on the subject is lacking. The few specimens taken in Lake Washington would hardly warrant an opinion to be formed as to their habits in these lakes. It would be necessary to observe a considerable number from the time they first appear until they leave.

Surface material._Collecting with surface tow net was carried on at different intervals. As was the case on Lake Washington, surface life was found most abundint in the evening; at other times a trial of 15 or 20 minutes wonld result in a small quantity of material.

Depth of water, temperature, and character of bottom of Lake Sammamish.

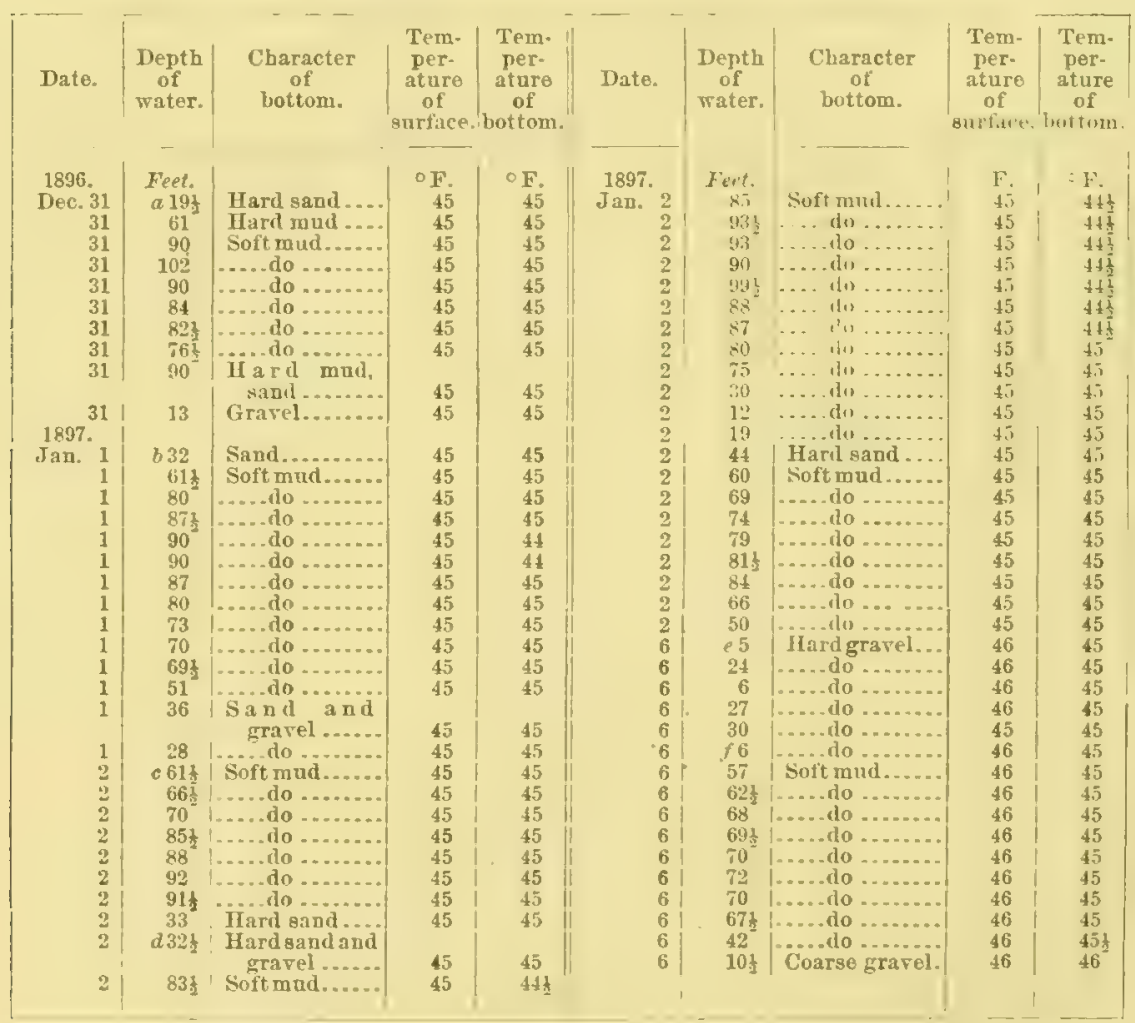

a A bout 20 feet from brilge; first line sounding. $b$ Second line of soundings 250 teet from sammill. $c$ Commencement of third line of soundings.

dCommencement of forrth line of soundings. e Soundings close to a brook. $f$ Sixth live of soundings 20 feet from shore. 
Lake Sammamish, near Seattle, Wash., showing soundings taken by $U$. S. Fish Commission, in December, 1896 , and January, 1897.

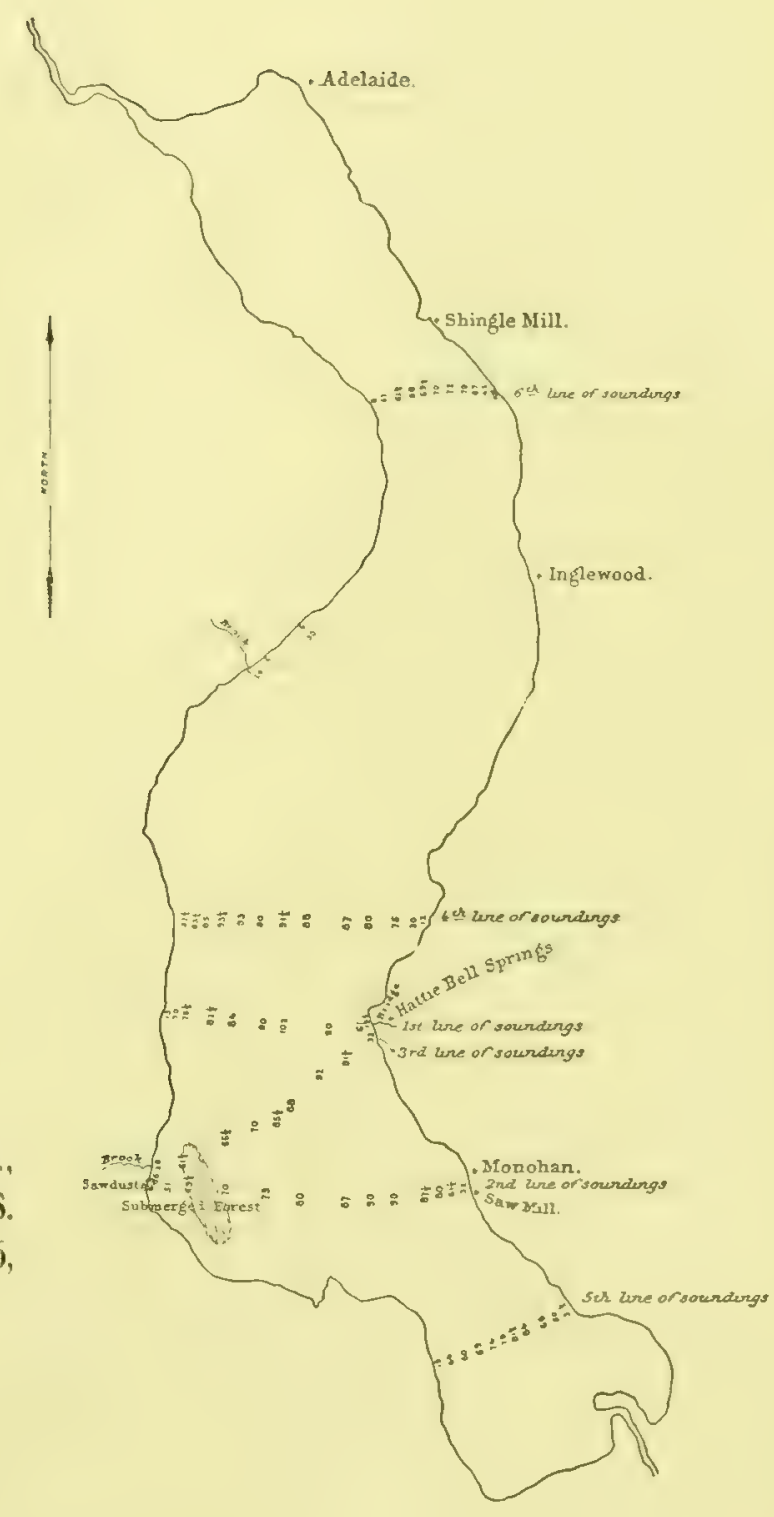





\section{LAKE UNION, WASHINGTON,}

The following notes on Lake Union have been furnished by Mr. Alexander:

'This body ot water lies close to the city of Seattle. Its length, measured in a straight line from north to south, is $1_{\frac{1}{2}}$ miles; width, halfway between tho north and sonth ends, three-quarters of a mile. Branching out from the head of the lake are two arms, one leading to the northeast aud the other to the northwest. Measured from the foot of the northeast arm the lake has a length of $3 \frac{1}{4}$ miles.

Lake Union has a quite uniform deptlı in the center; the greatest depth, 48 feet, is found in nearly all parts of the main body a quarter of a mile from the shore. In the northeast arm the soundings varied from 24 to 27 feet. Near the shore, except in places where there is marsh land, the depth is from 18 to 25 feet. In the south end of the northeast arm the land is marsiyz; also of the point extending into the northern part of the lake between the two arms. In most other parts grass laud extends down to the water's edge with a gradual slope. On the east side the land is quite level and covered with willow and other trees. This strip of land extends back from the lake for a considerable distance, when it suddenly runs into high blufts.

The laud surrounding the lake for the most part is high and was at one time heavily wooded, but now only small clumps of trees are left standing, most of the once great forest having given way to town sites aud buildings. Skirting the north shore rums the seattle and Lake Shore Railroai. The shore is thickly settled, exeept on the east and northenst sides.

The bottom in nearly all parts is mud, in some places intermingled with fine sand.

From the $2 d$ to the 8 th of December gill nets were set in ten different places, taking 4 salmon, 1 cut-throat trout, and 2 suckers. In no place were the nets down less than 24 hours, and in one place they remained down 72 hours. They were set in places best adapted for this kind of fishing and where black bass had been eatught in greatest numbers. Trolling for black bass was carried on at different times, but nothing was caught. The season was too late for them, but it was thought that the gill nets might capture a specimen or two.

During the summer black bass are firequently taken by trolling, and it is reported that they are sometimes taken in nets seeretly set for their capture. This method is illegal, but is carried on to some extent. Only a few black bass have been caught in Lake Washington, and those planted in this lake in 1890 soon found their way into Lake Union, where they are said to be quite plentiful during the summer months. Why they should find the water in Lake Union better suited to their wants than where they were planted is not easily explained. It can not be due wholly to the difference in the coudition of the water, for Lalke Washington lareely supplies Lake Union. The theory that presents itself to aceount for these fish being fouml in Lake Union and not in Lake Washington is that in the former lake small surface life is much more abundant. The collections made in the two lakes show a considerable difference in the amount taken in each trial.

In winter the temperature of water of this lake is several degrees colder than that of Lake Washington, thongh ice seldom forms, and only when the winter is umusually severe does the lake freeze over; it is probable that in summer Latie Union is the warmer, it being shallow. 
Temperatures taken in Lake trnion.

\begin{tabular}{|c|c|c|c|c|c|c|c|c|c|}
\hline Date. & Time. & I) pth. & $\frac{\text { Tempe }}{\text { Surface }}$ & $\frac{\text { rature. }}{\text { Isottom }}$ & Date. & Time. & Depth. & \multicolumn{2}{|c|}{$\begin{array}{l}\text { Temperature. } \\
\text { Surfacel liottom. }\end{array}$} \\
\hline $\begin{array}{r}1896 . \\
\text { Dec. } 2 \\
3 \\
2 \\
2 \\
2 \\
2 . \\
2 .\end{array}$ & $\begin{array}{r}9.00 \text { a.m } \\
11.00 \text { a. m } \\
3.20 \mathrm{pm} \\
3.30 \mathrm{pm} \\
3.40 \mathrm{pm} \\
4.00 \mathrm{pm}\end{array}$ & $\begin{array}{r}\text { Feet. } \\
6 \\
21 \\
12 \\
48 \\
36 \\
24\end{array}$ & $\begin{array}{l}\mathrm{F}_{3} \\
42 \\
42 \\
42 \\
43 \\
43 \\
43\end{array}$ & $\begin{array}{l}F \\
44 \\
44 \\
42 \\
42 \\
42 \\
42\end{array}$ & $\begin{array}{r}1836 . \\
\text { Dec. } 2 \ldots \\
2 . \\
3 \ldots \\
3 \ldots \\
3 .\end{array}$ & 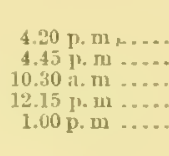 & $\begin{array}{c}\text { Feet. } \\
24 \\
27 \\
48 \\
4 x \\
9\end{array}$ & $\begin{array}{l}\text { oF. } \\
43 \\
42 \\
43 \\
43 \\
41\end{array}$ & $\begin{array}{l}\mathrm{F} \\
42 \\
43 \\
42 \\
42 \\
42\end{array}$ \\
\hline
\end{tabular}

SIUSLAW RIVER, OREGON.

In 1894 the State of Oregon erected a building ou the Siuslaw River at Mapleton: Oregon, with the intention of eondueting salmon-cultural operatious at that place. This building finally reverted to the original owner of the land upon which it was located. Believing that this station could be successfully and probitably operated, the owner, through Mr. L. E. Bean, of Mapleton, kindly offered its free use to the United States Fish Commission for that purpose. In response to this offer Dr. Meek and Mr. Alexander were instructed to visit the station and make such examination as would determine the probability of its being operated advantageously. The preliminary inquiry, made early in September, showed that it wonld be necessary to catch the fish at the fishing ground, several miles below the station, and retain them in boxes until ripe. It was thought that this could be doue and that the boxes conld be floated on the tide up to the station. This could be determined only throngh experimentation. Dr. Meek was therefore instructed to return to Mapletou and thoroughly test the matter.

General description of Sinslaw River.-The Siuslaw River is one of the short coastal streams in Oregon whose basin is confined entirely to the western slope of the Coast Range. From its month to its sonrce is a distance of about 100 miles. It drains a very broken country, which is quite heavily timbered. From the mouth of Wildeat Creek to near the month of North Fork the river flows throngh a canyon to 3 miles in width. The hills or mountains on each side of the canyon are from 200 to over 1,000 feet above the river and are very steep. At the mouth of Lorth Fork is a large area which is covered by water only at high tide. This region, linown as the mud flats, is on the north side of the river and includes most of the distance between Acme and Florence. At Florence the river turns nearly north and then curres slightly torard the west. 'The right-hand bank is, for the most part, a low bluff' of soft sandstone; the left is bordered by sand hills.

The Siuslaw River above the month of Wildcat Creek was not visited, but from what we were able to learn that portion is quite similar in all respects to the part immediately below that creek, except that gravel bars become much more frequent as you ascend the river. From the mouth of Wildeat Creek to the head of tide, a distance of about 24 miles, the bottom of the river is sandstone in sitn, over which, in many places, are scattered large, angular, somewhat water-worn, sandstone bowliers. The river above head of tide water is from 60 to 200 feet in width, and during the summer in many places the water is less than 2 feet in depth.

The canyon is cut through sandstone, which in some places is nearly horizontal, while in others it is tilted more or less, seldom more than 30 . The only portion noticed which showed signs of being metamorphic is a bluft on the right hand of the river between Seaton and Mapleton. 
The timber in the region drained by the Sinslaw is chielly tir, some cedar, hemlock, spruce, maple, and alder. Some of the alders are as mnch as 18 inches in diameter, and some of the fir trees a sliort distance rest of the summit of the Coast Rauge are very high. There is also in this region a very rich growth of ferns, chiefly the common I'teris. A large portion of the timber along the lower 30 miles of the Siuslaw was destroyed by fire some sixty years ago. This is being replaced by an undergrowth of tir, alder, maple, etc. The timber bordering the sand hills is mostly bull pine.

'The North Fork of sinslaw IRiver is much smaller than the main river. In the neighborhood of Minerv. the deeper holes in the river are from 20 to 50 feet wide, the shallow places connecting these holes being about half this wilth. Mong the river, for a distance above tide water of abont 8 miles, are many gravel bars orer which the water flows during the summex in depths rarying from a few inches to about 3 feet. The timber along the North Fork is similar to that on the main river, the under or smaller growth immediately on the banks being some denser. Very little timber along the North Fork below Minerva has been destroyed and scarcely none above that place. The water in North Fork is clear, though considerably stained by regetation, wuch more so than in the main fork.

The rater in the Siuslaw in the summer is moderately clear, thongh slightly discolored by vegetatiou. It also contains a fine silt or sediment of some sort, which collects on the web of gill nets. At tlood tide, about halfway betreen Florence and Irapleton, the water appears of a reddish color, apparently due to the mingling of the comparaticely fresh with the brackish water, the salt in the brackish water precipitating the clay sedinent in the fresher water. During the summer, at the head of navigation, the water at all times is too brackish for steamboat boiler use.

The heal of tide water is about half a mile above Seaton. About half a mile below Seaton is an islund in the river, on either side of which, at Iow tide, the water in the deepest place is less than 3 feet. Small steamers drawing about $3 \frac{1}{3}$ feet of water can not pass this island in summer except at from lalf to full tide.

Mapleton is 1 mile below Seaton. Below Mapleton in summer and at low tide the water in the shallow portions of the river is seldom less than 10 or 12 feet in depth. Seaton is properly the heal of tide water, Mapleton the head of navigation.

The river below Mapleton will average at least twice as wide as it does above it, and it varies in depth at low tide in summer from 10 to 12 feet to as much as 60 feet.

On October 16 a series of bottom temperatures from Martin Creek to Acme was taken. The temperature of the air at 8 a. m. was $57^{\circ}$; surface of the water at Martin Creek, $55^{\circ}$; bottom at same place at a depth of 15 feet, 580 . This bottom tenperature decreased as we apmroached the lower portion of the river until at $A$ cue, in 30 feet of water, it was $\check{1} 0$.

The fishermen, methods of fishing, etc.-The fishermen on the Sinslaw River are with few exceptions Americans, Norwegians, and Indians. 'The fishing on the main river is done for the most part by the Americans and Norwegians, on the North Fork mostly by Indians. During the past season about three-fourths of the fishermen were permanent residents on the river; the remaining one-fourth rere mostly from the Columbia liver, and in general they restricted their fishing to the lower 8 miles of the river, using drift nets. The resident fishermen are further up the river and set their nets in the ordinary way. Each fisherman regards himself as privileged to fish anywhere along the river he chooses. The fact that a man owns property on the river F. C. 13. $1897-4$ 
is apparently no reason why he shonld restrict his fishery to his own water front or prevent anyone else from fishing there. For convenience each resident sets his nets as near his home as prossible and has usually a number of well-flefined sets. which are sometimes marked. These sets are the places which he regards as the best in which to eatch fish, and are free from snags. One lisherman will seldom intentionally use a set belonging to another.

During the past year very little attention was given to the "Saturday night law." It was said that this has not only been the case in past years on the Siuslaw River, but that it is practically a dead letter on all of the streams in Oregon. The fishermen on the Siuslaw seem to agree that all of them would profit as well by respecting it as by breaking it. A few persist in setting their nets or drifting Saturday nights and, in order that these few men may have no advantage over the others, they, too, put ont their nets on Saturday nights.

According to the law the fishing season closes on the Siuslaw River November 1. This law, of course, is intended for all of the coastal streams in Oregon, and as the time of the run of salmon, especially of silver salmon, varies somewhat in the differ. ent rivers the law does not protect all alike. In the Siuslaw River the largest run of silver salmon nccurs anywhere from (betober st to Torember 10. About this time the first fall rains begin and a gradual rise in the river is accompanied by an increased run of silver salmon. In 1896 the rains began October 24. The river dir not rise much until the night of November 7 , when it rose about 8 fuet, which fut an end to fishing.

The largest run of silver salmon was between October 28 and November 6 . About the same condition of affairs is said to have existed last season.

The law which requires the season to close November 1 in no way protects the chinook salmon, as the run of this fish is over by October 15. As fishing is the chief source of income of mans of the citizens on the Siuslaw River it seems to them ruite a hardship to be obliged to stop fishing during the best portion of the season. All commercial fishing on the river is confined to that portion below tide water; in fact very little is ever done above Mapleton until near the close of the fishing season. The distance from the head of tide to the month of the river is about 28 miles.

Commercial fishing on the Siuslaw is carried on by gill nets, seines, and trolling lines, but mostly by gill nets. The gill nets operated by the fishermen engaged in drifting are from 100 to 150 fathoms long; they are used only on the lower s miles of the river, where the current is too swift during flood and ebb tides to allow them to be set in the ordinary way. There are a great many sunken logs and trees in this portion of the river, as well as further up the stream, and the drifts are therefore usually short. All gill nets used on the river from the head of tide water to within 8 miles of its month are set in the ordinary way. They are all anchored by heavy rocks tied to the lead line at distances of from 3 to $s$ fathoms apart. They vary in length from about 25 to 100 fathoms.

That portion of the river in which gill nets are set varies from about 8 to 150 fathoms in width. The gill nets also vary in length and, as no fisherman confines his tishing to any one portion of the river, very little attention is paid to the latw which prohiloits the use of gill nets reaching more than one-third distance across the river. Nets set in the siuslati liver reach all the way frou one fourth to the entire distance across it. During flood and ebb tide the current in the river is so swift that nets extending from about one-third to tro-thirds across the river have their cork line dragged solow that the net presents a comparatively small and a very poor fishing 
surface. If the net extends from bank to bank the current raises the leat line between anchor rocks and drags down the cork line to the extent of destroying a good share of the fishing capacity of the net. It is quite evident that nets set in the Siuslaw River fish very little except during slack water.

During the new and full mon tides the current in the river is so swift that the outer ends of the nets, which reach only a part was across the river, are drifted torard the shore, and they frequently become so much suagged in drifting one way that it is inpossible to pick them up until the return tide. The fishermen arifting always take advantage of slack water, in order to fisl their nets a longer time withont taking them up. In the latter part of the fishing season many nets nsed in drifting are cut into shorter lengths and set farther up the rirer. It seems to be a fact recognized by the fishermen that in any one portion of the river a net will fish much better at one bank than at the other, so it is much more advantageous to have two nets, each reaching halfway across the river, than one single net reaching entirely across. Three

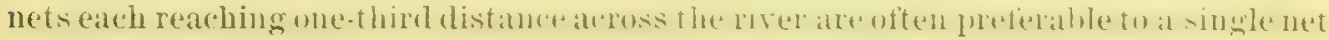
reaching the entire distance. Nets are seldom set in the river in the daytime.

Gill nets are also used in surf tishing late in the fishing season, when comparatively few salmon are entering the river. The usual depth of the net used in surf fishing is about half that used in drifting. At either end of the nets, which are about $\mathbf{1 5 0}$ fathoms long, loug ropes are attached. The net is stretehed along the shore and allowed to be caught by the surf, which carries it some distance to sea; it is then slowly drawn to shore after the manner of a seine. This method of fishing is so difficult and the results so small that it is not much followed.

A short distance above Acme is an excellent seining-ground, but the use of a seine has usually been opposed by fishermen using gill nets farther up the river. The seine was used this season from September 10 to November 1 by those who most strongly opposed it last year, but was less profitable than was expected. The majority of the fishermen wonld faror a law restricting the fishing to the use of gill nets. The seine was but little disturbed this year. One night a boat filled with rocks was sumk on the ground, but this the seine bronght ashore at its first lual next morning. At another time a peculiar framework was anchored in the river, which was so constructerl as to raise the lead line when the seine was about half hanled in. 'This contrivance was also brought ishore. The fact that the seine did not meet with the success expected lessened the opposition to its use. Chinooks were caught by it for the latchery, and this was no doubt a factor in its faror.

Chinooks and the silver salmon are often canght by trolling in the Siuslaw River, and they occasionally take hooks baited with salmon eggs or other bait. On October $10 \mathrm{Mr}$. L. L. bean caught 3 chinooks and 6 silver salmon trolling for about an hour near the month of Martin Creek. The following day S silver salmon were caught by trolling from Mapleton to Point Terrace, a distance of about 6 miles. Some of the chinooks and silver' salmon caught in this way were red in color aud the jars distorted. Considerable trolling is done during October between Mapleton and Point Terrace, not only for sport, but for market as well. The amount of fishing dowe on the Siuslaw liver is rated by boats, each boat having ordinarily 2 men and abont 100 fathoms of net. This past year there were from 75 to 80 boats eugaged in fishing on both the Siuslaw River and North Fork, using a total of abont 10,000 fathoms of net. The seine was operated by 6 men aud 1 horse, and was equivalent to 3 or 4 boats. 
The legal fishing season extends from September 1 to November 1. Some of the fishermen begin fishing as soon as the law permits, but the majority do not commence nutil the cannery begius operations. Tests made in August and early in September showed that the chinook salmon dial not arrive in considerable numbers nutil about the 10th of September. They began to enter the river in the early part of August. Very fer were caught in the lower part of the river after the midale of October. In the vicinity of Mapleton, however, a good many were taken as late as the last of October. They moved up the river apparently very slowly, evidently remaining for a considerable time in the deeper portions of the river.

At Point Terrace the water is 50 feet deep; near the month of Martin Creek the water is from 25 to 36 feet in depth. A large number of chiwooks remain in these places (or are thought to, at least) until they become red and distorted. 'Lhey seem to be very inactive. Gill nets set near these places catch very few. Hishermen say that as soon as the first full rains come and the water in the river freshens up a little the fish become very active and are easily caught in large numbers. No special effort is erer male to catch the chinooks from l'oint Terrace to head of tide after about the 10 th of October. Many of those taken after this date are so white-meated that they are worth uot over 5 cents each, aud they are usnally thrown overboard by the fishermen. Some fishermen think that many chinools spawn on the margins of these deeper holes, but there is no positive evidence of this further than that late in the fishing season a fer ripe females are caught near or in these deep holes.

October 28 and 29 , just after the first important fall rains, about 50 chinooks were caught near Mapleton, which was the largest catch at this place during the season. $\Delta$ few of these were ripe and others nearly so. These fish were evidently just learing the leep hole near the month of Martin Creek about three quarters of a mile below Mapleton. The larger portion of this catch was rejected by the cannery.

'The fall rains not only increase the amount of water in the river and freshen the lower portion of the stream, but they also lower the temperature of the water. These are donbtless the main factors causing the salmon to leave the deep holes and resume their rum upstream.

Salmon ordinarily reach their spawning-grounds before they are ripe, but there is considerable evidence that they sometimes do not enter the river until almost ripe. Mr. Iseonard Christianson did considerable surt tishing in Norember, 1895, and informed us that he canght a few ripe chinooks then. Ėgs were forced from them while the fish were dying on the shore. This, however, is probably unusual.

The North Fork being a much smaller stream than the main river and comparatively few white men fishing on it, it seemed that it was of very little importance as a fishing stream. Late in Oetober it was learued that many chinooks were spawning all along the stream above tide water. On October 23 and 24 the North Fork was examined for some distance both above and below Minerva. 'The water was so stained that salmon could be seen only in shallow water on the gravel bars. These when frightened by our approach at once disappeared in deep water. A few were much mutilated and in a dying condition; in fict, all seen were more or less mutilated. North Fork, though not a large stream, has from tide water to a distance of about 8 miles above a number of excellent spawning-beds, and all showed much evidence of having been so used this year. On the 26th of October about 16 chinooks were caught, all spent lish and all more or less mutilated. As these spawning-beds are only about 8 to 16 
miles from the sea, the mutilations exhibited conld not have been incurred while on their way from the sea, but were received on the spawning-beils. Several dead ones were seen, and many others were so weak and injured that recovery was not believed possible.

On October 23 and 24 at least 50 chinooks were seen on spawning-beds. On all of these the fins were considerably frayer, while most of them were badly mutilated and covered with fungus. A few were so far gone that we captured them by wading in the water and catching them by the tails.

The seals collect in large numbers during the salmon run ou the bar at the month of Siuslaw River. Some enter the river aud are seen nearly lalf way to Mapleton. They are regarded as being destructive to the tishing interests, both by destroying large numbers of fishes and preventing many more from entering the river. These seals are regarded by the fishermen as by far the rorst enemy of the salmon.

The run of silver salmon began later. The first examples were taken about September 10 , but they did not anpear in any considerable numbers until about a week later. From that date they continued pretty evenly until the soth of October, after which they appeared in much larger numbers. They were still abuudant on November 7 , when a sudden rise in the river washed away many of the nets aud practically put a stop to all fishing for the season.

The importance of the salmon fishery of the Siuslaw liiver for each year since its beginning in 1889 is shown in the table which follows. For convenience of reference the salmon taken in Tsiltcoos (Ten-mile) Creek are includer.

\begin{tabular}{|c|c|c|c|c|c|}
\hline \multirow{2}{*}{ Year. } & \multicolumn{2}{|c|}{ Siuslaw IRirer. } & \multicolumn{2}{|c|}{ Forth Fork. } & \multirow{2}{*}{$\begin{array}{l}\text { Tsiltcons } \\
\text { Creek- } \\
\text { silver. }\end{array}$} \\
\hline & Chinook. & Silver. & Clinook. & Silver. & \\
\hline 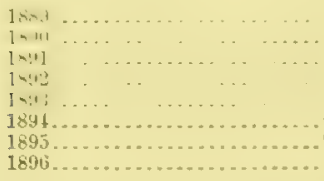 & $\begin{array}{r}9,1100 \\
6,500 \\
16,500 \\
7,000 \\
4,000 \\
1,300 \\
4,2100 \\
4,378\end{array}$ & $\begin{array}{l}62,340 \\
+1,320 \\
23,450 \\
86,340 \\
78,430 \\
81,642 \\
69,454 \\
57,000\end{array}$ & $\begin{array}{l}4,000 \\
2,340 \\
6,800 \\
3,050 \\
1,100 \\
1,234 \\
1,600 \\
2,100\end{array}$ & $\begin{array}{r}16,432 \\
9,3 * 0 \\
2,100 \\
13,460 \\
13,000 \\
6,742 \\
4,340 \\
4,650\end{array}$ & $\begin{array}{l}8,000 \\
(a) \\
(a) \\
(a) \\
8,340 \\
4,870 \\
8,200 \\
1,578\end{array}$ \\
\hline Totals ............... & 52,878 & 502,973 & 22,224 & $69,0.44$ & $27,94 \mathrm{~s}$ \\
\hline
\end{tabular}

From this it appears that the total number of chinook salmon from the Siuslaw River and the North Fork handled by the canneries in the eight years was 75,102 fish, or $1,301,632$ pounds. Mr. Kyle estimates that this amount should be increased by one-sixth, to cover the number salted or shipped away. This would give 87,619 fish, or $1,518,750$ pounds. The total number of silver salmon haulled during the same period was 599,965 fish, or 5,429,675 pounds; increased by one-sixth for tish salted or otherwise utilized, the total becomes 699,959 fish, or $6,33 \pm, 620$ pounds. 'The mumber of silver salmon taken in the outlet of Tahkenitch Lake (Five-mile Creek) is said to have averaged about 5,000 fish per year for the last three years.

Condition of salmon.-The chinooks canght in the Siuslaw River are not so fat as those caught in the Columbia. This is no doubt due to the fact that the Siuslaw has only a fall run. In any river the spring run is always better than the fall run; the 
early spring run is better than the late spring run, and the early fall better than the late fall run. The condition of the salmon depends on the length of time he remains in fresh water before sparning. Those whose sexual organs are the least developed have redier :ud fatter flesh, and these are the ones which must remain in fresh water the longest time before sparning.

Salmon taling the hook.-Fishermen hold ditterent opinions as to mhy salmon take the hook, some regarding it simply as due to the pugnacious disposition of the fish, others as showing a playful disposition. Both males and females will take the hook. The baited look falling near them or the silvery spoon passing rapidly by no doubt produces an involuntary impulse on the part of the fish to seize it.

The Sinslue hatchery.-This batchery is at Mapleton, Oregon, on the Sinslaw liver, about 26 miles above its mouth, or 1 is miles below the head of tide water. The building is about 300 feet from the river and is supplied with water by gravity from a small spring brook, which flows within 200 feet of the building. This supply is abundant and of good quality. As there was no rack in the river, fish for spawning purposes could be obtained only at the seining-gromnd near Acme, about 16 miles below Mapleton. The method followed mas to retain the fish in live-boxes nutil they were ready to spawn. Special boxes were built lor this purpose, the fish put in them at the seining-gromil, then they were Hoated on the tide up to Mapleton, where they were tied until the fish were utilized.

The first live-box was built September 17. It was made 20 feet long, 10 feet wide, and $4 \frac{1}{3}$ feet deey. The frame-work was made of 3 by 6 material; to this were nailed horizontally 1 by 4 strips, with interspaces of abont 21 inches. The lumber used was undressed. This box will hereafter be referred to as Box No.1. On September 19 Box No. 2 was built, 16 by 5 by 41 feet. This box diftered from No. 1 only in being made out of boards 6 and $S$ inches wide instead of 4 inches, and in having the interspaces narrower. These were not more than 2 inches wide anywhere, and near the top of the sides no interspaces were left, the first two or three being placed against each other. On September 21 Box No. 3 was built, not differing in any way from Box No. 2. On the 1st of October Box No. 4 was built. It was made of dressed lumber and was 20 by 6.1 by 4.1 feet. Care was taken to have this box as smooth iuside as pos. sible, so that the fish might not become injured in any way on account of contact with the box.

The account of the experiments with each of these boxes is given with considerable detail, in order that the nature of the work and the couditions under which it was done may be fully understood. On September 18,43 chinook salmon were placed in Box No. 1. They were obtained from the seines and carried in sacks a few feet to a small live-box, in which they were floated to No. 1. The next day 48 more salmon were jlaced in this box. On september 21,47 salmon were placed in No. 2 , and the next day 22 fish rere put into No. 3 , to which 6 more were added on the morning of the 23d. These three boxes, with 91,47 , and 28 fish, respectively, were lashed together and were started drifting up the river with the tide. 'This tide carried them upstream abont 73 miles, or about $\frac{1}{4}$ mile below MeLeod's whart. Here the boxes were taken in tow by the steamer Lillian and brought to MicLeod's wharf. The next day they were drifted to Point Terrace, a distance of abont 51 miles, and on the following uight they were drifted 21 miles farther to Hartley's wharf. The nert day, the 25th, they were drifted 13 miles farther, which brought them within mile of Mapleton. They were 
tied up here until the 27 th, when the Lillian took them in tow and brought them to the Mapleton wharf, where they were kept until the fish were spawned.

Three fish were placed in Box No. 4 on the evening of Oetober 1, and 29 more were, arded the next morning. This box was set drifting on the evening of October 2. 'The fish were ruite restlexi, jumping and striking against the top of the box in eflorts to get out. After floating abont $1 \frac{1}{2}$ miles this box was tied up for the night. That evening it was covered with spruce boughs, so as to darken it and at the same time to canse it to float lower in the water. The next morning it was drifted to within half a mile of McLeod's wharf, or abont 6 miles. The bor was anchored here until the evening flood tide, when it was drifted to McLeod's wharf and tied up. The next day it

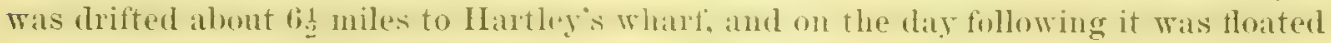
to within half a mile of Mapleton, to which place it was taken on the next tide on the morning of October 6. It was tied in a protected place in the river opposite Mapleton, where it was not subject to the disturbances to which the other three were liable. On October 8 two more salmon, which had been caught in a gill net near by, were placed in this box, thus increasing the number to 34 . Except during the first evening the fish in this bex remained yulet and showed nu signs of restlesisness under the restraint. Boxes 1, 2, and 3 were tied to the piling at the upper end of the wharf at Mapleton. The fish were here occasionally disturbed by persons coming about the boxes or step. ping upou them; whether this really increased the mortality or not can not be certainly stated, but it seems reasonable to believe that it would prove detrimental to the fish.

An unusually low tide on October 15 left Box No. 3 about one-third out of water. This seemed to distress the fish, and may have caused some injury. During the latter part of October about 12 more fish were put in No. 1. These had been caught in the gill nets at IIapleton.

The total number of fish which were experimented with was as follows: In Box No. 1,103 ; in No. 2,47 ; in No. 3,28 ; in No. 4, 34. No accurate record was kept of the number of each sex, but at least three fifths of the total number were females.

The mortality among the fish in these different boxes is shown in the following tabular statement:

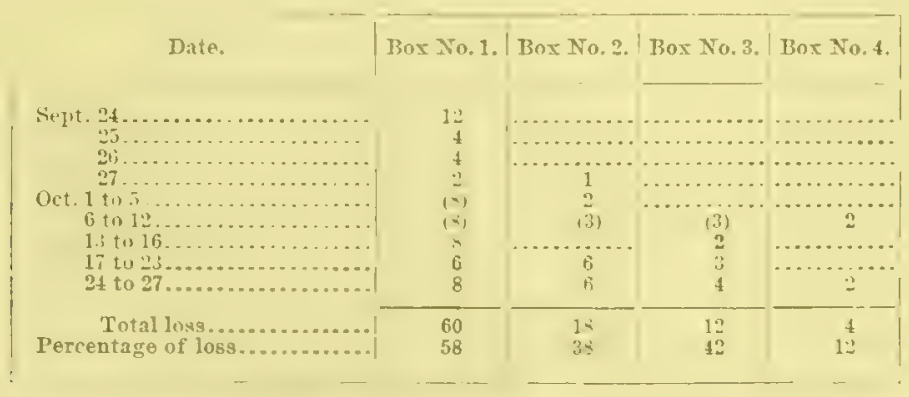

After the taking of spawn began, October 26 , the fish were shifted about from one box to another, and, though a few continued to die, no accurate record was kept. The mortality was greatest in No, 1 and least in No. 4. The crowded condition of the fish in No. 1 was doubtless a feature which contributed to the loss.

After October 26 , when spawn-taking began, the fish were shifted abont from box to box, and it was therefore impossible to keep an accurate record of the number dying 
in each as originally apportioned. The total number that died after October 27, however, was 15 , and on November 15 a sudden rise in the river broke open box No. 1 and 30 fish escaped. The total loss, therefore, was 112 dead and 30 escalyed. The 70 which were lett were spawned. Of this number, 36 were females and 34 males; to this number should be added 8 females and $s$ males taken from the gill nets at Mapleton; these 86 ( 4 females and 42 males) were spamed at different times between October 26 and November 15. The total number of egrg taken is stated by Mr. L. E. Bean to have been 216,000 .

An examination of a great many of the tish which died shomed that some had received internal injuries which probably eansed their death. Others which showed no intermal injuries exhibited severe bruises which doubtless hastened their death.

Particular pains were taken with the fish in Box No. 4. Care was taken in handling them when they were first placed in the box. The box had been constructed with unusual care by making it smooth inside and placing the boards close together, so as to admit but little light, and it was anchored at Mapleton in a sechded place where the fish were subjected to the minimum amount of disturbance. As a result, a higher percentage of success was attained with this box than with the others. With Nos. 1, 2, and 3 the principal factors which rere detrimental were the following:

1. Too many fish were put in each, resulting in too close crowding.

$\because$. The interspaces were too wide, thus letting in too much light and making the fish more restless.

3. The rough surfaces on the inside of these boxes caused injuries to the fish striking against them.

4. Some of the fish were not handled with proper eare when placed in the boxes.

5. Duriug the interval betreen the arrival of these boxes at Mapleton and the spawniug of the fish they were lept in a place where the fish were subjected to some annoyauce.

If the fish in these three boxes had been treated with the same care and attention as was bestowed upon Box $\mathrm{Y}_{0}, t$, it is quite certain that the measure of success would have been greatly increased. Of the 217,000 eggs taken Mr. Beau reports that he hatehed and successfully liberated 180,000 .

Conchsions. - l'hese experiments seem to demonstrate that it is entirely praticable to retain salmon intended for spamning purposes for a period of at least six weeks in properly constructed live-boxes, but'in order to operate Sinslaw hateliery with the best results, particular attention shouk be given to the following details:

1. The boxes should be constructed with as much care as possible. They should be made smooth inside. No interspaces should be left in the torj nor in the uprer third or half of the sides and ends, and those elsewhere shonld not exceed "2 or 3 inches in width. It is also desirable that the boxes be made 6 to $S$ feet deep instead of $4 \frac{1}{2}$ feet.

2. It will prove advantageons to get as large a proportion as possible of the fish desired toward the close of the rum, as they will be more nearly ripe and will not hare to be kept so long in the boxes. It is also believed that these fish are not so restless in the boxes as are those canght earlier in the rum.

3. The fish should be handled carefnlly when plaeing them in the boxes, so that they may not receive any serious bruises.

4. Too many fish should not be placed in any one box. In our julgment each fish should be allowed at least 20 cubio feet of space. 
TSILTCOOS AND WHOAHINK LAKES, OREGON.

The investigation of these lakes was undertaken in response to a petition signed by numerous citizens living in their immediate vieinity and addressed to the United States Commission of Fish and lisheries under date of June 13, 1s96. 'The petitioners asked that Tsilcoos Lake be stocked with black bass and that a plant of brook tront be made in Whoahink Lake. To determine the advisability of complying with these requests, Dr. Meek was directed to make an examination of these lakes, particularly in regard to the following points:

1. Are these waters suitable as to temperature, quality, and food supply for the species requested ?

2. Would the introdnction of these species lave any detrimental effect upon the food or game fishes native to those waters or to waters into which the introduced species might spread?

3. Would the species which it is proposed to introduce probably thrive so well as to afford, after a few years, better fishing than is now furuished by the native species?

Three risits were made by Dr. Meek to these lakes, the first on October 7 and $S$, when only Tsiltcoos Lake was seen; the next October 15 to 19 , during mhich time considerable work was done on each of the lakes; the third trip Norember "2S to December 7 , when the lakes were examined carefully and extensive collections made.

The conclusion reached from a study of the conditions obtaining at these lakes is that it is not advisable for the Commission to stock them with black bass or brook tront. The planting of black bass in Tsiltcoos Lake would prove detrimental to the silver-salmon fishery carried on in the outlet of that lake, and the probability that the bass would in time spread to the Siuslaw and the Umpqua is too great to warrant the risk. As to placing brook trout in Whoahink Lake, it is not believed that that species would ever become so well established as to afford better fishing than the native species supplies. These lakes are already abundantly supplied with a native tront which attains a weight of 2 pounls or more, which possesses excellent game qualities, and whose flesh is firm and sweet. If these trout are properly protected, there is no reason why Whoahink Lake should not become an important fishing-resort.

The detailed report upon these lakes follows:

\section{ISILTCOOS AND OTHEIR LAKFS.}

Between the mouths of the Siuslaw and Umpqua rivers, and almost bordering the sand hills along the shore, are three large lakes and a few small ones. The investigations were restricted to the large lakes: these lie in a line parallel with the ocean beach and comprise at least three-fourths of the distance betweeu the Siuslaw and Umpqua rivers. They are quite peculiar on account of their great irregularity in outline. The amount of shore line as compared with the area of each is very great.

Whoahink Lake, or Clear Lake, as it is more commonly known, is abont 2 miles from the Sinslaw River at Glenada. This lake is very irregular in outline aud deeper than the other two. Except a small portion in the sonthwest cormer, it is surrounded by hills from 20 to about 200 feet in height. The hills immediately surrounding the lake are composed of a soft, irregularly stratified sandstone, and evidently of a much nerrer formation than the higher hills to the sontheast. The inlets are ouly ravines, some of which contain many small springs. The points of land projecting into the 
lake are being yuite rapilly worn away by rough water, forming hlufis. The surface of the lake at one time was somerhat lower than at present; this is evident from the fact that on a shoal place on the east side (near the middle of section 14) stumps of trees are seen some 10 feet below the surface. The former outlet of the lake was into the outlet of Tsiltcoos Lake. A few years ago this outlet became closed by shifting saud, causing the water to rise in the lake at least 6 feet above its present level. A new outlet, a short distance to the east of the old one, was dug to Tsiltcoos Lake some four or five years ago. The new ontlet was not only intended to lower the sur. face of the lake, but to aftiord a water power for a small sawmill. It has never been so used. The material throngh which the ontlet was dug is a fine clay, so compact that it erodes very slowly. In the extreme ends of the arms of the lake are some tules aud small areas of other water-plants.

The surface of Whoahink Lake is about 15 to 20 feet above that of Tsiltcoos Lake, from which it is less than half a mile distant. The timber on the hills bordering the lake was nearly all destroyed by fire some sixty years ago. It is being replaced by a growth of tir, alder. hemlock, maple, rhododentron, hucklebery, and a vigorous growth of ferns. To the west aud bordering the sand hills about half a mile distant from the lake are many bill pines. The shore was everywhere so snaggy that a seine could not be used and our collecting apparatus consisted only of gill nets and trot lines. This lake is reported as having very few fishes in it, and our experience confirms this view. The water is clear, though much less so than in the monntain lakes of Idaho; the depth is usually from 30 to 78 feet. The water is not very cold, as may be seen from the following recorded temperatures:

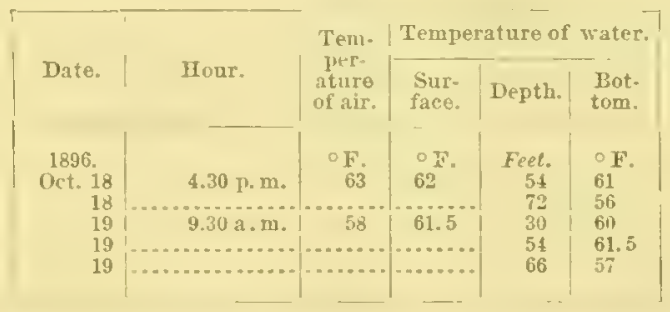

Tsiltcoos lake is larger and more irregular than Whoahink Lake. The main body of the lake is about 2 miles in extent from uorth to south, and 1 to 2 miles from east to west. It is also supplied with several arms, usually about a fourth of a mile wide and from $\frac{1}{2}$ to $1 \frac{1}{2}$ miles long and extending in different directions. Tsiltcoos Lake is comparatively shallow. In summer its greatest depth is about 17 feet, its average depth being from 10 to 14 feet. During the rainy season the water is from 6 to 10 feet deeper. The bottom is a soft, black mul, like that of Whoahink and Tahkeniteh lakes. Except at a fer intervals the shore is bordered by a rich growth of tules. In the shallow portions around the shore the tules extend into the lake ahout a fourth of a mile. There is also considerable swamp vegetation in and about the tules. The surrounding country is quite similar to that around Whoahink. On the east, and at one point on the south, are blutis of a dark. compart sandstone of mucholder formation than the bluffs around Whoahink Lake. There are also two timbered islands in this lake, composed of this older sumdstone; the larger is about half a mile long and about an eighth of a mile wide. 'That portion of the country bordering the lake on the south and sonthwest was not burnt over during the big fire of about sixty years ago. 
Tsiltcoos Lake has two inlets, 6 to 8 miles long, Maple Creek at the northeast and Tsilteoos Creek to the southeast corner of the lake. In summer these are little more than small brooks, but during the rainy season they become much swollen and afford a sparning-ground for many silver salmon, and possibly a few others, which enter the lake. It is said that abont 6 or 7 years ago many more salmon sparned in Maple Creek than at present.

The outlet of Tsiltcoos Lake is quite small, especially so in summer and at low tide. Gill nets are put across the outlet at low tide and are so anchored and staked down that it is quite impossible for silver salmon, except the smaller ones, to pass them.

October 17 a number of soundings and temperatures were taken in Tsiltcoos Lake. The temperature of the air at $10.15 \mathrm{a} . \mathrm{m}$. was $566^{\circ}$; that of the bottom in various parts of the lake, at depths from 7 to 17 feet, varied from 58.50 to $59.5 \circ$.

Tsiltcoos Creek (T'en-mile Creek), the outlet of Tsiltcoos Lake, is about 5 miles long, while the distance from the lake to the ocean in a direct line is about 2 miles. At low tide in summer there is barely water enough in the outlet to that a small flatbottom boat. At high tide the water in the outlet for its entire length is brackish. There is some commercial fishing, though the fishing season is short (this year from October 10 to about November 5). Many silver salmon enter the lake, as is evidenced by the number canght in onr small gill nets. Fishermen report that salmon are often stranded on the beach. About 100 silver salmon, the first catch of the present season, were brought to the cannery on October 13. There is no reliable evidence that blueback salmon are ever found in this lake or its outlet, and only an occasional chinook is found. On Oetober 16 and 17 the bar at the month of this creek at low tide com. pletely closed the outlet. This prevented salmon from entering and noue had been taken since October 13. The fishermen were watching the surf elosely to see if many salmon were near shore. Ordinarily, if the bar is closed and many fishes are seen in the surf, the fishermen resort to surf fishing until after the bar is opened.

Tahkenitch, or Five-mile, Lake is very irregular in outline. Its greatest length from north to south is about $4 \frac{1}{2}$ miles; east to west about the same distance. This lake consists of four large arms whose general directions are rith the four cardinal points. The eastern arm is the longest, the western the shortest, while the other two are about equal in length. The width of these arms varies from about one-eighth to three-quarters of a mile. In the month of the smallest arm is a small timbered island.

Tahkenitch Lake does not lie in the burnt region. The hills surrounding it rise abruptly to a height of usually about 100 feet, and are corered by a dense growth of tall fir trees of about $1 \frac{1}{2}$ to 3 feet in diameter. In the extreme end of the arms and in a few other places along the shore are found tules and other water regetation similar to that in I'siltcoos Lake. The bottom of the lake is a soft, black mud, like that found in the two other lakes. The depth is very uniform, being from 16 to 22 feet.

Five-mile Creek, the ontlet of Tahkenitch Lake, has its origin in the distal end of the western arm, its mpper end being about 1 mile from the ocean. Its total length is about twice this distance. The sand hills extend almost to the lake. The isthmus separating Tahkenitch and Tsiltcoos lakes is rather low and narrow. So far as we conld learn, the commercial fishing on Fire-mile Creek is very similar to that on Ten-mile Creek. The catch has amounted, according to Hon. A. IV. Reed, of Gardiner, to an average of 5,000 silver salmon for each of the past three years. 


\section{UPPER KLAMATH LAKE, OREGON.}

In 1889 the United States Fish Commission planted 400,000 whitefish fry (Coregonus chupeiformis) in the sonthern end of Upper Kiamath Lake, near Klamath Falls. Ample time having elapsed to enable this species to become well established, observations were made by Messrs. Meek aud Alexauder for the purpose of determining the resul $t$ of the plant.

Pelican Bay was reached on the evening of October 31, and work was carried on in the upper part of the lake until Noveuber 7 , when the camp was moved to the lower end of the lake near the ontlet, where the investigations were continued until the 11 th. During the time spent at this lake the weather was unusually stormy, and it was exceedingly difficnlt to carry on the investigations in a manner at all satisfactory. There were only two really good days for work during the entire time.

For the purpose of determining the result of the whitefish plant gill nets of suitable mesh were set in various places in Pelican Bay aud in the lower end of the lake. Collections of native fishes were also made, and as much time as possible was given to the study of the fish-food supply of the lake, which was found to be abundant and rich in species of Entomostraca, insect larve, and other invertebrate life.

The fish life of the lake does not consist of many species, but the individuals of several of the species are very numerous. These will be discussed fully in the list of fishes at the end of this report, but it seems proper to call attention in this connection to the suckers and trout. There are five or six species of suckers in this lake and each of them attains a large size, which reuclers them of great importance to the Indians on the Klamath Reservation. In the spring of the year, during the spawning time of these fish, vast numbers are caught in traps and by hook and line by the Indians and cured for future use.

The trout are also very common and reach a very large size. Trout weighing 8 to 10 pounds are not at all unusual, examples of 10 to 12 pounds are not rare, and occasionally one weighs as much as $\mathbf{1 4}$ pounds. 'Trout can be taken readily with the Hy in the spring and by trolling in the spring aud fall. In Pelican Bay they may be taken by trolling at any time.

The Klamath lakes comprise a series of lakes which extend in a north-and-south direction in southern Oregon aud northern California. They lie just east of the Cascale Mountains, and are about 4,300 leet above sen level. Our investigations were limited to the largest of these lakes, known as Upper Klamath Lake.

This lake is about 25 miles long and about $S$ miles in average wilth. Its northern half extends in a northwest-and-southeast direction, while its southern half is nearly due north and south. It is quite irregular in ontline, having on its western side two large bays, the upper of which forms the northwestern corner of the lake, and is known as l'elicau Bay. About '2 miles west of Pe'ican Bay is a very large spriug which forms a prominent creek emptying into the bay. The first half mile of this creek is about 50 to 100 feet wide and from 2 to 8 feet deep. After this it widens ont into a large estnary, half a mile or more wide and more than a mile long. On the north this estuary is bordered by a hill, at the foot of which the water is as much as 17 feet deep. The rest of this estuary is bordered by a rich growth of tules and swamp grass. Its depth, except at the north end, seliom exceeds 7 feet, while the greater portion is less than 6 feet in depth. There are, especially on the east side of this estuary, many small narrow arms known as sloughs. These sloughs are about as 
deep as the estuary, and each supports a rich growth of Potumogeton, Myriophyllum, and Elodea. 'These water-plants are also more or less abundut along the water's edge just inside the tules, but are scarce in the main body of the estuary. 'The water in Pelican Creek and estuary is very clear, and when it is not ilisturbed the bottom can be plainly seen everywhere. The bottom of the creek and estuary is composed of a light fluffy mud, varying in color from dark grayish to black.

The water in the lake when we saw it was not clear. The fine sediment held in suspension was no doubt picked up from the bottom during rongh weather.

The northern portion of Upper Klamath Lake contains many tule islands, and is evidently very shallow. Its shores north of Bare Island axe very marshy. The main portion of the lake, or its middle half, is bordered on each side by mountains which rise from the water's edge to an altitude of 1,000 to 1,500 feet above the lake. 'Toward its southern end the lake becomes narrow. Its shores are mostly marshy and bordered by tules aud willows. It also contains considerable water vegetation, the same as at its north end. There are two islands in the lake, Bare Island and Buck Island, each about 500 feet high.

North of the upper end of Upper Kiamath Lake is a large area of tule marshes, (6) to 10 miles wide and 10 to 12 miles long. Isying in this marsh is a small lake which has sometimes been inproperly called the Upper Klamath Lake. It is now regarded as being only a part of Upper Klamatl Lake. It is about 2 miles from the main lake aud is about 3 miles wille and 6 miles long. Through this marsh flow several small streams, the principal ones being Seven-mile Creck and Wood River. Williamson River, the prineipal stream flowing into Upper Klamath Lake, is of considerable size and much importance in its relations to the fishes of the lake. About 10 miles above its mouth it receives from the east a large tributary known as Sprague River. About half a mile above its month it is 125 feet wide and 10 feet deep. It flows before entering the lake though a low, Hat, marshy plain covered with tules and swamp grass. On the banks of the river is a rich growth of willows. The current is very moderate. We rowed about 2 miles or more np the river and noticed no important change in it. The water in the river was very dark, evidently stained to some extent by vegetation.

The small lake just below Klamath Falls is abont $\frac{3}{4}$ mile wide and 2 miles long. This lake is surrounded by a rich growth of tules and some willows. The depth about half a mile below Klamath Falls was 15 feet. On Norember 9 the surface temperature was $4211^{\circ}$; bottom temperature in 15 feet of water, 4210 . We set one large and two small gill nets in this lake on Norember 9 and took them up on Norember 11, obtaining 4 chubs (Leueiscus bicolor) and 2 tront.

The ontlet of Upper Klamath Lake is Link River, a short stream not over $1 \frac{1}{4}$ miles loug, consisting of a series of rupids and falls.

Upper Klamath Lake is a rather shallow body of water. The creek and estuary at Pelican Bay are from 2 to 8 feet deep in the npper part and from 6 to 16 feet in the lower portion. A line of soundings was run across the mouth of the estuary and the deptlu was found to be abont $5_{2}^{1}$ feet.

Pelican Bay and the north eud of the lake are very shallow. A line of soundings was ruu from the mouth of the estuary of I'elican Creek to the mouth of Williamson River, and 8 feet was the greatest depth found, while the average was not more than 6. feet. The bottom could be easily seen'anywhere when the surface of the water was smooth. It seemed to be composed of loose, decaying vegetation, into which the 
sounding lead would usually sink several inches. We were unable to take any soundings in the middle of the lake hetween bare and linck islands. While this is doubtless the deepest portion, we were informed that the water even here probably does not exceed 30 or 40 feet in depth. The south end of the lake is a little deeper than the upper portion. The greatest depth was found near the outlet and was 20 feet. The portion south of Buck Island will not average more than 12 or 13 feet deej)

The temperature observations mate at Upper Klamath Lake are given in the table which follows. All the water temperatures except those at the surface were taken at the bottom. Oriug to the shallowness of the lake the temperature of its water is everywhere affected by that of the air.

\begin{tabular}{|c|c|c|c|c|c|}
\hline Date. & Нонт. & Station. & $\left|\begin{array}{c}\text { Ten- } \\
\text { per- } \\
\text { ature of } \\
\text { air. }\end{array}\right|$ & $\mid \begin{array}{c}\text { Depth } \\
\text { of water. }\end{array}$ & $\begin{array}{l}\text { Tem- } \\
\text { per- } \\
\text { ature of } \\
\text { water. }\end{array}$ \\
\hline $\begin{array}{r}\text { Nor. } 2 \\
2 \\
2 \\
2 \\
2 \\
3 \\
3 \\
3 \\
3 \\
3 \\
1 \\
5 \\
5 \\
5 \\
5 \\
5 \\
5 \\
5 \\
5 \\
5 \\
5 \\
5 \\
5 \\
5 \\
5 \\
6 \\
6 \\
9 \\
9 \\
10 \\
10\end{array}$ & 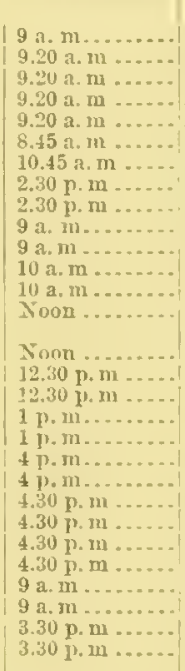 & 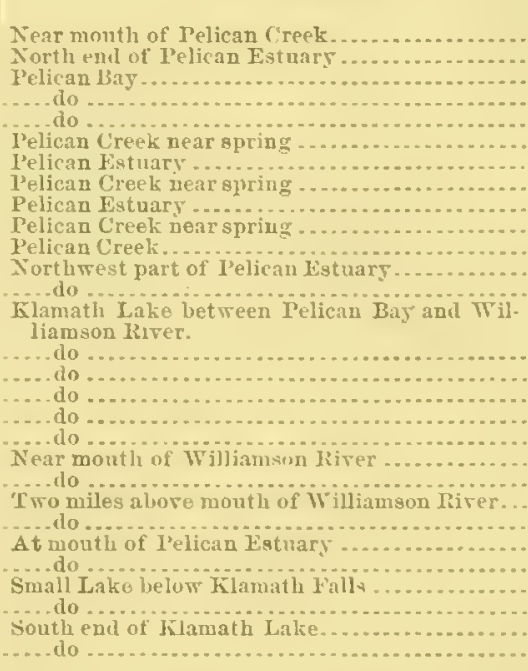 & 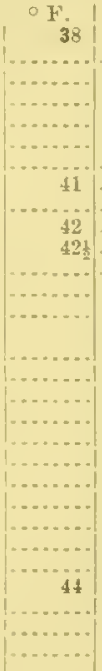 & 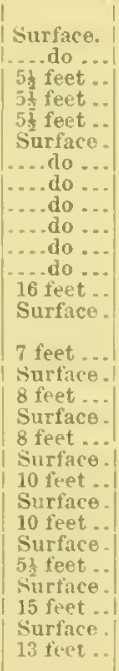 & 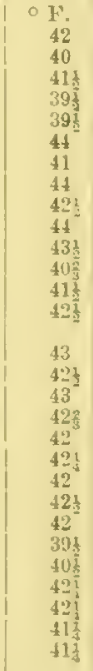 \\
\hline
\end{tabular}

Charcter of bottom.-The large area of tule and marshy lands surroinding the lake has doubtless had much to do in determining the eharacter of the bottom of I pper Klamath Lake. The lake is very shallow, and the vast amounts of decaying vegetation carried into it and the ever-increasing area of tule lands render it more shallow year by year. The bottom, where we examined it, was composed of loose, disintegrating vegetable material, with no sandy or gravelly bottom.

Fishes.-Gill nets of suitable mesh were set in this lake in various places, chiefly in Pelican Bay and in the lower end of the lake. A good many trout and elubs and a few suckers were taken, but no whitefish were caught and none was seen anywhere. Intury anong prople at Klamith Falls and elsewhere about the lake failed to elicit evidence that whitefish have ever been seen there since the plant was made. It is to be regretted that nets could not have been set in the middle portion of the lake, as it is there that lish would be fomd if any have survived. But when it is considered how shallow the lake is, how warm the water probably becomes in summer, aud

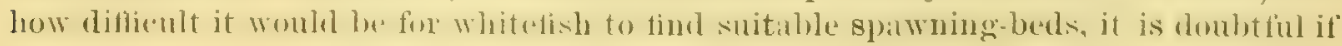
the eastern whitefish would thrive in such a lake. 
Advantages of a trout-cultural station at Klamath Falls.-The trout of Upper Klamath Lake are probably not surpassed by any lake-dwelling trout in America in beanty, size, gaminess, or sweetuess and delicacy of flavor. They are excellent tront to propagate and plant in otlier lakes. Trout-cultural operations could be carried on at some point on Upper Klamath Lake rery advantagenusly. P'erhaps the best location would be at Klamath Falls, where all the engineering conditions are excellent. Fish can be obtained readily and in abundance at any time. A station located upon this lake would be useful in maintaining the supply of trout in it and neighboring lakes and for furnishing fish for planting elserlhere in suitable lakes. 'The distance of' Flamath Falls from the railroad is the chief objection to the establishment of a station at that place.

\section{CRATER LAKE, OREGON.}

In the spring of 1896 the U. S. Commissioner of Fish and Fisheries received a request to plant trout in Crater Lake, Oregon. This request was made by citizens of Medtord, Ashland, and Klamath Falls, aud by the Mazamas, a club of mountain climbers with headquarters at Portland, whose members take an active and intelligent interest in discovering and making known the scenic and other natural attractions of the Northwestern States. Before complying with the request, the Commissioner decided to have made such investigations as would determine whether the physical and biologie conditions existing at Crater Lake are such as will permit fish to thrive in it. These investigations were male hy l'rofessor Evermann and Prof. U. O. Cox, of Mankato, Minnesota.

Crater Lake is abont $\mathbf{1 0 0}$ miles from the nearest railroad station, and is reached by a wagon road, which has a number of steep, rough grades. The Mazamas had selected this lake as the place of their annual meeting for 1896, and the Fish Commission party by their invitation made the trip to the lake with them, thus obviating the necessity of employing special conveyances aud making the trip comparatively inexpensive. The party left Ashland by wagon August 13 and reached the lake on the morning of August 19. Work was carried on at the lake until Angust 24, when the party set out upon the return trip to Ashland, which was reached August 26.

Crater Lake* lies in the top of Mount Mazama and on the very summit of the Casciule Range, about midway between Mount shastal and Munt Hool. Its latitude. is $42^{\circ} 56^{\prime} \mathrm{N}$. and its longitude is $122^{\circ} 7^{\prime} \mathrm{W}$. In mauy respects it is one of the most interesting uatural wouders in America. It is approximately circular aud averages a little more than 5 miles in diameter. It is completely encircled by a bold escarpment ranging from 500 to 2,000 feet in height above the surface of the water. Although the steep slopes of the escarpment are in some blaces whll womled, they are generally either cliffs or talus, desending to the lake and plunging into deep water. There are many places where the walls are almost perpendienlar, and at only two or three places is it possible to descend to the water's edge. The lake has practically no shores or beaches; only in a few places is there sufficient beach to aftord standing room. The average diameter of this great pit at the top is 5.7 miles and its depth is 4,000 feet. The highest part of the wall surrounding this lake is s.'. the surface of the lake is 6,239 feet above the sea.

* In our general descrintion of this lake we hare made free use of the excellent account given by Mr. J. S. Diller, of the U. S. Geological Survey. Mr. Diller has made a careful topographic survey of the region and possesses a thorongh and intimate acquaintance with Crater Lako. 
The rim of the basin now occupied by Crater Lake is the present summit of what was once a monntain cone. That this is simply the frustum of what was once a complete mountain cone is evidenced by the attitude of the sheets of lava aud ejected volennic material which form the rim. They all incline away from the lake, indicating a common sonrce from a crater that surmounted a huge voleano high in air above the place now occupied by the lake. At that time, of course, neither basin nor lake existed. Mr. Diller thinks that this great volcanic mountain, recently named Monnt Mazama, must have extended about 5,000 feet higher than the remaining fragment, thus unaking its height about 14,000 feet, nearly that of Mount Shasta. What became of the top of Xlonut Mazama is an interesting question. The geologists are convinced that at some period in its history the molten interior, instead of escaping through the crater in the usual way, found an outlet at a lower level. The top of the mountain being thus left a mere shell and without adequate support, fell in and became engulfed in the vast pit which the lake now partly fills. The pumice upon the surface for many miles around Crater Lake was probably blown out by the volcano before the pit dereloped, and the volcano of Wizard Island was actire at a much later stage upon the bottom of the pit. It was the scene of the last ermption about the lake, and, although recent in appearance, must have occurred centuries ago.

Crater Lake is, so far as known, the deepest lake in America. Many soundings have been taken by the United States Geological Survey. Over only very limited areas was a depth of less than 1,000 feet found, while over a large part of the lake the depth ranges from 1,800 to 2,000 feet. In the eastern portion of the lake is a great level floor, with a nearly uniform depth of "2,000 feet for a distance of more than 3 miles. In the restern part are three or more small cones, one reaching within 93 feet of the surface of the water, while another rises $S+5$ feet above the water. 'This is Wizard Island, a perfect cinder cone, with symmetrical slopes, and in its top a erater 80 feet (leel\%. This cone is composed chietly of red lapilli, and so new and fiesh that it is sparsely forested and shows no trace of meathering. Abont the base of this island cone is a rough fringe of lava, which has spread in all directions to far beneath the water's level. The shallowest parts of the lake lie rest and south of Wizard Island. The average depth in this area probably does not exceed 150 feet.

Crater Lake has neither iulet nor visible ontlet. The catchment area is scarcely greater than the lake itself. During the summer season several streams triekle down the walls from the snow banks which lie within the rim; these streans are all very small, but a few of them continue throughout the summer, as some of the siow banks lying on the sonthern walls never entirely disappear. The amount of precipitation is believed to be greater than the evaporation, but the level of the lake does not appear to be rising. It is therefore quite probable that there is a subtermeau outlet, aud the large springs in the vicinity of Fort Klamath may have their source in Crater Lake.

The water of Crater Lake is cold, fairly pure, and exceedingly clear. Though suflicieutly pure for all tish-cultural purposes, it is slightly flat to the taste and doubtless contains some minerals in solution. Froth or foam readily forms when the water is disturbed. The elearness is remarkble, an ordinary dinner plate being distinctly visible at a depth of nearly 100 feet, even in a hazy atmosphere.

The color of the lake is a wonderful blue, except in certain comparatively shallow places near the shore. In the deeper parts of the lake it is the most intense blue we have ever seen; from there toward the shore, and in the changing light and shatows of 
cliff's and elouds, the color's change from ultramarine through cobalt and azure blue to smalt blue and hyacinth, and even to royal purple; violet, and mauve. So marvelously and strangely beautiful are these colors that one never tires watching and studying them. The general effect as one views the lake from some advantageous point upon the rim is profoumdly impressire. Two thousand feet below lies the lake in whose placid blue waters ererything is so perfectly mirrored that one can not tell where the real ends and the mirror begins. Near the mest shore rises Wizard Island, symmetrical and beautiful in all its proportions, while around the lake is a circle of 20 miles of nearly perpendicular wall, hundreds of feet high and unrivaled in its scenic effects.

Temperatures.-Considerable time was devoted to the making of temperature observations in different parts of the lake and at different depths.

The following table gives the surface temperatures recorded:

\begin{tabular}{|c|c|c|c|}
\hline \multirow[b]{2}{*}{ Date. } & \multirow[b]{2}{*}{ Hour. } & \\
\hline & & station. & $\begin{array}{l}\text { Temper. } \\
\text { ature. }\end{array}$ \\
\hline $\begin{array}{r}1896 . \\
\text { Aug. } 19 \\
20 \\
20 \\
20 \\
20 \\
21 \\
22 \\
22 \\
22 \\
22\end{array}$ & 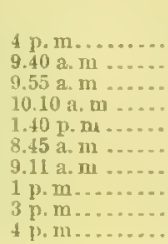 & 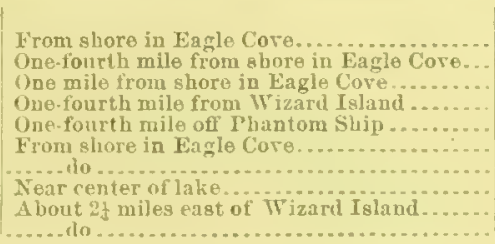 & $\begin{array}{l}\text { F. } \\
59 \\
57 \\
56.5 \\
58 \\
60 \\
55.6 \\
56 \\
62 \\
61 \\
61\end{array}$ \\
\hline
\end{tabular}

The following intermediate and bottom temperatures were taken, with a NegrettiZambra (leep-sea thermometer tripped by means of a propeller, such as is used by the Albatross in her deep-sea temperature work:

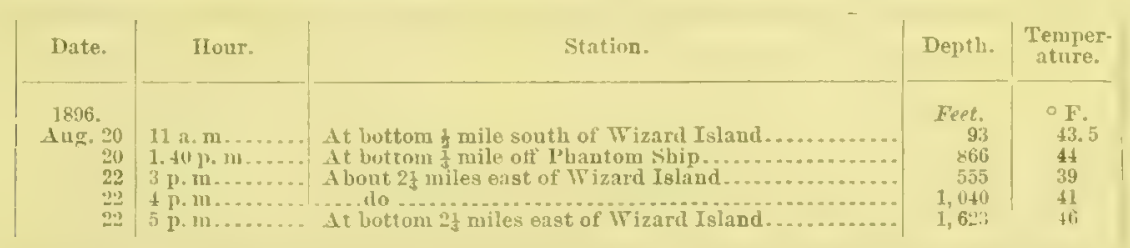

The vertical series taken on August 22 , at a station about $2 \frac{1}{4}$ miles east from the southeast corner of Wizard Island, proved of very great interest. The surface temperature was $61^{\circ}$; at 555 feet it was $39^{\circ}$; at 1,040 feet $41^{\circ}$; and at 1,623 feet, which was at the bottom, $46^{\circ}$. In all other American lakes, so far as known, the coldest water in summer is always at the bottom. The effect of the sun in heating the water of lakes does not ordinarily reach to any great depth. Observations recently made upon Lake Champlain by Prof. George C. Whipple and our own observations made in 1896 upon Alturas and Wallowa lakes showed that the sun's heat did not much affect the temperature of the water beyond a depth of 100 feet.

If there be no error in the above observations, it seems that the waters of Crater Lake are still receiving heat from the rock npon which they rest. The heat of the old voleano has not entirely disappeared. The coldest water is neither at the surface nor at the bottom, but at some intermediate depth. The results of these observations are so unexpected, and the indicated conditions are so unusual, that the matter shonld receive further attention. The only possible source of error which has yet suggested 
itself is that the propeller may not always have workel properly. It is possible (though improbable) that in some cases, when beginning to haul np the thermometer the propeller failed to reverse until some moments iater, in which case the temperature reading would he for some depth other than the one desired. 'The observations should be carefully repeated before the conclusions suggested are accepted.

During the trip of the Mazama party from Ashland to Crater Lake and return a good many temperature observations were made. All of these possess a certain value and it has been thought proper to record them in this connection. The air temperatures were all in the shade unless otherwise stated. The instrument used was a Wilder protected thermometer.

Miscellaneous temperatures recorded on the Crater Lake trip, August 13 to $26,1596$.

\begin{tabular}{|c|c|c|c|c|c|c|c|c|c|}
\hline Date. & Hour. & Station. & Air. & Water. & Date. & IIour. & Station. & Air. & Water. \\
\hline $\begin{array}{l}14 \\
14 \\
15 \\
15 \\
15 \\
16 \\
16 \\
16 \\
17 \\
17 \\
17 \\
17 \\
17 \\
17 \\
17 \\
17 \\
17\end{array}$ & 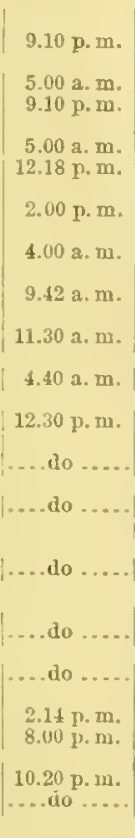 & 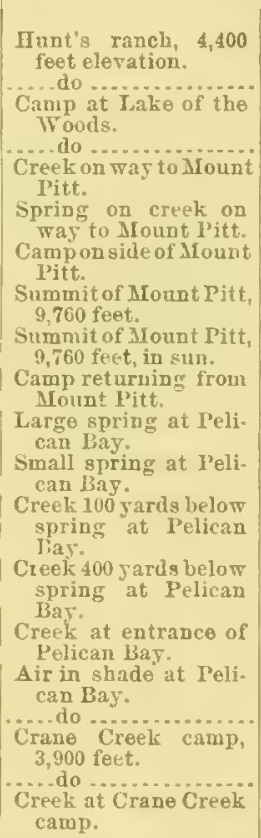 & $\begin{array}{l}77 \\
80 \\
52 \\
44\end{array}$ & $\begin{array}{l}43 \\
43.5 \\
44.75 \\
45.5 \\
47\end{array}$ & $\begin{array}{l}19 \\
19 \\
19 \\
19 \\
20 \\
20 \\
20 \\
21 \\
21 \\
21 \\
21 \\
21 \\
22 \\
22 \\
22 \\
23 \\
23\end{array}$ & 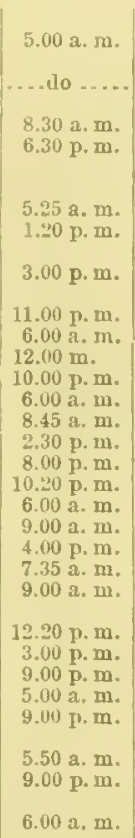 & 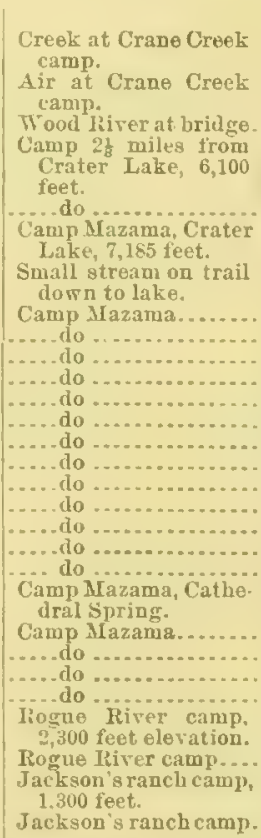 & \begin{tabular}{|l|}
56 \\
54 \\
67.5 \\
52 \\
51 \\
58 \\
61 \\
58.5 \\
55 \\
52 \\
66 \\
59 \\
65 \\
66 \\
69.5 \\
70.5 \\
59 \\
62 \\
61 \\
46 \\
65 \\
57
\end{tabular} & 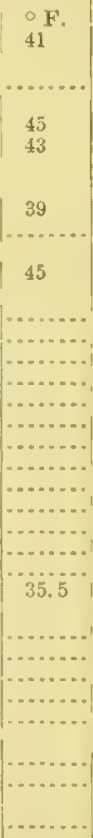 \\
\hline
\end{tabular}

Life of Crater Lalie.-Crater Lake contains no fishes; lakes without inlets or outlets seldom or never do, for fishes uaturally get into one body of water only by swimming to it from some other body of water with which it is connected. Fishes never appear de novo in any lake or stream; if they appear there at all it is because they can swim there from some other lake or stream. Breaks in water continuity, or even considerable falls, are absolute harier's beyond which tishes 'an not go. So with Crater Lake; it has never had any inlet or visible outlet connecting it with any other body of water in which fishes are found aud through which fishes might reach it.

Mammals and birds excepted, only 3 species of vertebrates were found within the rim of Crater Lake, viz, a suake, a frog, and a salamauder.

The snake is the small-headed striped suake, Thamnophis leptocephalus (Baird \& Girard). Two specimens were obtained on Wizard Island. It was not seen elsewhere. 
One frog, hana aurora Baird \& Girard, was also obtained on Wizard Island. Others were seen about the spring below the camp. The salamander is Amblystoma macrodactylum Baird. It is by far the most abundant and most interesting vertebrate occurring at Crater Lake. Our first specimens mere found on the shore under Redcloud Cliffs, where wo found it to be exceedingly abundant. It was afterwards found in considerable numbers along the shore in Lagle Cove and a few were obtained abont Wizard Island. More than a hundred specimens were collected aud many more could have been obtained. The majority of the individuals seen were adults, only 4 or 5 still retaining the external gills were seen. These salamanders were found under the rocks just above the edge of the water of the lake. Sometimes as many as a dozen or fifteen were found under a single tlat stone. These three species are not uncommon throughout westeru Oregon and Washington.

Invertebrate life was found to be fuirly abundant, and a few plants were found. By using fue-meshed surface towing nets cousiderable collections were made. The following is a list of the species obtained:

Algat :

\section{PLANTS.}

Tostoe sp.? Colonies common.

Melosira granulata. Not common.

Pleurosigma sp.? Several specimens.

Surirella sp. Not common.

\section{AXIMALS.}

Crustacea:

Cyclops albidus. Not common.

Cyclojs serrulatus. Not common.

Daphnia pulex pulicaria. Very abunlant.

Insecta:

dilorchestes dentata. Not common.

Chironomus sp. Larvie. Very common.

Ephemerid larvo. Common.

Limnophilus or cacldis fly. Tery alundant.

ANIMALS-C'ontinued.

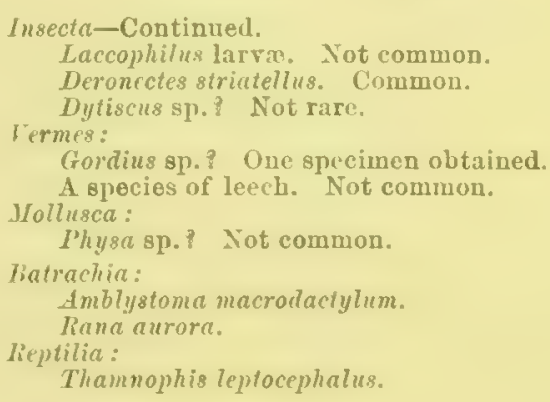

These crustaceans and insect larve are all excellent food for trout, and were found in considerable abuudance, particularly in Eagle Cove. The small entomostracan, Daphnia pulex pulicaria, was the most abundant species, and large numbers could be seen during favorable afternoons swimming at the surface in Lagle Cove. The three other species of crustaceans seemed far less abundant.

Caddis-tly cases were rery abundant on the under sides of rocks lying in the edge of the water. A small black leech was quite common on the rocks in Eagle Cove and about Wizard Island. The small gastropod (Physa) was found about Wizard Island in limited numbers, a species of water-beetle (Dytiscus) was pretty common, and a single specimen of Gordius, or hair suake, was found near the sluore of the island.

There are no water-plants of any size in the lake. On the rocks about Wizard Island the gelatinous masses of colonies of Noston were common. A number of specimens of the diatom, Pleurosigma, were obtained in the towing net, and a few specimens of two other algre were secured.

Summing up the matter, it may be said that while the conditions at Crater Lake are not the most favorable to fish-life, there seems to be no reason mhy trout in limited numbers might not thrive in it. The water is all that could be desired as to purity and temperature, but the depth is so uniformly great that only small areas of bottom suitable for sparning beds are found. The entire absence of all other fish-life and the 
very limited regetation supported hy the lake renluce the food suphly almost wholly to small free-swimming crustaceaus and insect larre. Both are present in considerable abundance, but probaloly not in sufficient quantities to support a large number of fishes. On the other hand, fishes planted in this halie will have no rapacions fishes with which tu contend; the struggle will, therefore, be wholly with the physical environment and the food supply. It has, therefore, been recommended that a plant of trout be made in Crater Lake, and it is hoped that the Mazamas who visit the lake hereafter may make observatious to determine the result of the experiment. The best species to plant is the black-speckled trout of Lake Tahoe, Sulmo mykiss hensharci.

\section{LIST OF FISHES.}

In the following list of fishes we give only those species of which specimens were obtained by us during the iuvestigations of 1 sish. In the nomenclature and sequeuce of species we follow Jordan \& Evermann's Check-List,* recently published:

\section{Entosphenus tridentatus (Gairdner). Three-loothed Tamprey.}

A specimen, 18 inches long, was obtained July 23 in Alturas Inlet, 1 mile abore the lake, and several larvie were dug out of the sand at the head of the lake July 25. Comparing the largespecimen with one 24 inches long, obtained hy Mr. Williams at Bigg Payette Lake, some important differences are noted. In the Payette example the clorsal fins are separated by a space equal to one-thircl the length of the base of the anterior fin, while the Alturas example has the dorsals scarcely separated. The tius are also much higher in this specimen, the height of the anterior dorsal being containcd $3 \frac{1}{1}$ times in head, measured to first gill-opening, or $1 \frac{3}{5}$ times in the height of the second. The infraoral lamina has 5 cusps; the supraoral has 3 , the middle one being much smaller than the other two; the buccal tecth before the mouth are unicuspid; on each side of the oral opening are 4 teeth, the anterior and posterior ones of which are bicuspicl, while the other two are tricuspid. The arrangement of the teeth does not difter materially from that in the Payette specimen. The larva range from $1 \frac{8}{4}$ to $3 \frac{1}{2}$ inches in total length. In all of these the clorsal fin is continnous, though deeply incised.

An example 10 inches long was found attached to a chub in Upper Kilamath Lake, November 10.

2. Acipenser medirostris Ayres. Green Sturgeon.

Common near the mouth of Siuslaw River; sereral taken in a seine near Acme in September, measuring about 18 inches each in total length. At Gardiner, near the mouth of the Umpqua, a good many large sturgeon, probably A. transmontanus, were taken in November and December.

3. Pantosteus jordani Erermann. Western Ijtnch Suctier.

During the season's work this sucker was found only in Wallowa Lake, Oregron. Two small specimens were obtained in the upper end of the lake August 24.

4. Catostomus tsiltcoosensis, new species.

Type No. 48179, U. S. Nat. Mns.; cotypes No.38, U. S. F. C., and No. 5703, L. S. Jr. Univ. Mus.

Type locality: Tsiltcoos Lake, Lane County, Oregon, where numerous specimeus were obtained December 2, 1896, by Dr. Meek.

Apparently most closely related to Coccidentalis Ajres.

Head $4 \frac{1}{2}$; iepth 5 ; eje $6 \frac{1}{2}$ in head; snout $2 ;$ D. $13 ;$ A. 7 ; scales $13-65-8$, 31 before the dorsal. Pectoral $1 \frac{1}{6}$ in head; Iongest dorsal ray $1 \frac{1}{3}$; base of dorsal $1 \frac{1}{2}$; longest anal ray $1 \frac{1}{4}$; ventral $1 \frac{3}{5}$. IBody rather slender, subterete; head small, snout long and pointed; mouth inferior, overhung by the pro. jecting snout; lips rather thin, one row of large papille on upper lip, aud about 2 irregular rows of smaller ones behind or inside of it; lower lip incised nearly to base, 1 or 2 rows of small papilla across the isthnus; lobes of lower lip moderately long and thin, the bases with papillie merging into plications tomarl the tips. Eye quite swall, the anterior edge of orbit at middle of head. Top of head flat or very slightly convex between tho ejes. Fins small; pectorals short and rounded;

A check-List of the Fishes and Fish-like Vertehrates of North and Middlo Ameruca, in Report U. S. F. C. for 1895 (Decomber 28, 1896), 207-590. 
ventrals short, rounded, the midule rays but little longer than the others; anal small, somewhat pointed; margin of dorsil slightly concavo; caudal lunate, not deeply forked. Muciferons canals on heal not strongly developed. Scales moderately large; lateral line nearly straight, not running upward toward nape.

Length of type, 8 inches to base of eandal.

The cotypes ayrue closely with the type in all characters of importance.

We have compared our specimens of this species with specimens of $C$. occidentalis (Fig. 2) from tho Sacramento River and lind important lifferences. Compariog examples of the same size, we fiud. that $C$. tsiltcoosensis has a smaller head, longer, wore pointed suout, smaller eje, larger scales, and much smaller fins; the pectorals in $C$. occidentalis aro falcate while in this species they are more rounded, and the ventrals also are less pointed.

An example of $C$. occidentalis 9 inches long has the head 4 ; depth 5 ; eye 5 ; ; snout $2 \frac{1}{2} ; \mathbf{1}$. $12 ; \mathbf{A} .7$; scales 13-70-10, 41 liefore the dorsal.

This species is afundant in Toiltcoos Lake and Siuslaw River. The spocimens from Siuslaw River were obtained in brackish water.

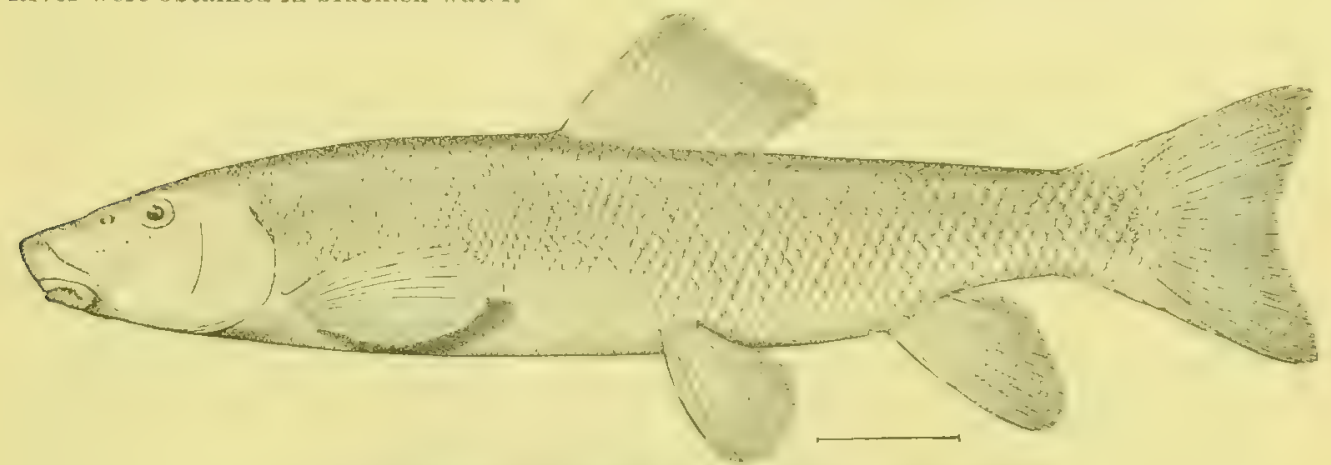

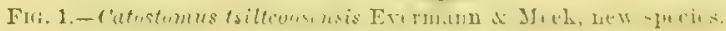

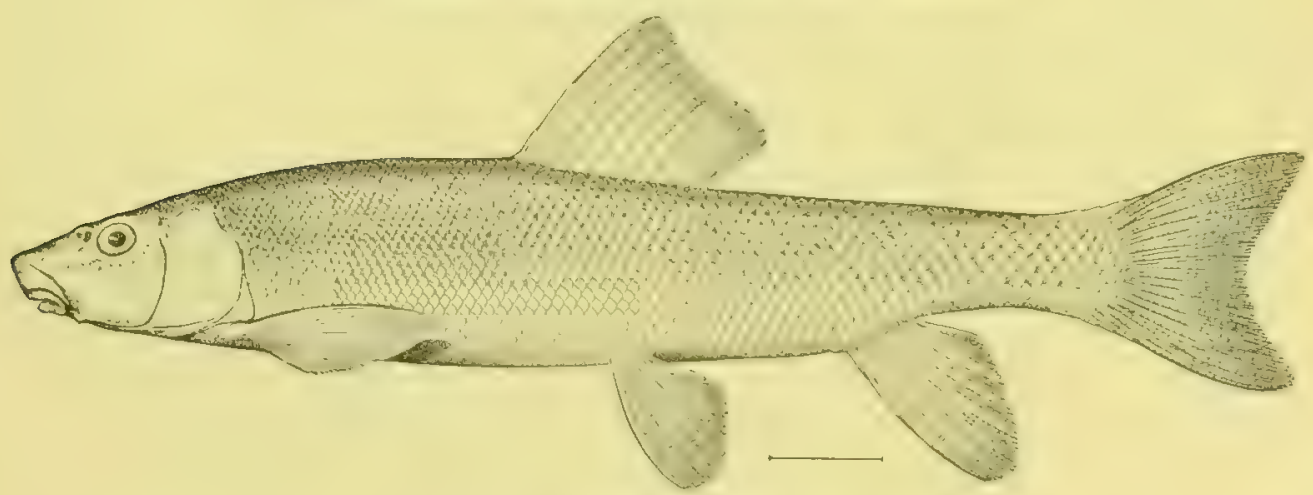

F1G. 2.Catostomus occidentalis Ayres.

5. Catostomus macrocheilus Girard. Columbia River Sucker" "Tellow Sucker."

Abundant throughout entiro Columbia River basin; obtained this year from Alturas and Wallowa lakes, in both of which it is abundant. It seems not to occur in siluslaw River, nor in Jakes of that part of Oregon. Wive specimens from Lake Union near Seattle, and one from Lake Washington at Seattle.

6. Catostomus snyderi Gilhert.

One obtaned from an Indian at the mouth of Williamson River, November 5. This species was caught, along with Chasmistes copei and Chasmistes stomias, in the small trap or basket nets which the Indians were using at that place. Three small specimens, $2:$ to 4 inches long, were taken in the seine at the south end of Upper Klamath Lake Norember 10 , and two others, 2 and $2 \frac{1}{2}$ inclues long, respectively, iu a slough at Pelican Bay November 3. No large examples seen in shallow water. 
The Klamath Lake Catostomus has been identified, by all who have had occasion to mention it, with C. labiatus Ayres, upon the supposition that the type of A Tres's species came from Kilanath Lake. But Ayres plainly states* that it came from Stockton, Califormia. As only one species of this genus is fonnd iu Sau Joagnin River, C. labiatus becomes a synonym of C. occidentalis, and the Klamath Lake species is left withont a name, a fuct first poiuterl out by Mr. J. O. Snyder, for whom the fish las been recently named by Dr. Gilbert.

The type specimen npon which Dr. Gilbert based his lescription is less than 8 inches long. As the

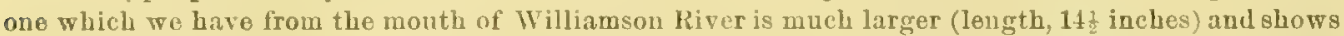
some slight differences, we describe it fully as follows: Head 4 ; depth 4 ; eye $6 \frac{1}{2}$ in head; snout $2 \frac{1}{2}$; maxillary $3 \frac{5}{5}$; mandible $2 \frac{1}{5}$; interorbital $2 \frac{1}{3}$; width of month $3 \frac{3}{2}$ in head, more than half length of snout; greatest width of lower lip 是 diameter of eye; 1). ii, 11; A. 7; scales 13-70-11. Body rather slender; head long, mouth moderate, horizoutal; lips thick papillose, the upper with about 4 or 5 rows of papilla, lower with about 7 ; lower lip divided nearly to base, leaving only one row of papilla crossing the symphysis; premaxillary not much projecting and not forming a prominent hump; maxillary rather short, not reaching vertical at front of anterior nostril; eye equally distant between snout and posterior edge of opercle; mucous canals on head forming raised ridges, the pores conspicuous. Fins moderate; origin of dorsal a little nearer snout than base of caudal, sixth spine over insertion of ventrals; pectoral $1 \frac{1}{4}$ in head, reaching slightly more than two-thirds distance to rentrals; ventrals not quite reaching vent, the seventh ray longest, $1_{i}^{3}$ in heid; anal long, pointed, reaching to base of caudal, $1 \frac{1}{6}$ in head. Scales crowded anteriorly, about 32 transverse rows in front of dorsal, strongly ridged, the marerins crenate.

\section{Chasmistes stomias Gilbert.}

One specimen, 15 inches long, obtained from an Indian at Klamath Falls, November 11. Head $4 \frac{1}{8}$; depth 41; ere 7; snout 23 ; maxillary (measured from free end to tip of snout) $3 \frac{1}{3}$; mandible $2 \frac{2}{3}$; D. ii, 11; A. i, 7; scales 13-85-10; interorbital width 21; verticat depth of beal at mandibular articulation 2!. Ileal suall, body heavy lorward, the back strongly and regularly arched from snout to origin of dorsal fin, thence declined in a nearly straight line to base of caudal; rentral surface nearly straight. Premaxillars spines strongly protruding, forming a prominently projecting snout; wouth ratler small, inclined upward at an angle of about 40, maxillary scarcely reaching vertical from front of auterior nostril; width of mouth $1 \frac{3}{5}$ in suout or $4 \frac{7}{5}$ in heal; upper lip thin, without papille; lower lip thin, interrupted at the symphysis, forming narrow lateral lobes the width of which is about 23 times in their length; faint indications of a few papillax; mucous canals forming ridges, the pores conspicuous; gill-rakers long, narrowly triangular at the tip when riewed from behind, rensely tufted on the interior edge; fontunelle narrow, its length $2 \frac{2}{3}$ in the snout, its width alont $\frac{1}{7}$ its length. Fins all large; the origin of the dorsal a little nearer tip of snout than hase of caudal, the sixth ray over base of ventral, its hase $1_{5}^{3}$ in head, the free edge nearly straight, the last ray $1_{5}^{3}$ iu the tirst, which is $1 \frac{1}{2}$ in head; pectorals scarcely falcate, reaching a little more than two-thiris distance to base of ventrals, their length 1 in heal; veutrals long, reaching vent, the rays gradually increasing in length from the outer to the seventh and eighth, which are longest, the ninth and tenth being but slightly shorter, the length of the longest ray $1^{3}$ in head or alout $\frac{1}{5}$ longer than the first; anal long :ud pointed, the fourth ray longest, reaching base of caudal, $1 \frac{1}{6}$ in head; each luy of anal fin with 8 to 12 strong tubercles; caulal lohes about erual, their length 1 g times the midhle ray.

This specimen agrees with Dr. Gilluert's type, with which we have compared it. In the type the mouth is rather more oblique, the maxillary is slightly longer, and the anal fin is louger.

8. Chasmistes copei, new species. Kilamath Indian name "Truam."

'Ty no No. 18224, U. S. N. M. (collectors' No. 871), a specimen 16 inches long. Type locality: Nortbwest part of Pelican Bay, Upper Klamatl Lake, Oregon; collected (iu gill net) November 6, 1896, by Messrs. S. E. Meck and A. B. Alexander.

Heal $3 \frac{2}{3}$; depth 4; eje $6 \frac{1}{5}$; snout $2 \frac{1}{2}$; maxillary (measured from free end to tip of snout) 3 ; mandible 2 ; 1 ). ii, 10 ; A. i, 7; scales 13-80-12; interorbital width 27 ; vertical depth of head at mandibular articulation 21. Ilead large, eheek very (leep, the depth equal to distance from tip of suout to nostril; bolly stout, back scarcely elevated, candal peduncle rather short and stout; rentral surface somewhat convex. P'remaxillary spines less protruding than in $C$. stomias, not forming a prominent

* Proc, Cal. Ac. Nat. Nici., I, 185:, 33

中 Bull. U. S. F. C. 1897, 3.

Deseribed in Bull. U.S. F. C. $1 \notin 97,5$, with figure. 
hump; mouth large, inclined upward at an angle of 450 , maxillary not nearly reaching vertical at front of anterior nostril; width of month 1. in snout, or 4 in head; upper lip thin, without papillat; lower lip thin, entirely without papille, interrupted at sywphsis, forming rather broad lateral lobes; pores on head very conspicuous; gillrakers larger than in $C^{\prime}$. stomias, broadly triangular at tip when viesved from behind, densely tufted on anterior edge, each appendage more or less bifid and club shaped, closely

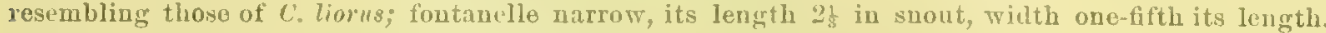
Fins all small; origin of dorsal a little nearer snout than base of caudal, its sixtl ray over base of veutrals, free edge straight, base $2 \frac{1}{3}$ in heal, last ray a little less than 2 in first, which is 2 in head; pectorals somewhat falcate, reaching slightly more than half distance to ventrals, their leucth $1_{5}^{3}$ in heal; ventrals very short, reaching only two-thirds distance to vent, free end nearly straiglit; nuter ray longest, 27 in head; inner shortest, 3 ; in heal; anal fin short, bluntly pointed, not reaching base of candal, third and fourthrays longest, 1 in heal; no tubercles on anal rays; caudal lobes equal, length about 1 times the widlle ray. Scales small and crowded anteriorly, about 14 rows downward ant? backward from front of dorsal to lateral line, 11 vertically upward from base of ventral to lateral line, about 38 oblique series before dorsal; lateral line uearly straight, with about 80 scales. Eutire upper parts of head and boly, and side's nearly to lovel of base of pectorals, dark olivaceous; under parts auruptly whitish or jellowish in alcohol; a dark spot in upper part of axil; dorsal aud caudal dark; pectorals dark on inuer surface; ventrals and anal plain.

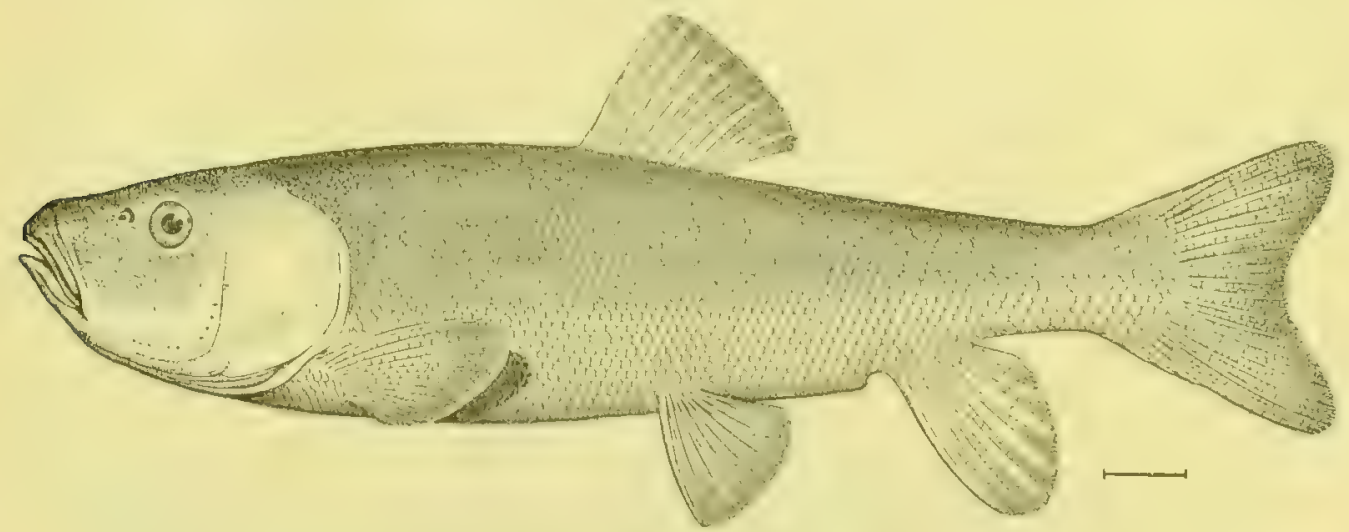

Fin. 3.-Chasmistes copei Evermann \& Meek, new species.

From Chasmistcs slomias this species is readily distinguished by its larger head, larger, more oblique mouth, less prominent snout, and very small fius. The differences in the fins are very great, particularly in the ventrals, as way be seen iu the accompanying illustrations. It difiers from $C$. brerirostris, as characterized by Dr. Gilbert, in its much larger, more oblirue mouth, tho absence of papille on the lips, and shorter fins.

We name this species for the late Prof. Edward Drinker Cope, who wrote the first paper on the tishes of Uprer Klamath Lake.

Six nominal species of suckers have thus far been described from the Klamath Lakes, viz: Chasmistes luxatus and Chasmistes brevirostris by Cope in 1879; Catostomus rex by Rosa Smith Eigenmann in 1891; Catostomus snyderi and Chasmistes stomics by Gilbert, and Chasmistes copei by Evermann of Meek, the last three in the present Bulletiu. Mr. A. Sealo has recently taken C. luxatus as the trpo of his new genus Dettistes, which he bases upon the peculiar structure of the gillrakers. Dr. Gilluert finds that Catostomus $r e x$ is a synouym of Deltistes luxatus. As now understood, we therefore know from Upper Klamath Lake one species of Calostomus, one of Deltistes, and three of Chasmistes.

9. Mylocheilus caurinus (Richardson). Columbia Chub.

Obtained from Little White Salmon River, Lakes Washington and Sammamish at Seattle, and Lake Pend d'Oreille at Hope, Idaho. Abundant early in September in lagoon at mouth of Little Whito Salmon River, and seen in considerable numbers at steamloat landings between Portland and The Dalles. It does not occur in the Redfish Lakes in Irlaho, nor has it been recorded from Wallowa Lake, nor from any of the streams or lakes south of the mouth of the Columbia. 
10. Ptychocheilus oregonensis (Richardson). Squawfish; Fellowbelly.

This large minnow is abundant throughout the Columbia Rirer basin except the portion above Shoshone Falls. In Montana, and perhaps elsewhere, it is called "squawfish"; at Sawtooth, Idalo, it is known only as "yellow belly"; at Mapleton, Oregon, "chub" was the only name heard applied to it; while at Tsiltcoos Lake it was called "dace." Specimens obtained from Lakes Alturas, l'end d'Oreille, Gamlin, Washington, Tsiltenos, Whoahink, and Talkenitch, and from Siuslaw River. One was taken on a set line in Whoahink Lake, at a depth of 78 feet, on December 3.

Scale and fin formule and comparative measurenents of specimens of $I$. oregonensis from Lake Thashington.

\begin{tabular}{|c|c|c|c|c|c|c|c|c|c|c|c|c|c|c|c|}
\hline $\begin{array}{l}\text { Length } \\
\text { in } \\
\text { inches. }\end{array}$ & Head. & Depth. & Eye. & Snont. & $\begin{array}{l}\text { Dor- } \\
\text { sill. }\end{array}$ & Anal. & Scales. & $\begin{array}{l}\text { Length } \\
\text { in } \\
\text { inches. }\end{array}$ & Fread. & Depth. & $\mathbf{E} \Gamma \theta$. & Snout. & $\begin{array}{l}\text { Dor- } \\
\text { sal. }\end{array}$ & Anal. & Scales. \\
\hline $\begin{array}{l}7.25 \ldots \\
7.75 \ldots \\
7.00 \ldots \\
5.75 \ldots \\
5.88 \ldots \\
5.50 \ldots\end{array}$ & $\begin{array}{l}3.61 \\
3.67 \\
3.50 \\
3.57 \\
3.41 \\
3.67\end{array}$ & $\begin{array}{l}5.33 \\
5.00 \\
5.00 \\
5.00 \\
5.00 \\
5.00\end{array}$ & $\begin{array}{l}\text { 5. } 60 \\
5.80 \\
5.60 \\
\text { 5. } 17 \\
5.00 \\
5.00\end{array}$ & $\begin{array}{l}1.80 \\
2.00 \\
1.80 \\
1.67 \\
1.50 \\
1.50\end{array}$ & $\begin{array}{l}10 \\
10 \\
10 \\
10 \\
10 \\
10\end{array}$ & $\begin{array}{l}9 \\
9 \\
9 \\
9 \\
9 \\
9\end{array}$ & $\begin{array}{l}76 \\
80 \\
77 \\
74 \\
74 \\
75\end{array}$ & $\begin{array}{l}5.25 \ldots \\
5.00 \ldots \\
4.63 \ldots \\
4.38 \ldots \\
4.38 \ldots \\
3.17 \ldots\end{array}$ & $\begin{array}{l}3.78 \\
3.60 \\
3.83 \\
\text { 3. } 83 \\
3.67 \\
3.60\end{array}$ & $\begin{array}{l}5.00 \\
4.86 \\
4.75 \\
4.67 \\
4.67 \\
4.60\end{array}$ & $\begin{array}{l}5.00 \\
5.25 \\
5.00 \\
4.67 \\
5.00 \\
4.60\end{array}$ & $\begin{array}{l}1.42 \\
1.67 \\
1.67 \\
1.50 \\
1.50 \\
1.40\end{array}$ & $\begin{array}{l}10 \\
10 \\
10 \\
10 \\
10 \\
10\end{array}$ & $\begin{array}{l}9 \\
9 \\
9 \\
9 \\
9 \\
9\end{array}$ & $\begin{array}{l}77 \\
74 \\
76 \\
74 \\
77 \\
78\end{array}$ \\
\hline
\end{tabular}

11. Leuciscus bicolor (Girard).

Judging from our collections, this is the most abundant minnow in Upper Klamath Lake. About 60 were obtained at the lower end of the lake November 10, and over 100 from a small creek at Pelican Bay Norember 5. At the time of collecting this species was found in the sluallow water of the little creeks and passages among the tules. The largest are 9 to 10 inches long, but only a few exceed 3 inches. Examples 2 to 3 inches long gave the following measurements: Hearl 4 ; (lepth 5 ; eye 32 to $3 \frac{3}{5}$; snont $4 \frac{2}{5}$ to $4 \frac{1}{2}$; scales 59 ; teeth 2,5-5, 2. See illustration on page 7 of this Bulletin.

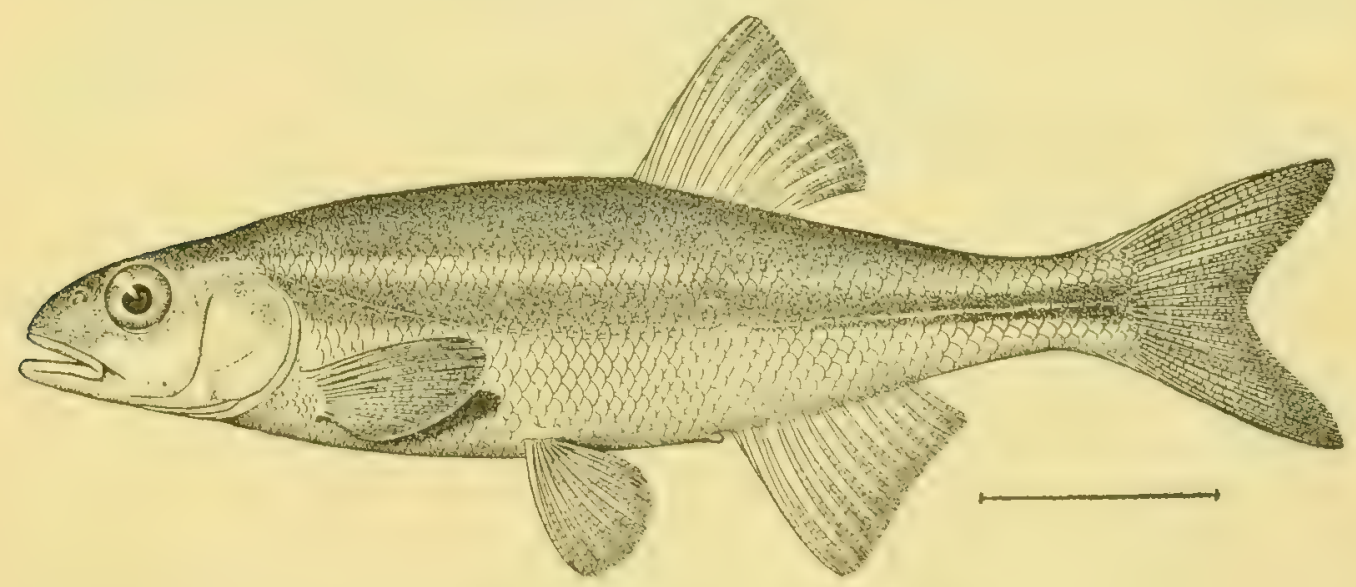

FIG.4.-Ietuciscus siuslawi Evermann \& Meek, new species.

12. Leuciscus sinslawi, new species.

Туре No. 48180, U. S. N. M., a specimen 5 inches long. Cotypes No. 433 U. S. F. C.; No. 48231, U.S.N.M., and No. 5702, L. S. Jr., Univ. Mus. Typo locality: Sinslaw River at Mapleton, Oregon. Collected September 8, 1896, hy S. E. Mcek.

Head $4 \frac{1}{5}$; deptl $4 \frac{1}{6}$; eje 4 ; snout $3 \frac{1}{2}$; maxillary 3 ; $;$ D. ii, 9 ; A. ii, 12 or 13 ; scales $11-58-8$; teeth $2,4-5,2$, somewhat looked.

Boly rather slender, slightls elerated and somewhat compressed; head small and pointed, cheek not deep; snout pointed, somewhat longer than eje; mouth moderate, somewhat oulique, maxillary just reaching vertical at front of orbit; jarrs subequal, the lower sometimes slightly projecting; eye large, not as great as snont. Origin of dorsal tin behind base of ventrals and much nearer baso of caulal than tip of snout, the longest ray $1 \frac{1}{2}$ in head, orreater than base of fin; origin of anal fin under 
last dorsal ray but two, its lieight equal to that of dorsal, its base equal to its longest ray; free edges of dorsal and anal nearly straight; nectoral $1 \frac{1}{4}$ to $1 \frac{1}{2}$ in head, not reaching insertion of ventrals; ventrals short, $1 \frac{1}{5}$ in pectoral, reaching anus; candal deeply forked; lateral line completo, decurved; color in spirits, brownish or olivaceous ahove, middle of side with a broad dark band involving the lateral line anteriorly and posteriorly, lut lying ehiefly above it mesially; middlo of side from gill openiug to beneath dorsal fin with a broad rosy band, following closely beneath the lateral line; lower part of sides and under parts silvery, dusted over with fine dark specks; a light jellowish band extending backward from upper posterior borker of eye nearly halfway to origin of ilorsal fin; cheek with a silvery or golden crescent; top of head dark; opercles dusky silvery; snout dusky; fins plain, dorsal and candal somewhat dusky. Numerous specimens were obtained in the Sinslaw River anil one from Tsilteons Lake.

At Mapleton both this minnow and Ptychocheitus oregonensis are known as "chub," while on the lakes south of Florence they are called "dace." It is probably common in these lakes, but a single specimen only was obtained there.

Compared with Lenciscus balicatus, which our specimens most closely resemble, the latter are seen to have smaller anal and dorsal fins, a more slender hody, smoller and more slender heâd, and longer, more pointed snout. The extent of variation in proportional measurements and in the number of anal fin rays appears to be much less than in $L$. balteatus.

This species also resembles Leuciscus cooperi of Girard. In the type of $L$. cooperi (No. 238, U.S. N. M.) the lower jaw is notably shorter aud the snout more pointed.

In the following statement will be found measuremeuts of a number of specimens from Sinslaw River, Mapleton, Oregon:
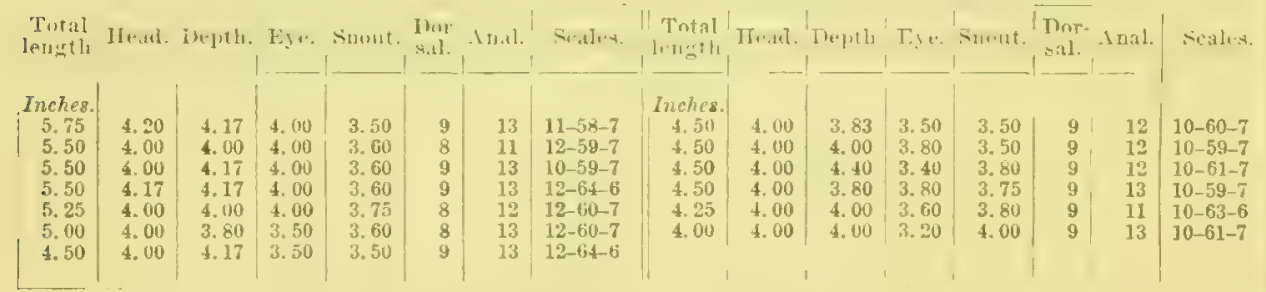

The anal fin rars were counted in 16 additional specimens with the following results, the average for the total 29 specimens being 121 :

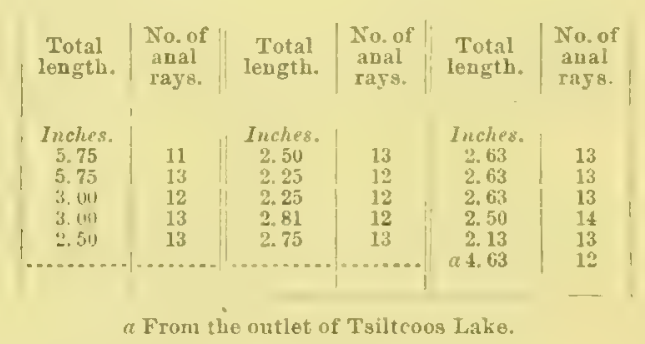

13. Leuciscus balteatus (Richardson).

Abundant throughout the Columbia River basiu except above Shoshone Falls. Specimensobtained from Alturas, Pend d'Oreille, Gamlin, and Washington lakes. The variation in the number of anal fiu rays of specimens from these localities is shown in the following table. The length is measured from tip of snout to base of caudal fin. The last ray, though usually leeply divided, is counted as one. There are usually two rudimentary rags at front of fin, which are not counted. Of 30 specimens from Gamlin Lake, 1 has 13 rays, 7 have 15, 14 have 16, 4 have 17, and 4 have 18, the average being 16 rays. Of 10 specimens from Lake Washington 5 have 11 rays, 3 have 15 , 1 has 16 , and 1 has 18 , the average being 15 rays. 
Table showing raviation in the number of rays in the anal fin in Leuciscus balleatus.

\begin{tabular}{|c|c|c|c|c|c|c|c|}
\hline \multirow[b]{2}{*}{$\begin{array}{l}\text { Length } \\
\text { in } \\
\text { inclies. }\end{array}$} & \multicolumn{4}{|c|}{ Gamlic Lake. } & \multicolumn{3}{|c|}{$\begin{array}{l}\text { Lake Trash- } \\
\text { ington. }\end{array}$} \\
\hline & Anal. & $\begin{array}{l}\text { Length } \\
\text { in } \\
\text { inclies. }\end{array}$ & Anal. & $\begin{array}{c}\text { Length } \\
\text { in } \\
\text { inclies. }\end{array}$ & Anal. & $\begin{array}{c}\text { Length } \\
\text { jn } \\
\text { inches. }\end{array}$ & Anal." \\
\hline 1. 88 & 16 & 1. 63 & 16 & 1.75 & 16 & 2. 75 & 15 \\
\hline 1. 88 & 16 & 1.50 & 16 & 1.75 & 18 & 3.13 & 14 \\
\hline 1.88 & 16 & 2.00 & 18 & 1.75 & 15 & 2.50 & 14 \\
\hline 1.88 & 17 & 2.13 & 15 & 2.00 & 16 & 3.13 & 15 \\
\hline 1.75 & 15 & 1.75 & 17 & 2.00 & 16 & 3.13 & 14 \\
\hline 2. 00 & 16 & 1. 86 & 16 & 1. 63 & 18 & 3.50 & 11 \\
\hline 1.88 & 15 & 1.88 & 18 & 1.88 & 16 & 3.50 & 16 \\
\hline 1. 75 & 16 & 1. 75 & 15 & 1. 75 & 13 & 4.00 & 15 \\
\hline 1. 75 & 17 & 1.75 & 17 & 1. 50 & 15 & 3.75 & 18 \\
\hline 1. 63 & 16 & 1. 75 & 15 & a 4.75 & 16 & 3. 88 & 14 \\
\hline
\end{tabular}

a From Lake l'end d'oreille.

14. Rutilus bicolor (Girard).

Numerous specimens obtained in a slough at Pelican Bay and others at the south end of Upper Klamath Lake. Some were caught in a gill net, others in a small dip net, such as is used by Klamath Indians; a fow were taken on a set line, but the majority were obtained by means of a small seine, in small sloughs or lagoons at the sonth end of Upper Filamath Lake. It seems to be one of the most abundant species occurriug in the lake. The largest measure about 9 inches in total length. There does not appear to be much variatiou in the number of scales or fin rays, or in proportional measurements, as is shown in the following table. The Inclians use this species for bait when fishing for tront near Klamath Falls, the average length of those thus used being about 4 inches. It is caught in large numbers in dip nets in the elge of the tules. This species is figured on page 8 of this Bulletin.

Table shoxing variation in 13 specimens of Lutilus bicolor from Lpper Kilamath Lake, Oregon.

\begin{tabular}{|c|c|c|c|c|c|c|c|c|}
\hline $\begin{array}{c}\text { Length in } \\
\text { inches. }\end{array}$ & Head. & Depth. & Eye. & Snout. & $\begin{array}{l}\text { Maxil- } \\
\text { lary. }\end{array}$ & Dorsal. & Anal. & Scales. \\
\hline 9.00 & 3.75 & 3.75 & 7.00 & 3.50 & 4.00 & 9 & 8 & 49 \\
\hline 9.25 & 3.75 & 3.67 & 6.00 & 3.50 & 3. 75 & 9 & 8 & 49 \\
\hline 6.00 & 3. 75 & 3. 75 & 5.50 & 3. 75 & 4. 25 & 9 & 8 & 48 \\
\hline 4.50 & 4.00 & 4. 00 & 4. 50 & 4.00 & 4. 20 & 9 & 8 & 47 \\
\hline 4.50 & 3.75 & 3.75 & 4.50 & 4. 00 & 4.25 & 9 & 8 & 48 \\
\hline 4.25 & 4.01) & 4. 00 & 4. 50 & 4. 00 & 4.25 & 9 & 8 & 46 \\
\hline 5.25 & 3.50 & 4.00 & 5. 100 & 3.50 & 4. 33 & 9 & 8 & 48 \\
\hline 3.75 & 3.50 & 4.00 & 4. 25 & 3.67 & 4. 25 & 9 & 8 & 49 \\
\hline 3.75 & 3.50 & 4.00 & 4. 50 & 4.00 & 4.00 & 9 & 8 & 44 \\
\hline 3.50 & 3.50 & 3. 75 & 4. 25 & 4.00 & 4.50 & 9 & 8 & 46 \\
\hline 3.50 & 3.50 & 4.25 & 4. 20 & 4.00 & 4. 33 & 8 & 7 & 47 \\
\hline 3.50 & 3.67 & 4. 25 & 4. 00 & 4.00 & 4. 25 & 9 & 7 & 47 \\
\hline 2.50 & 3.60 & 4. 33 & 3.50 & 4. 50 & 4. 25 & 9 & 8 & 46 \\
\hline
\end{tabular}

\section{Rhinichthys dulcis (Girard).}

One specimen from Wallowa Lake. The origin of the clorsal is midway between tip of snout and base of caudal peduncle.

16. Agosia klamathensis, new species

Type No. 482:5, U. S. N. II.; cotspes No. 5704, L. S. Jr. Univ. Mus. and No. 451, U. S. F. C. Type locality at mouth of the small creek which flows into the arm of Upper Kilamath Lake called Peliean Bay, where numerous specimens were collected November 3, 1896, hy J)r. Seth E. Meek and Mir. A. B. Alexander. Length of type $2 \frac{1}{2}$ inches, measured to last caudal vertebra.

close to Agosia nubila.

An examination of a large series of specimens of d/gosia from Upper Klumath Lake aud a comparison of them with specimens of $A$. mubila from various localities show the fish from this lake to possess certain characters which serve to distinguish it from typical 4 .nubila. While the difierences are slight, they are plainly evident aud must be recoguized, and we therefore lescribe this form as a new species.

Head 4 ; depth $4 \frac{1}{2}$; eye $4 \frac{1}{2}$ in head; snont $3 \frac{1}{2}$. D. i, 8 ; A. i, 7 ; scales about 1t-78-10 (average, 73 in 49 specimens). 
Body robust, subcylindrical, back somewhit elevated; snont rather long, mouth inferior, little oblique, the lower jaw included; maxillary not reaching front of orlit; upper lip without frenum; barbel present, but small. Lateral line iucomplete, interrupten in many places, about 30 pores developed. Oriwin of dorsal fin midway between front of pupil and base of caudal fiu; pectorals rathor short, reaching about three-fourths the distance to base of ventrals; ventrals reaching vent; anal largo, its longest ray $1 \frac{1}{2}$ in liead; cauchl widely forked.

Color in alcohol, olivacenus, mottled and blotched with darker on back and sides; under parts pale; an obscurepale streak from eye to base of caudal fin, below which is a broad dark band; dorsal, poctorals, and caurlal dusky; other fins plaiu; a black blutch at baso of candal.

An examination of the 48 specimens which we designato as cotylus shows all the important characters to be fairly constant. The barbel is in a few cases olvscure or possibly absent. The number of scales in a transverse line varies from $6 x$ to 78 , the average being 73 . T'le lateral line is in all cases incomplete, though in different degrees; sometimes it is continuous for only 6 or 8 scales, after which there are several interruptious and only 8 to 10 more pores; in others thero are 20 to 30 pores in a continuous series.

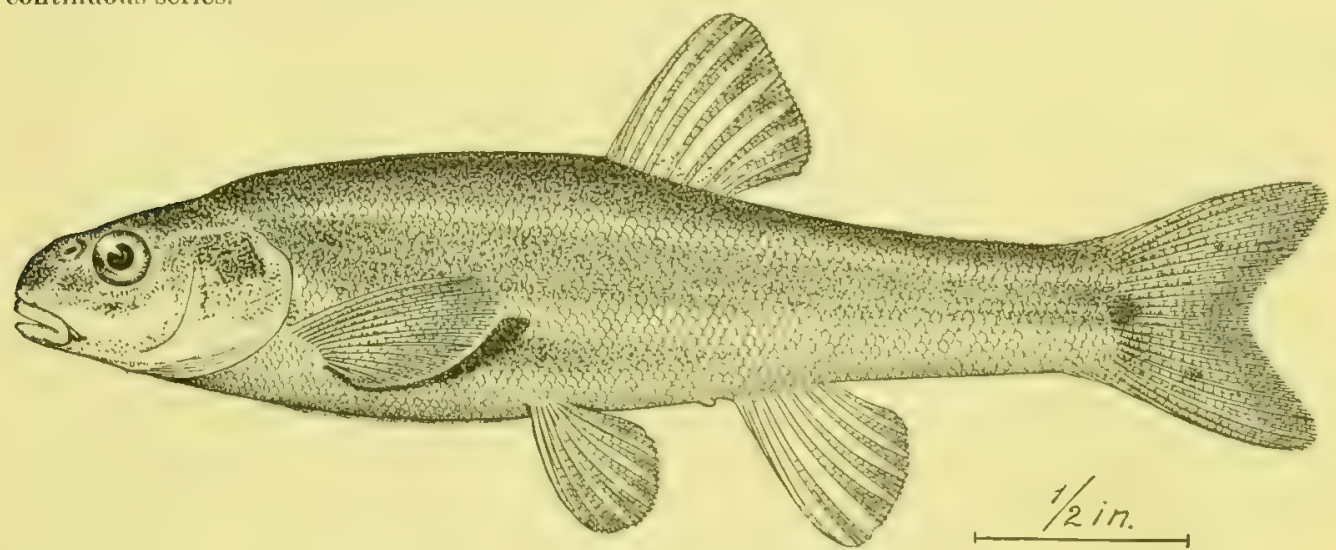

FIG. 5,-Agoria Klamallensis Erermann \& Meek, new species.

This form is distinguished from Agosin nubila chietly by the smaller size of the scales. 'This difference will appear from an examination of the tabular statement which follows:

Table showing number of scales in Agosiu nubila and Agosia klamathensis.

\begin{tabular}{|c|c|c|c|}
\hline Locality- & $\begin{array}{l}\text { No. of } \\
\text { specimens } \\
\text { oxamined. }\end{array}$ & $\begin{array}{l}\text { Yariation } \\
\text { in number } \\
\text { of scales. }\end{array}$ & $\begin{array}{l}\text { Average } \\
\text { number } \\
\text { scales. }\end{array}$ \\
\hline \multicolumn{4}{|l|}{ Agosia nubila: } \\
\hline $\begin{array}{l}\text { Colville River, Meyers Falls } \\
\text { Little Spokane Iiver, Dart's Mill.............. }\end{array}$ & $\begin{array}{l}6 \\
9\end{array}$ & $\begin{array}{l}52-57 \\
52-63\end{array}$ & 55 \\
\hline Hangman Creek, Tekoa, Wash........... & 10 & $51-65$ & 57 \\
\hline 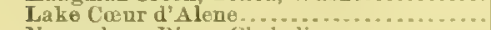 & 9 & $6 \downarrow-70$ & 66 \\
\hline Nervaukum River, Chehalis.......... . & (3) & $53-58$ & 55 \\
\hline Boise River, Caldwell......................... & 1 & 56 & 56 \\
\hline Potlateh Creek, Lew iston. ................... & 10 & $60-66$ & 62 \\
\hline Pataha River, Starbuck .................... & 9 & $60-64$ & 62 \\
\hline Walla Walla River, Wallula.............. & 15 & $47-55$ & 49 \\
\hline Mill Creok, Walla Walla.................... & 20 & $52-61$ & 55 \\
\hline Umatilla River, Pendleton.................. & 3 & $48-58$ & 52 \\
\hline 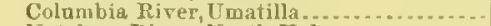 & 7 & $48-57$ & 53 \\
\hline Natchess River, North Yakama ............. & (?) & $53-58$ & 56 \\
\hline Shookumehuck Rirer, Chobalis............ & 6 & $50-57$ & 55 \\
\hline \multicolumn{4}{|l|}{ Agosia klamathensis: } \\
\hline Pelican Bay, Upper Klamath Lake.... & 49 & $68-78$ & 73 \\
\hline
\end{tabular}

17. Clupanodon caruleus (Girard). California Sardine.

Very abuudant in Sinslaw River abont the canvery wharf at Florence during the canning season. It seems to disappear as $800 \mathrm{n}$ as the fall rains set in and the river becomes filled with fresh water. The specimens seen were each about $2 \frac{1}{2}$ inches in length. 
18. Alosa sapidissima (Wilson). Common Eastern Shad.

During the silmon fishiug season of 1896 in the siuslaw River about a dozen shad were takenone in a salmon gill net near Mapleton about the widdle of October, the others in salmon seines at Acme in September and October. The specimeu caught near Mapleton is a male 18 inches long and weighing abont 21 pounds. The spermaries are but slightly developed, indicating that the spawning season would be some months arlier than when this fish was taken. Head 4; depth 3 ; orbit $4 \frac{1}{3}$; snout $4 \frac{3}{5}$; mitxillary 2 ; gill-rakers $35+68$ on the left and $36+68$ on the right.

The first planting of shad on the Pacific const was male in 1871 by Mir. Seth Green, who liberated alont 10,000 fry in the Sacramento Liver 275 miles above Sacramento. The second plant was made in July, 1873, by Mr. Livingston Stone, who placed 35,000 fry in the Sacramento River at Teluama. Various subsequent plants have been malle by the U. S. Fish Commission in California, all at Tehama, the last plant having been made in 1880. Beside's these plants uale in the Sacramento River, 60,000 fry were placed in the Willamette River at I'ortland and 10,000 in Snake River in 1885. In 1886, 550,000 fry were liberated in the Willamette River at Albany, and 300,000 in the Columbia at Wallula Junction. In 1881, 1885, and 1886, 2,651,000 shad fry were placell in the Coloralo liver at The Needles, Arizona. No investigation has ever been made for the purpose of determining the result of the plantings inale in the Colorado hiver and it is not known whether any of the fry surviver. The results from the plants male in California and Oregon, however, are little less than marvelous, as shown by Dr. H. M. Suith in a recent paper. *

From the Sacramento and Columbia rivers shad have spread to Los Angeles County, California, on the sonth, and Wrangeil Island, Alaska, on the north. They had spreal from San Francisco to the Columbia River as early as 1880 , and by 1882 had been taken at various places along the Washington coast. The only passages through which the planted shat could reach the sea are the wouth of the Columbia River and the Golden Gate. From these points they have spread up and down the Pacific coast a distance of more than 1,300 miles. 'This is greater than its range in latitude on the Atlantic const. Not only have they sprearl to these distant points, but shail have been reported from a number of intermediate places, among which are Monterey Bay, Drake Bay, Klamath River, Rogue River, Umpqua River, Siuslaw River, Fraser River, and the north end of Vancouver Island.

These facts in the distribution of the shad on the Pacific coast aro of extreme interest and importance as learing directly upon the belief, still more or less prevalent, that analromous fishes possess a mysterious geographic instinct which leads them back to the stream in which they were spawner. While the number of shad entering the Columbia and San Francisco Bay is far greater than that for all the other rivers combined, it is nevertheless true that many shad have found their way to other and distant streams. The extent to which this has occurred seems to us fully suficient to disprove the possession by the sharl of any "special geographic instinct." We belicre the same to be true of the varions kinis of salmon and other anadromous species. The question is in need of further research, but investigations already made indicate that andromous lisbes, like migrating birds, are guided iu their movements by landmarks or other tangible physical features or conditions.

The young shad hatched in any given stream go down to the sea, but probably do not ordinarily wander far from the mouth of that particnlar river. When they become mature, and phjsiological unrest, due to the development of the reproductive argans, cumes on, they begin to search for suitable spawning-bels, aud the chances are they will find the river in which thoy were hatched. The majority will find this stream, while those that wandered farthest from its mouth may find others which they will enter.

19. Coregonus williamsoni Girard. Rochy Mountain Whitefish.

Common throughout the Columbia River basin. Specimens obtained from Alturas, Pend d'Oreille, and Wallowa lakes, Des Chutes River at Sherar's Brirlge, and Big White Salmon River. A specimen

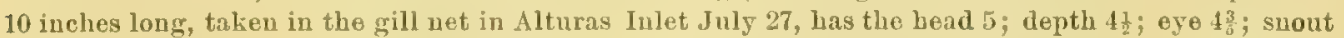
33 ; maxillary $3 \frac{3}{5}$; D. 12; A. 11; scales 86 .

Another example, a female, $12 \frac{1}{4}$ inches long and with well-developed roe, was taken with the hook

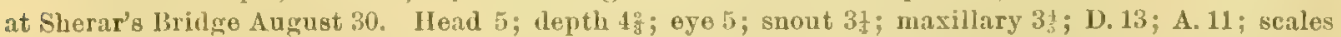
88. In this specimen the adipose lin is remarkably large, its base being half length of head, its height $6 \frac{1}{2}$ in head. This species spawns in October at Big l'ayette Lake, in Idaho, but the condition of the ovaries of the specimen taken at Sherar's Brilge indicates a much earlier spawning period.

"A Review of the History" and Results of the Attempts to acclimatize Fish and other Water Auimale in the Pacific states, in Bull. U. S. F. C. 1895, 407. 
20. Oncorhynchus keta (Wallaum). Dog Salmon.

According to Mr. Altsander, this salmou usually commences to run in the southern part of Puget Sound about the middle of Octolver and continues until the first of December. In 1895 and 1896 they were quite numerous. During fall and winter all the small creeks, lagroous, and sloughs near Duwamish and Cedar rivers are filled with log salmon, aul bogs find great amusement killing them with clubs and stones. In the rivulets by the roadside, where the water is not over 2 or 3 inches deep, dog salmon mar be seen trying to get farther upstrearu. At such times they are in poor condition and no use is marle of them.

The condition of the dog salmon in January, 1897, was unusually good. These fish were plump in appearance and marked with that lurightness which they possess when first coming from the ocean. In the opinion of some of the dealers many of the January (1897) run were fresh from the ocean. Their egge, like those of the steelbead, shorred varions degrees of development; most of the tish were well advanced, however. It has been ouly a fow years since it was known that any species other than the steelhead was to he found in I'uget Sound duringr winter, lut it is now thought that salmon have always been more or less plentiful in P'nget Sound during the winter months-not a heary run, but enough to supply the local demand. In former years, there being no sale for salmon after the cauneries were closed, fishing was alnost wholly suspencled until the next senson. As soou, however, as the experiment of shipping fresh salmon to eastern markets proved a success, a new industry was opened, and fishermen who had hitherto given no thought to winter lishing now began to investigate the waters of l'uget Sonnd ont of season, and the result is that a winter fisliery of considerable importance has heen introduced in Seattle and other places on the sound and is increasing rearly. The steelhead is the uost valuable fish for shipment to eastern markets, as it reaches its destination in better condition than other species.

21. Oncorhynchus tschawytscha (Walbaum). Chinook salmon.

Very few chinook salmon camo to the headwaters of Salmon Rircr in 1896, perhaps not over a ¿lozen, where there were about 1,000 in 1895. 'Tho number which came to the 11 allowa spawning-heds was also very small. Important sparning-heds were found in Little White Salmon River, and considerable numbers were found spawning in Jigr White Salıon River, Eagle Creek, and Tanner Creek.

Foung chinooks were found in Siuslaw River in consiclerable numbers and a fow were obtained in Lake Washington. Two specimens, $2 \frac{1}{3}$ and $2 \frac{2}{8}$ inches in length, respectively, from the mouth of $\mathrm{Big}$ White Salmon agree perfectly with those gotten in 1895 at Alturas Lake. These two specimens were evidently hatcherl the preceding winter.

Nine specimens from the Siuslaw River, canght with hook and line at Florence, October 14, 1896; leugth, $5,5 \frac{1}{1}, 6,6 \frac{1}{2}, 6 \frac{1}{2}, 7,7,7$, and $7 \frac{1}{2}$ inches respectively. Salmon of this size are very abundant about the cannery wharf during the canning season. They are easily caught with hooks baited with salmon eggs.

Two specimens 11 and $11 \frac{1}{2}$ inches in length from Seattle, Washington, caught December 8, 1896. These specimens were no doubt hatched during the winter of 1894-95. One specimen, 6 inches long, was taken with a seine near the mouth of the Sinslaw IRiver December 9, 1896. It is the same age as the specimens mentioned above from Florence. One small, nearly ripe male, length 18 inches, from the Siuslaw River at Mapleton, Oregon, wis caught on a hook baited with salmon eggs. A few other specimens of the same size were caught in the same way while fishing for trout about October 21 . We are informed that it is not uncommon to eatch these fish with baited hooks.

A few of these small male salmon were seen on the spawning-beds in the North Fork, near Minerva, October 23 and 24. They were mutilated the same as the larger ones, and one was in a dying condition.

On September 9 Mr. A. B. Alexander examined 129 chinook salmon in the Florence cannery; of these 76 were females and 53 were males; 25 of the females and 13 of the males were fully develoned. On September 11 he examined 546 chinooks; of these 317 were females and 229 males; 229 females and 110 males were nearly ripe. There were among this unmber 25 small fish from 18 to 25 inches in length; these were as fully developed as the largo ones.

During the latter part of September and enty part of October, Mr. Alexander examined many chinook salmon at Celilo and obtained much valuable information as to their spatrning condition. In one lot of 119 fish examined 57 were males and 62 females; 34 males and 47 females were nearly or quite ripe, and would have slutwael by the sth or 10 th of October.

In the following tables is given a recorl of the fish examined by Mr. Alesander. 
Chinook salmon talien in fish-whels by Mr. I. H. Tafle, Celilo, Oregon, September 1S to 22, 1896.

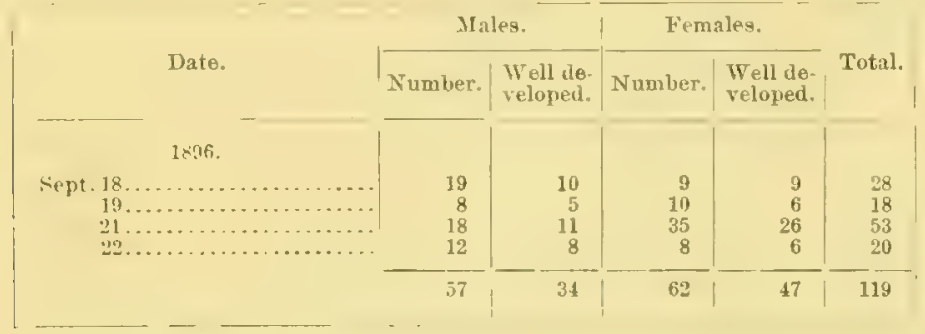

Anong the 119 chinook salmon, 13 small ones were found, all males, and their milt as fully developed as that in larger fish. Sometimes the wheels take these fish in considerable numbers.

Chinool salmon takun by Mr. F. A. Seufert, at Celito; Oregon, September 25 to October 13, 1896.

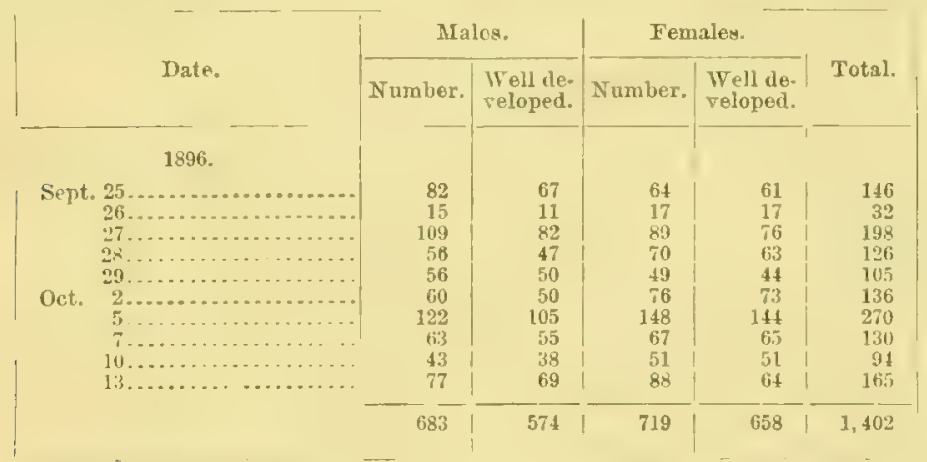

In a total of 683 males and 719 females Mr. Alexander found 574 males and 658 females which, in his judgment, were nearly ripe. In other words, 81 per cent of the males and 90 per cent of the females would have spawned betwecu the first and middle of October. These observations indicate that chinook salmon can be obtained abundantly at Celilo by wheels and that if retainer a few days they would be ripe enough for stripping. Whether the wheels serionsly injure the fish can be determined only after actual experiment with tish so caught. If the wheels do not injure them they can probably be kept until fully ripe in properly constructed retainiug boses or ponds, as was demonstrated by experiments at Mapleton, Oregon.

According to Mr. Alexander clinook salmon appear in the lower part of Puget Sound about the Ist of May and continue to increase in numbers until July. Scattering ones are taken, however, throughout the year in all parts of the sound.

22. Oncorhynchus kisutch (Walbaum). Silier satmon.

Our collection contains specimens of this species as follows:

Three ripe males, one 16 inches in length, canght December 1 in Whoahink Lake, the other two, 16 and $17 \frac{1}{2}$ inches respectively, December 3 , in 'T'siltcoos Lake. Specimens of this size and rery much smaller were frequently caught in the seine at Acme. Not less than 50 of these were examined. All were males with sexual organs as highly developed as in the larger ones.

One large ripe male from Tsiltcoos Lake, caught in a gill net December 3, 1896. Immaculate, back with a bluish tinge, borly bright red, mouth much distorted. Locally called "hookbilled silverside."

There is a moderately small form of the silver salmon in the Sinslaw River called blueback, which resemble the true blueback in size, form, and color, but are more spotted. Two specimens, 8 and 10 inches in lengtb respectively, from Tsiltcoos Lake near outlet, December 2, 1896 . Back, brownish blue; dorsal, nearly black, larker on posterior part; pectorals, light brownish; veutrals, white; anal fin with a dark shade. These specimens were probably hatcherl during the winter of 1894-95.

Trwo specimeus from Seattle, Washington, $10 \frac{1}{2}$ inches in length. 
Six mature specimens from Union Lake near Seattle, Washington, 4 males and 2 females. Of the small specimens, no doubt hatched during the winter of 1895-96, our collection contains the following:

Two specimens, $2 \frac{7}{3}$ and $3 \frac{1}{2}$ inclies in leugth respectively, hatched during the winter of $189.5-96$ by Mr. L. E. Bean at Mapleton and retainol in a small spring brook until September 9, 1896.

One, 3 inches long, canght in a seine in Siuslaw River below Florence December 8, 1896.

Two specimens, $5 \frac{1}{5}$ aud $5 \frac{8}{5}$ inches respectively, caught with a seine in Tsiltcoos Lake December 1 , 1896. All three with parr marks present; no red on sirles; dorsal, adjpose, and caudal fius yellowish; caudal rerldish near tips; pectoral and rentrals yellowish.

During the latter part of September and early part of October Mr. Alexauder was at Celilo, on the Columbia River, and made some valuable observations unon the silver salmon. He examined a total of 2,268 fish of this species, all of which he found well advanced, indicating to him that they would spawn before the midule of October.

Silver salmon examined by Mr. Alexander at Celilo.

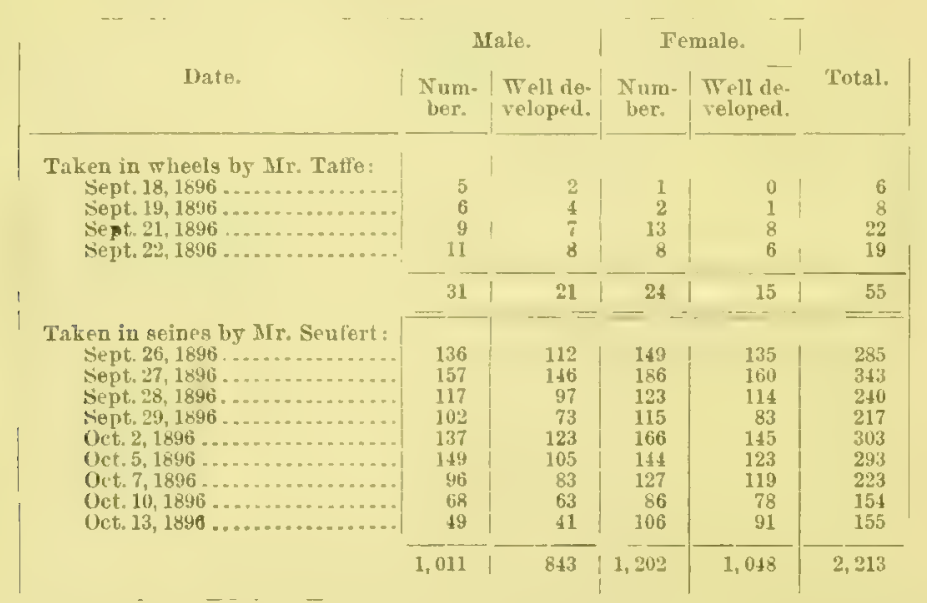

Silver salmon first appenr in the southern end of Pnget Sonnd about the 1st of September, and the run usually lasts until the first or middle of November. A few individuale are taken as late as December, after which few are seen in the sound, bnt a good many are caught in Duwamish River.

23. Oncorhynchus nerka (Walbaum). lilueback Salmon; "ledfish"; "Sockeye."

The investigations male in Ilaho in 1891 and 1895 resulted in settling some of the disputed questions concerning the redfish, but left others still in doubt. The details of the olsservations made in those years will be found in the reports already published.* A summary of the conclusions reached regarding the life-history of the redifs is given on page 16 of this article.

Although no satisfuctory evidence was obtained as to the occurrence of the small form anywhere in the stream below the lakes, this was not considered proof that it does not come up from the sea. So close is its resemblance to the native trout, except at spawning time, that it would probably not attract the attention of anyone, eren if seen below the lakes.

In order to obtain more definite results in the stuly of this problem, the redtish lakes of Idaho were again visited in 1896. Camp was established July 11, on Alturas Lake Creek at the crossing of the trail a short distance luelow I'erkins Lake. Gill nets were set in the outlet the same day and were kept set until September 25. These nets were examined from tay to day during the entire period of seventy six dags and not a single redish was caught in them. The water was so high aud the current so swift during the first ten days the nets were set that it was impossible to place them so as to wholly obstruct the strean. It is therefore possible that fish may have ascender the strean and passel the nets

* A Preliminary lieport upon Salmon Investigations in Idalo in 1894, by Barton W. Evermann, Bull. U. S. F. C. $189 \pi, 253-284$.

A lieport upon Salmon Investigations in the Headwaters of the Columbia River, in the State of Italuo, iu 1895; together with Notes upon the Fishes observed in that State in 1894 and 1895, by Barton W. Evermann, Bull. U.S. F. C. 1896, 149-202, plates 67-72. 
during that time. This, however, is improbable. Our camp was situated npon the bank of the stream, the water was at all times very clear, and we were able to keep close watch for fish. If any redrish had come up during those ten days it is more than probalile they would have been seen by some of us. After July 22 these nets were examined usually about three times each week, and though othor fishes, such as yellowbellies, Dolly Varien trout, suckers, and whitefish, were caught by them, no redfish, either large or small, were taken. But small redfish were in the lake at least as early as Julj 16 , and they began entering the inlet August 3. Between August 3 and August 28 the number in the inlet increased rapidly until the latter date, when 1,569 were counted.

The first small redfish seen was caught on a hook in Alturas Lake, just off the inlet, July 16 , by Mr. Maddren, while fishing for Dolly Varlen trout. The hook was baited with salmon spawn. This fish was a male $11 \frac{1}{2}$ inches in total length, and the stomach contained a small amount of insect larvr. Of the many examples, taken by a gill net in Alturas Inlet on August 6, 9 were examined, only one of which showed any trace of food in the stomach.

Trelve specimens, caught with grab-hook in. Wallowa Lake about the 1 st of September by Mr. J. J. Stanley, were all quite fat, and food was found in the stomachs of all but three. This food consisted chietly of small crustaceans, in fow insect larva, and some gelatinous alga, probably a Nostoc.

Amoug the fishes from Lake Washington are 5 reltish, 3 of which are 7 to 8 inches long, the other 2 about 4 inches each. These were all collected June 15 by Mr. Alexander. Each contains more or less food in the stomach. Two other small redfish were obtained, which bad been taken on the tly by Mr. E. L. Kellogg whilo fisbing in Lake Sammamish about May 15.

Whether this fish is anadromous or not is an exceedingly difficult matter to determine. If it comes up from the sea it reaches the lakes much earlier in the summer or spring that has hitherto been supposed. The fact that it feeds while in the lakes is now full 5 established, and it apparently continues to feed almost or quite to the time when it runs into the inlets for spawning. 'The one with food in its stomach, taken in Alturas Inlet August 6, hal just reached the inlet on that night. The specimens from Wallowa Lake were caught in the upper end of the lake near the inlet, which they doubtless would have ascended in a few dass.

A consideration of small redfish from different localities, as to their size, prores interesting and suggestive. Those from Alturas Lake are larger and much more uniform in size than those from other places. Those from Washington, Stuart, and Nicula lakes are somerhat smaller, while those from Wallowa Lake are much smaller. These difierences in size are, in some cases, doubtless due to differences in age, the specinens having been taken earlier at some of the lakes than at others, but the marked difference between the Alturas and Wallowa specimens can not be accounted for on this basis. It is doubtful if any of the Wallowa individuals would have reached even the minimum size of those taken at Alturas Lake. This fact is brought out in the following table. In the first column are giren lengths in inches, the length being measured to the tip of the candal fin; in the othur columns are given the number of fish of each length from the respective lakes named at the head of the columns.

Table showing comparative sizes of specimens of the small redfish from different lakes.

\begin{tabular}{|c|c|c|c|c|c|c|c|}
\hline \multirow[b]{2}{*}{$\begin{array}{l}\text { Length } \\
\text { in inches. }\end{array}$} & \multirow[b]{2}{*}{ Alturas. } & \multirow[b]{2}{*}{ Wallowa. } & & & \\
\hline & & & $\begin{array}{l}\text { Washing. } \\
\text { ton. }\end{array}$ & Stewart. & Sicola. & $\begin{array}{l}\text { Chilorey- } \\
\text { uck. }\end{array}$ & $\begin{array}{c}\text { Total } \\
\text { number. }\end{array}$ \\
\hline 7. 100 & & $\because$ & & 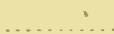 & & & 2 \\
\hline$\therefore 06$ & . $\ldots \ldots \ldots$ & 1 & & & & & $i$ \\
\hline 8.25 & ............ & 1 & & ....... & & $\ldots \ldots \ldots \ldots$ & 1 \\
\hline 850 & $\ldots \ldots \ldots$ & 1 & $\ldots \ldots \ldots$ & & 1 & $\ldots \ldots \ldots \ldots$, & 4 \\
\hline $\begin{array}{l}87.5 \\
7.4111\end{array}$ & $\ldots \ldots \ldots$ & 1 & n. & $3^{\cdots}$ & 1 & …....... & $\frac{2}{3}$ \\
\hline 9.25 & & & 1 & & & & $i$ \\
\hline y. . 10 & . & 1 & $\ldots$ & ........... & 1 & & 2 \\
\hline 9.75 & & ....... & 3 & $\ldots \ldots \ldots$ & " & .... . & 5 \\
\hline 111. 611 & & & \pm & 1 & ...... & $\ldots \ldots \ldots$ & 5 \\
\hline 10.27 & 4 & $\begin{array}{lll}\ldots \ldots & \ldots \\
\cdots\end{array}$ & 5 & 1 & . & ........ & 10 \\
\hline 10. 50 & 4 & & 4 & .. & .... & 2 & 10 \\
\hline 111. 75 & 6 & & & ... & $\ldots$. & . $\ldots \ldots \ldots$ & 6 \\
\hline 11. 111 & $\because$ & $\ldots$ & $\cdots \cdots \cdots$ & $\ldots \ldots \ldots$ & $\ldots \ldots$ & $\ldots \ldots \ldots$ & 9 \\
\hline $\begin{array}{ll}11 & 25 \\
11 & 54\end{array}$ & 1.3 & & & $\cdots$ & $\cdots \cdot \cdot$ & .............. & 15 \\
\hline 11.90 & $\begin{array}{l}\because 1 \\
\vdots 11\end{array}$ & & & . & 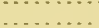 & $\cdots$ & $\begin{array}{l}313 \\
\because 11\end{array}$ \\
\hline $1 \geq 0$ & 19 & 0 & ... & ........ & ....... & ...... & 1! \\
\hline $12.2 \pi$ & 6 & & 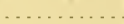 & $\ldots \ldots$ & .... & & 6 \\
\hline \multirow[t]{2}{*}{1250} & $t$ & & & ....... & $\ldots \ldots \ldots$ & $\ldots \ldots \ldots$ & 4 \\
\hline & $1: 0$ & 11 & 17 & 4 & $t$ & 2 & 161 \\
\hline
\end{tabular}


Table of comparative measurements of small redfish from Llluras and Tallowa lakes.

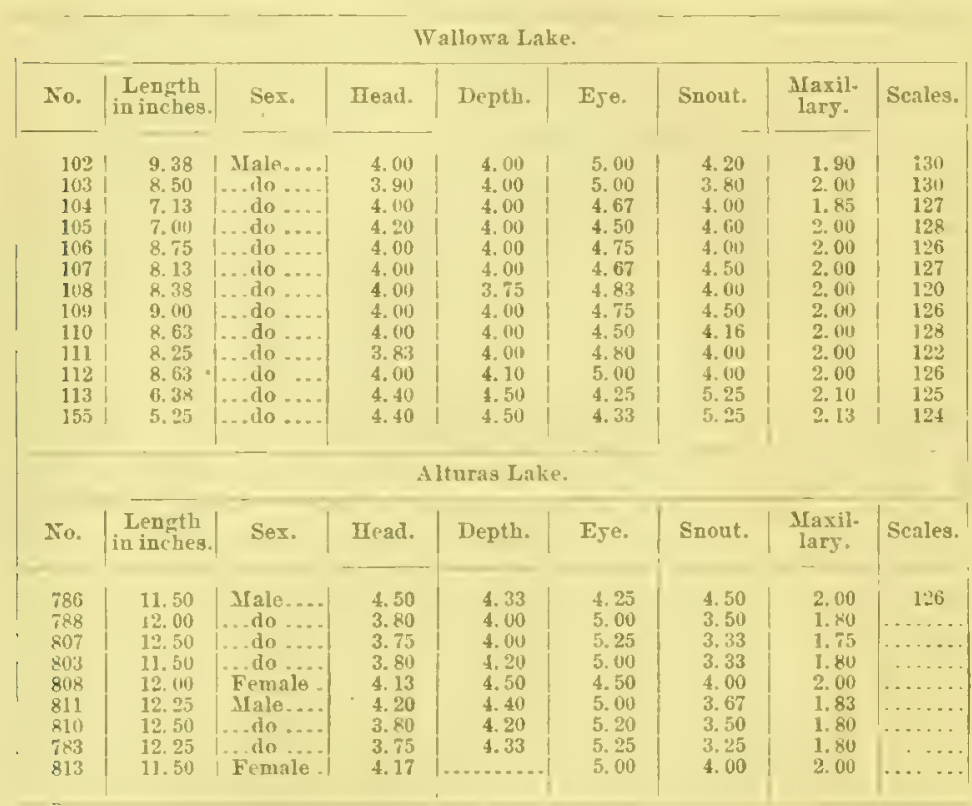

Specimen Nio. 155 was found dead on the shore at head of lake; specimens Nos. 113 and 155 with undereloperl sexual organs.

24. Salvelinus malma (Walbanm). Dolly Tarden Trout; Western Charr; Bull Trout.

Obtainel in Alturas, Pend d'Oreille, and Wallowa lakes, where it is abundant and affords goor sport for the angler. At Alturas Lake during July a great many were ciught alout the mouth of the inlet and many large examples trere taken in Lake Pend d'Oreille. The charr is a roracious fish and jreys Jargely upon other species of fishes. In the stomachs of some of those examined at Lake Pend d'Oreille were unmerous specimens of Leuciscus baltealus, P'ychocheilus oregonensis, Mylocheilus caurinus, aut Cotfus. All of thesce except $M$. caurinus were found in the stomach of one fish. Some specimens from this lake were infested about the axils by a small crustacean of the genus Lernacopoda.

Measurements of a number of specimens of charr are given in the following table:

Comparatice measurements of charr from the Columbia liver Basin.

\begin{tabular}{|c|c|c|c|c|c|}
\hline $\begin{array}{l}\text { Length in } \\
\text { inches. }\end{array}$ & Head. & Depth. & Eje. & Snout. & Maxillary. \\
\hline $\begin{array}{r}a 12.50 \\
a 18.50 \\
b 12.25 \\
e 6.50 \\
c 5.50 \\
d 11.50 \\
d 10.50 \\
d 10.50 \\
d 11.00\end{array}$ & $\begin{array}{l}3.80 \\
3.40 \\
3.83 \\
4.20 \\
4.00 \\
4.00 \\
4.00 \\
3.83 \\
3.75\end{array}$ & $\begin{array}{l}4.80 \\
6.00 \\
5.00 \\
5.00 \\
4.75 \\
5.50 \\
6.00 \\
6.00 \\
6.00\end{array}$ & $\begin{array}{l}6.40 \\
7.50 \\
6.60 \\
5.25 \\
5.00 \\
7.00 \\
6.00 \\
6.00 \\
6.00\end{array}$ & $\begin{array}{l}4.00 \\
3.00 \\
3.60 \\
4.00 \\
4.00 \\
3.83 \\
3.83 \\
3.83 \\
4.00\end{array}$ & $\begin{array}{l}2.00 \\
1.60 \\
1.85 \\
1.85 \\
2.00 \\
2.00 \\
2.00 \\
2.00 \\
2.00\end{array}$ \\
\hline
\end{tabular}

a From Alturas Lake, Idaho. c From Wallowa Lake, Oregon.

b From Little White Salmon IRirer, Washington. d From Lake Pend d'Oreille. Idabo.

25. Salmo mykiss clarkii Richardson. American Cut-throat Trout.

Numerous specimens obtained. Particularly abundant in Lake Washington, Siuslaw River, and the lakes near its mouth, Wallowa and Alturas lakes, Upper Klamath Lake, and in Des Chutes River. A comparison of many specimens indicates that it will be necessary to recognize wore species or varieties of Salmo in the northwestern portion of the United States than have hitherto been admitted; but it seems best to hold the matter open for alditioual data and cousideration.

$$
\text { F. C. B. 1897-6 }
$$


26. Salmo gairdneri Richardson, Steelhead Trout; "Salmon Trout."

Seen in large numbers at Astoria and The Dalles. Not common in the Siuslaw, and only 2 specimens obtained in Upper Klamath Like. While at The Dalles during the last week in September and the tirst half of October Mr. Alexander examined 4,179 steelheads, of these, 1,531 were males and 2,648 females; 476 males, and 900 females were well dereloped, and would probably have spawned in four to six weeks. The remaining 2,803 , he thinks, would not hare spawned until some time in the spring.

Steelhead salmon taken by $16 r$. I. H. Taffe, at Celilo, September 18 to $2 \%, 1806$, and examined by Mr. Alexander.

\begin{tabular}{|c|c|c|c|c|c|c|c|}
\hline \multirow[b]{2}{*}{ Date. } & \multicolumn{2}{|c|}{ Male. } & \multicolumn{2}{|c|}{ Female. } & \multirow[b]{2}{*}{ Total. } & \multicolumn{2}{|c|}{ How caught. } \\
\hline & Number. & $\begin{array}{l}\text { Well de- } \\
\text { reloped. }\end{array}$ & Number. & $\begin{array}{l}\text { Well de- } \\
\text { veloped. }\end{array}$ & & $\begin{array}{c}\text { In } \\
\text { wheet. }\end{array}$ & $\begin{array}{c}\text { By } \\
\text { spear. }\end{array}$ \\
\hline \multirow[t]{2}{*}{$\begin{array}{l}\text { Sept. } 18,1896 \ldots \ldots \ldots \ldots \ldots \ldots \\
\text { Sept. } 19,1896 \ldots \ldots \ldots \ldots \ldots \ldots \\
\text { Sept. } 21,1896 \ldots \ldots \ldots \ldots \ldots \ldots \\
\text { Sept. } 22,1806 \ldots \ldots \ldots \ldots \ldots \ldots\end{array}$} & $\begin{array}{l}111 \\
130 \\
121 \\
159\end{array}$ & $\begin{array}{l}10 \\
28 \\
29 \\
59\end{array}$ & $\begin{array}{l}124 \\
110 \\
366 \\
391\end{array}$ & $\begin{array}{r}15 \\
22 \\
98 \\
164\end{array}$ & $\begin{array}{l}235 \\
240 \\
487 \\
550\end{array}$ & $\begin{array}{l}160 \\
180 \\
192 \\
350\end{array}$ & $\begin{array}{r}75 \\
60 \\
295 \\
200 \\
\end{array}$ \\
\hline & 521 & 126 & 991 & 299 & 1,512 & 882 & 630 \\
\hline
\end{tabular}

Steelhead salmon taken in seines by Mr. F. A. Senfert, at Celilo, September 25 to October 19, 1896.

\begin{tabular}{|c|c|c|c|c|c|}
\hline \multirow[b]{2}{*}{ Date. } & \multicolumn{2}{|c|}{ Male. } & \multicolumn{2}{|c|}{ Female. } & \multirow[b]{2}{*}{ Total. } \\
\hline & Number. & $\begin{array}{l}\text { Well de- } \\
\text { reloped. }\end{array}$ & Number. & $\begin{array}{l}\text { Well de- } \\
\text { veloped. }\end{array}$ & \\
\hline 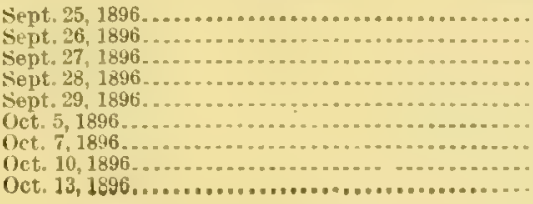 & $\begin{array}{r}129 \\
148 \\
218 \\
97 \\
176 \\
49 \\
116 \\
46 \\
31\end{array}$ & $\begin{array}{l}22 \\
28 \\
91 \\
44 \\
77 \\
12 \\
49 \\
12 \\
15\end{array}$ & $\begin{array}{r}296 \\
281 \\
328 \\
140 \\
231 \\
50 \\
181 \\
81 \\
66\end{array}$ & $\begin{array}{r}103 \\
112 \\
140 \\
48 \\
72 \\
14 \\
60 \\
21 \\
31\end{array}$ & $\begin{array}{r}425 \\
429 \\
546 \\
237 \\
410 \\
99 \\
297 \\
127 \\
97\end{array}$ \\
\hline & 1,010 & 350 & 1,657 & 601 & 2,667 \\
\hline
\end{tabular}

Mr. Alexander states that not many steelhead are seen about Seattle until the latter part of Norember or earl 5 in December, or about two months after they begiu running up the rivers at the northern end of the sound. During tbe early part of January, 1897, a gool many were taken near Seattle. They were considered equal in quality to those taken in other parts of the sound. Their eggs were in varions stages of development; a few fish were spent, but the majority were well adranced and would have spawned in a short time.

27. Hypomesus pretiosus (Girard).

Nineteen specimens from Siuslaw River at Florence, where it is abuudant about the cannery wharf luring the canning season.

28. Gasterosteus cataphractus (Pallas). Alaska Stickleback.

Found in Sinslaw River at Florence and at mouth of the outlet of Tsiltcoos Lake. Only a few specimens were obtained.

29. Gasterosteus williamsoni microcephalus (Girard). California Stickleback.

Mauy specimens from Tsiltcoos Lake, in which it is quite abundant. A few specimens were oltained in Lake Washington by Mr. Alexander, where it was also obtained in 1892.

30. Siphostoma griseolineatum (Ayres). Nipefish.

One specimen, $10 \frac{8}{3}$ inches in length, from the Siuslaw River near Point Terrace. It was caught in a 7-inch-mesh salmon gill net.

31. Ammodytes personatus Girard. Sand Lance.

One specimen, 3 inclies in length, from the Siuslaw River at Florence. Dorsal 60; aual 26.

32. Cymatogaster aggregatus Gibbons.

A Cottus which we with some hesitation refer to this species is very abundant in Siuslaw River about the cannery wharf luring the canning season. 
33 Cottus asper Richardson. Prickly Bullhead.

Nine small specimens collected in Lake Washington, June 15. Head nearly or quite naked, but entire body except belly uniformly covered with small prickles.

\section{Cottus gulosus (Girard)}

A Cottus which we with some hesitation refer to this species is very abundant in fresh and brackish waters in Siuslaw River and in the lakes south of Florence, and easily caught on a trawl, or with hook and line. Mapleton, Oregon, Sinslaw River, 25 specimens; Acme, Oregon, South Slough, 4; Whoahink Lake, 3; Tsilteoos Lake, 20; Tahkenitch Lake, 9; Lake Washington, 1; Lake Sammamish, 2.

\section{Cottus punctulatus (Gill).}

One specimen, 2.75 inches long, obtained from the stomach of a bull trout, Alturas Lake, July 16, 1896. Five from Alturas Lake, July 30, 1896.

\section{Cottus princeps Gilbert.}

Cottus princeps Gilbert, Bull. U. S. F. C. 1897, 12, with figure.

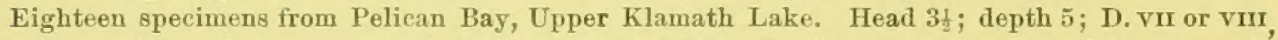

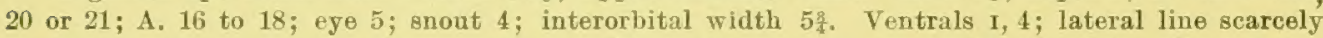
complete; anterior portion of body covered with prickles; posterior part smooth below. Head rather long, pointed; maxillaries reaching to front of pupil. Color same as in C. leiopomus, which it closely resembles, but from which it differs in the more numerous dorsal and anal rays, the shorter snout, somewhat broader interorbital, and in having the body covered with prickles.

\section{Cottus klamathensis Gilbert.}

Cottus klamathensis Gilbert, Bull. U. S. F. C. 1897, 10, with figure.

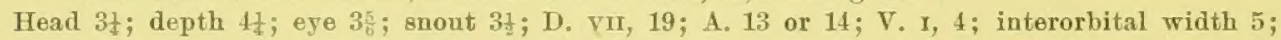
maxillary reaching front of pupil. No teeth on palatines; a single straight preopercular spine, appar. ently disappearing in older examples; nostril in distinct tubes; body short, stout; head moderately broad, wedge-shaped anteriorly; caudal peduncle short, compressed, its greatest width 2 in eye, least depth 1-in eye; gill membranes joined to the isthmus, widely separated; body smooth. Color rather light; body with about 10 obscure irregular vertical blotehes, but everywhere covered with minuet lrown spots, a V-shaped bar at base of caudal; spinous dorsal with a dark bloteh on its posterior inition; soft dorsal profusely covered with fine black specks; caudal faintly barred with dark and lighter. A siugle small example from the lower end of Upper Klamath Lake.

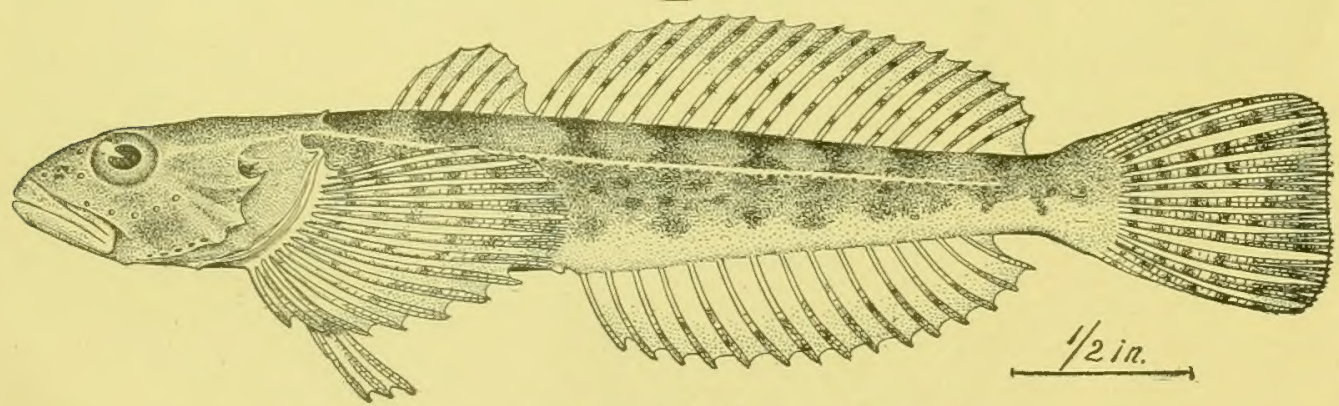

FIG. 6.-Uranidea tenuis Fvermann \& Meek, new species.

38. Uranidea tenuis, new species.

Type No. 48229, U. S. N. M. ; cotypes No. 5705, L. S. Jr. Univ. Mus., and No. 434, U. S. F. C. Type locality: Lower end of Upper Klamath Lake, near Klamath Falls, Oregon, November 10, 1896. Collectors Meek and Alexander.

Length of type, 3 inches, or 35 inches including candal. Apparently allied to Vranidea marginata.

Head 35 ; depth 7 ; eye $4 \frac{1}{2}$; snout 4 ; V. I, 3; D. VI-I, 17; A. 15. Vomer with teeth; palatines toothless. Head long, contracted from eyes forward; snout rather long; body much compressed, very slender; greatest width of caudal peduncle $2 \frac{1}{2}$ in eje; least depth of same slightly greater than eye; preopercular spine well developed, broad, rather sharp, partly covered by skin, curved upward; below this two other spines, the anterior one blunt, the other sharp, directed toward lower base of pectoral; post-temporal spine well developed. Body smooth, wholly without prickles or scales; lateral line complete except on caudal peduncle. 
Color, dark above and on upper three-fourths of sides, pale below; dorsal fins barred with series of dark dots or blotches; caudal similarly marked but rather darker; anal light with a few dark blotches; pectorals same as caudal; ventrals plain; under side of head profusely covered with small, round black specks; muciferous pores on head well developed.

Besides the specimen described above we have two others of the same slender style from Peliean Bay, and many others from Pelican Bay, the majority of which are mueh smaller and less slender. The slender ones are apparently entirely smooth; a ripe female 3 inches loug has a few prickles on anterior part of body, while all the smaller ones are pretty well covered with small prickles.

39. Leptocottus armatus Girard

Very abundant in Sinslaw River below Acme and easily caught on a trawl or with hook and line.

40. Platichthys stellatus Pallas. California Flounder.

Common about the mouths of Siuslaw River and Ten Mile Creek; occasionally taken during the summer as far up the river as Mapleton. Of 11 specimens from Siuslaw River and Ten Mile Creek, 6 are dextral and 5 are sinistral. 

LIBRARY OF CONGRESS

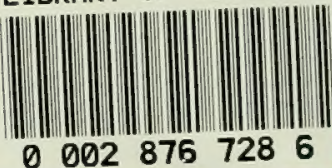

